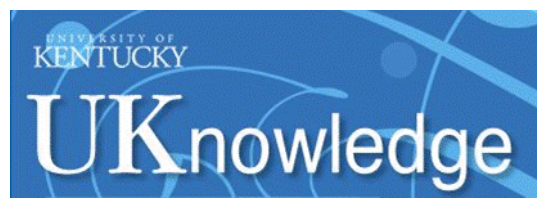

University of Kentucky

UKnowledge

Theses and Dissertations--Earth and Environmental Sciences

2019

\title{
VARIABILITY IN GROUNDWATER FLOW AND CHEMISTRY IN THE HOUZHAI KARST BASIN, GUIZHOU PROVINCE, CHINA
}

Joshua M. Barna

University of Kentucky, josh.m.barna@gmail.com

Author ORCID Identifier:

(iD) https://orcid.org/0000-0003-0041-0811

Digital Object Identifier: https://doi.org/10.13023/etd.2019.109

Right click to open a feedback form in a new tab to let us know how this document benefits you.

\section{Recommended Citation}

Barna, Joshua M., "VARIABILITY IN GROUNDWATER FLOW AND CHEMISTRY IN THE HOUZHAI KARST BASIN, GUIZHOU PROVINCE, CHINA" (2019). Theses and Dissertations--Earth and Environmental Sciences. 65.

https://uknowledge.uky.edu/ees_etds/65

This Master's Thesis is brought to you for free and open access by the Earth and Environmental Sciences at UKnowledge. It has been accepted for inclusion in Theses and Dissertations--Earth and Environmental Sciences by an authorized administrator of UKnowledge. For more information, please contact UKnowledge@lsv.uky.edu. 


\section{STUDENT AGREEMENT:}

I represent that my thesis or dissertation and abstract are my original work. Proper attribution has been given to all outside sources. I understand that I am solely responsible for obtaining any needed copyright permissions. I have obtained needed written permission statement(s) from the owner(s) of each third-party copyrighted matter to be included in my work, allowing electronic distribution (if such use is not permitted by the fair use doctrine) which will be submitted to UKnowledge as Additional File.

I hereby grant to The University of Kentucky and its agents the irrevocable, non-exclusive, and royalty-free license to archive and make accessible my work in whole or in part in all forms of media, now or hereafter known. I agree that the document mentioned above may be made available immediately for worldwide access unless an embargo applies.

I retain all other ownership rights to the copyright of my work. I also retain the right to use in future works (such as articles or books) all or part of my work. I understand that I am free to register the copyright to my work.

\section{REVIEW, APPROVAL AND ACCEPTANCE}

The document mentioned above has been reviewed and accepted by the student's advisor, on behalf of the advisory committee, and by the Director of Graduate Studies (DGS), on behalf of the program; we verify that this is the final, approved version of the student's thesis including all changes required by the advisory committee. The undersigned agree to abide by the statements above.

Joshua M. Barna, Student

Dr. Alan E. Fryar, Major Professor

Dr. Edward Woolery, Director of Graduate Studies 


\section{VARIABILITY IN GROUNDWATER FLOW AND CHEMISTRY IN THE HOUZHAI KARST BASIN, GUIZHOU PROVINCE, CHINA}

\section{THESIS}

A thesis submitted in partial fulfillment of the requirements for the degree of Master of Science in the College of Arts and Sciences at the University of Kentucky

By

Joshua M. Barna

Lexington, Kentucky

Director: Dr. Alan E. Fryar, Associate Professor of Earth and Environmental Sciences Lexington, Kentucky 2019

Copyright (C) Joshua M. Barna 2019 


\section{ABSTRACT OF THESIS}

\section{VARIABILITY IN GROUNDWATER FLOW AND CHEMISTRY IN THE HOUZHAI KARST BASIN, GUIZHOU PROVINCE, CHINA}

Understanding how karst aquifers store and transmit water and contaminants is an ongoing problem in hydrogeology. Flowpath and recharge heterogeneity contribute to the complexity of these systems. This thesis explores karst-conduit connectivity and water chemistry variability in the Houzhai catchment in Guizhou province, China. Artificial tracer tests were conducted during both the monsoon and dry seasons to understand temporal variability in connectivity and water velocity between karst features. Multiple flowpaths through the catchment are activated during the monsoon season and partially abandoned during the dry season. Additionally, gradient reversals during monsoonal high-flow events and as a result of pumping can be significant. Synoptic water samples from several karst features taken during both monsoon and dry seasons elucidate spatial and temporal variability within the catchment. In general, water residence time is longer during the dry season and flow within the Houzhai catchment is temporally dependent. Time-series sampling at the outlet spring during a monsoonal storm event captured chemical variability and identified multiple flowpaths. Overall, this study refines widely applicable methods for studying karst systems to this catchment and provides a foundation for future studies in similar settings.

KEYWORDS: Karst, Hydrogeology, Stable Isotope, Geochemistry, Dye Trace, China

Zoshea IM Barna

Joshua M Barna

$04 / 24 / 2019$

Date 
VARIABILITY IN GROUNDWATER FLOW AND CHEMISTRY IN THE HOUZHAI KARST BASIN, GUIZHOU PROVINCE, CHINA

By

Joshua M. Barna

Alan E. Fryar

Director of Thesis

Edward Waolery

Director of Graduate Studies

$04 / 24 / 2019$

Date 


\section{ACKNOWLEDGMENTS}

I would like to begin by thanking Dr. Alan Fryar, not only for bringing me to Kentucky to work on this project, but also for being an incredible mentor and friend. I have learned so much and believe I have grown as a person under your guidance and through our experiences together. For this I am immensely grateful. Thank you Dr. Andrea Erhardt, Dr. Junfeng Zhu, and Dr. Chen Zhu for your support throughout this project and for serving as members on my committee. Your input and guidance through every step of this project have strengthened it immeasurably.

Next, I want to thank Dr. Tao Peng for his collaboration on this project and exceeding generosity in inviting Alan and me to China. This project would not have been possible without the daily help in the field from Cao Le and Driver Song. Many thanks to Guanru Zhang, Qianyun Cheng, Sarah Buckerfield, Qiangshan Gao, Xuemei Liu, and Yang Changan for their support in the field as well. Thank you to Dr. Zhikang Wang, his students, and Guizhou Minzu University for their collaboration in helping us look for dye in our samples in China.

Back at home, I would like to thank Ben Currens for his support in getting me into this project, for helping me to prepare to go to China, and for helping me to look for dye using the spectrofluorometer. Also thank you to Amanda Sherman and Cris Alvarez for their support as labmates and friends. Thanks to Andrea Conner at KGS for the use of her lab and spectrofluorometer. Thank you to Jordan Munizzi and the Kentucky Stable Isotope Geochemistry Laboratory for his support and help running the $\delta^{18} \mathrm{O}$ and $\delta^{2} \mathrm{H}$ water samples. I want to thank Jim Currens for helping us in planning our dye injections. 
Thank you to Christopher J. Matocha and Martin VanDiviere for helping us rerun some of our anion samples. Thanks to the University of Kentucky Applied Statistics Laboratory for their help in performing statistical analyses.

Finally, I would like to thank my family for being infinitely supportive of me these past two years. I would have never gotten to where I am now without your faith and love. Thank you, Rebecca, for helping me through this entire process, your support has meant the world to me.

I gratefully acknowledge funding from the University of Kentucky Ferm and Brown McFarlan funds, the University of Kentucky Confucius Institute, and the Chinese Academy of Sciences Institute of Geochemistry. 
TABLE OF CONTENTS

ACKNOWLEDGMENTS .....................................................................................ii

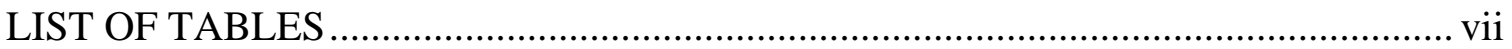

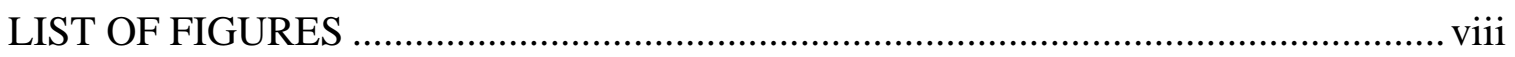

CHAPTER 1. Introduction........................................................................................... 1

$1.1 \quad$ Previous Research .............................................................................. 4

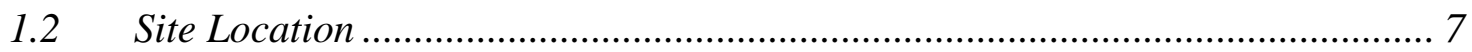

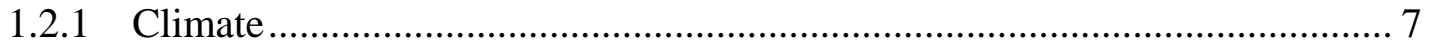

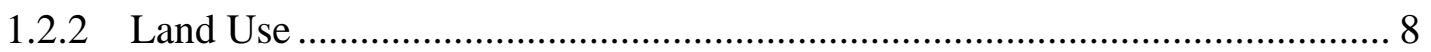

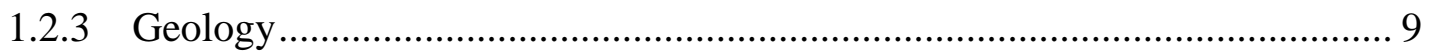

1.2.4 Hydrogeology ………………………………....................................... 13

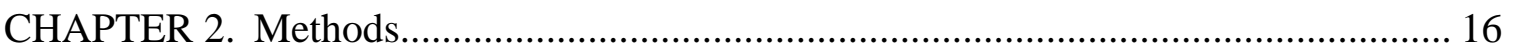

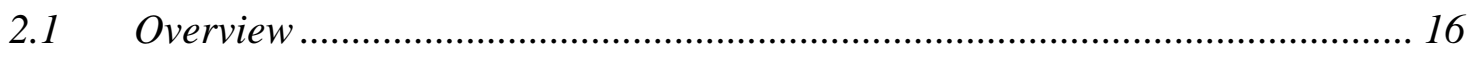

2.2 Synoptic Sampling and Continuous Logging................................................... 16

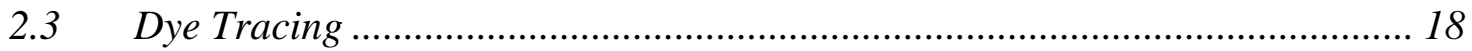

2.3.1 Passive Dye Sampling............................................................................ 18

2.3.2 Summer Baseflow Trace.......................................................................... 20

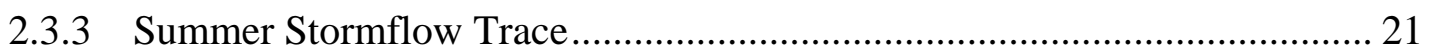

2.3.4 Winter Baseflow Traces.......................................................................... 22

2.3.5 Bug/Dye Testing ..................................................................................... 23

$2.4 \quad$ Solute and Isotope Analyses.......................................................................... 25

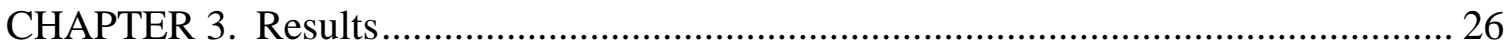

3.1 Synoptic Sampling.......................................................................................... 26

3.2 Time-Series Analysis............................................................................... 36

3.3 Dye Tracing ............................................................................................... 49

3.3.1 Summer Baseflow Trace......................................................................... 49

3.3.2 Summer Stormflow Trace.......................................................................... 52

3.3.3 Winter Baseflow Traces............................................................................. 54

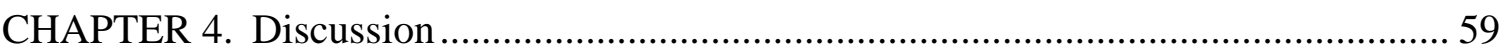

4.1 Controls on Solute and Isotope Chemistry ………........................................... 59

4.1.1 Synoptic Sampling Data ........................................................................... 59 


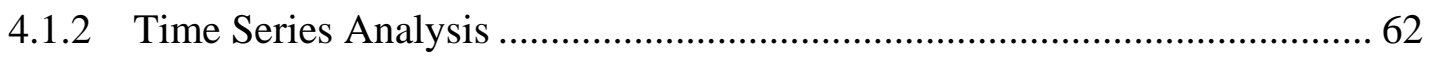

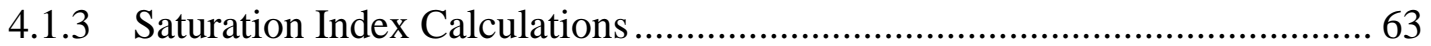

4.2 Inferences about Network Connectivity and Groundwater Flow from Tracers 69

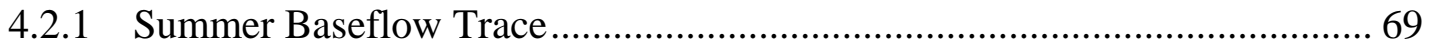

4.2.2 Summer Stormflow Trace ................................................................... 71

4.2.3 Winter Baseflow Traces.................................................................... 72

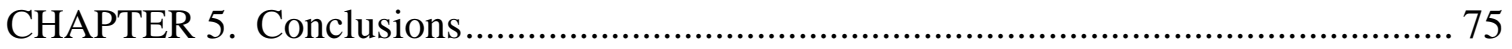

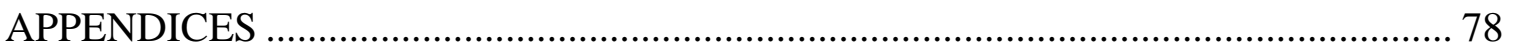

APPENDIX A. Field Activity and Conduit Distances.............................................. 78

APPENDIX B. Field Parameter and Synoptic Sample Data ..................................... 81

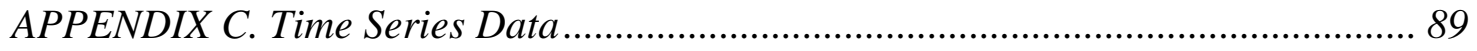

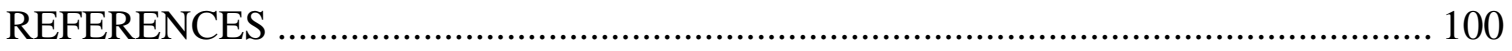

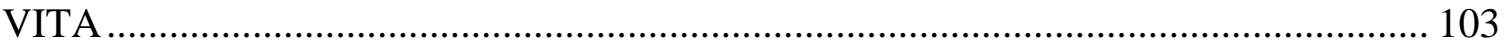




\section{LIST OF TABLES}

Table 1: Ranges of summer and winter synoptic sample field parameters and analytes.. 27

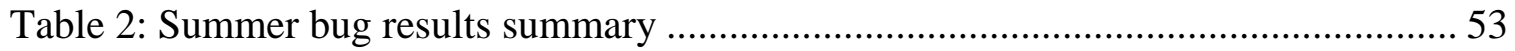

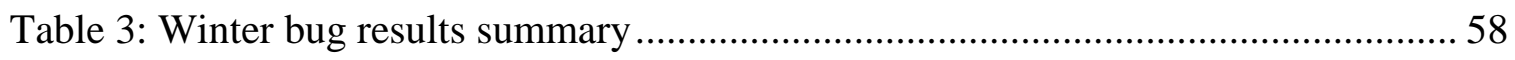

Table 4: Ranges of calculated summer and winter synoptic sample saturation indices ... 63

Table 5: Summary of flow velocities under different hydraulic conditions .................... 73 


\section{LIST OF FIGURES}

Figure 1: Context map of China............................................................................ 2

Figure 2: Houzhai catchment map with monitored karst features ................................... 2

Figure 3: Triangular irregular network (TIN) of the Houzhai catchment........................ 11

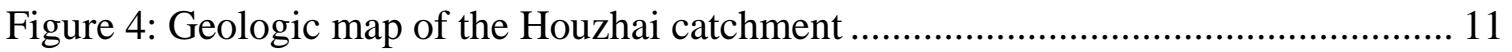

Figure 5: Geomorphic classification map of the Houzhai catchment............................. 12

Figure 6: Location of the Chenqi subcatchment within the Houzhai catchment .............. 12

Figure 7: Comparison of two field photographs of Aliangzhai ..................................... 13

Figure 8: Comparison of two field photographs of Daxing........................................... 14

Figure 9: Comparison of two field photographs of Liugu ............................................. 14

Figure 10: Comparison of two field photographs of Tian Guan...................................... 15

Figure 11: Images of charcoal bugs used to record the presence of dye .......................... 18

Figure 12: Field photographs of summer salt injection and baseflow dye injection ........ 21

Figure 13: Field photograph showing summer stormflow dye injection......................... 22

Figure 14: Field photographs showing winter baseflow dye injections ......................... 23

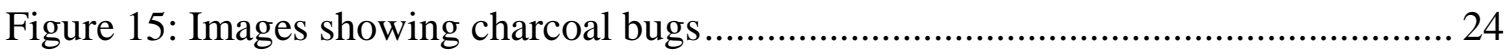

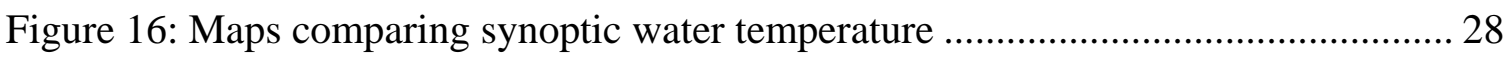

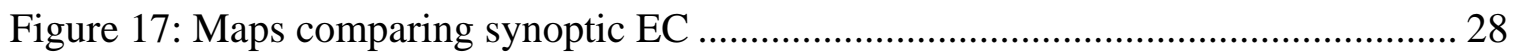

Figure 18: Maps comparing synoptic water sample $\mathrm{pH}$.............................................. 29

Figure 19: Maps comparing synoptic water sample carbonate alkalinity........................ 29

Figure 20: Maps comparing synoptic water sample $\mathrm{Mg} / \mathrm{Ca}$ ratio .................................... 30

Figure 21: Maps comparing synoptic water sample $\delta^{13}$ CDIC values .............................. 30

Figure 22: Maps comparing synoptic water sample $\delta^{2} \mathrm{H}$ values .................................. 31

Figure 23: Maps comparing synoptic water sample $\delta^{18} \mathrm{O}$ value values .......................... 31

Figure 24: Piper diagram plotting summer and winter synoptic samples........................ 32

Figure 25: Piper diagram plotting summer synoptic samples, winter synoptic samples,

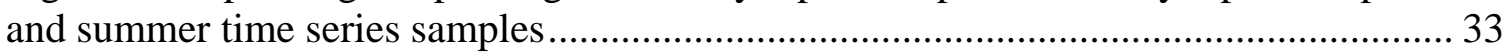

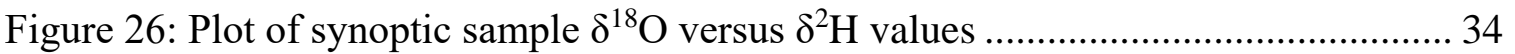

Figure 27: Plot of synoptic sample and time-series $\delta^{18} \mathrm{O}$ versus $\delta^{2} \mathrm{H}$ values ................... 35

Figure 28: Plot of synoptic sample, time-series, and Chen et al. (2018) $\delta^{18} \mathrm{O}$ versus $\delta^{2} \mathrm{H}$

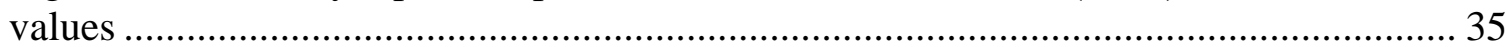

Figure 29: Plot showing relative water level data from Laoheitan, Daxing, and

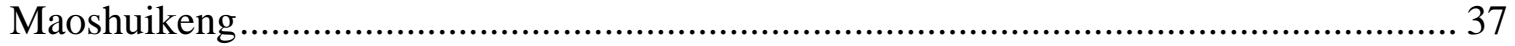

Figure 30: Plot showing electrical conductivity data from Laoheitan, Daxing, and

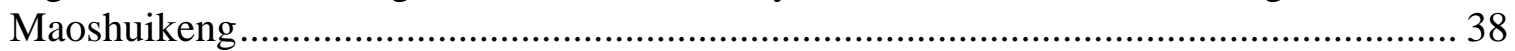

Figure 31: Plot showing temperature data from Laoheitan, Daxing, and Maoshuikeng .. 38

Figure 32: Plot showing EC and water level at Maoshuikeng...................................... 39

Figure 33: Plot showing water level and precipitation at Maoshuikeng.......................... 39

Figure 34: Plot showing electrical conductivity during time series sampling ................. 40

Figure 35: Plot showing water temperature during time series sampling....................... 40 


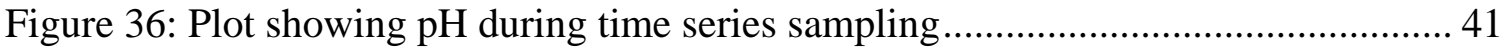

Figure 37: Plot showing carbonate alkalinity during time series sampling ..................... 41

Figure 38: Plot showing fluoride concentration during time series sampling ................. 42

Figure 39: Plot showing chloride concentration during time series sampling................. 42

Figure 40: Plot showing nitrate concentration during time series sampling.................... 43

Figure 41: Plot showing sulfate concentration during time series sampling ................... 43

Figure 42: Plot showing sodium concentration during time series sampling .................. 44

Figure 43: Plot showing potassium concentration during time series sampling............... 44

Figure 44: Plot showing calcium concentration during time series sampling .................. 45

Figure 45: Plot showing magnesium concentration during time series sampling ............ 45

Figure 46: Plot showing strontium concentration during time series sampling............... 46

Figure 47: Plot showing silica concentration during time series sampling .................... 46

Figure 48: Plot showing magnesium/calcium ratio during time series sampling ............ 47

Figure 49: Plot showing $\delta^{13}$ CDIC values during time series sampling............................. 47

Figure 50: Plot showing $\delta^{2} \mathrm{H}$ and $\delta^{18} \mathrm{O}$ values during time series sampling .................... 48

Figure 51: Map showing summer background bug results before dye injections ............ 50

Figure 52: Map showing summer baseflow trace bug results...................................... 50

Figure 53: Plot showing water level and EC at Laoheitan.......................................... 51

Figure 54: Map showing summer stormflow trace bug results..................................... 52

Figure 55: Field photograph of Xiao Shanba on December 3 ..................................... 56

Figure 56: Field photographs of Liugu showing the progression of dye arrival .............. 56

Figure 57: Map showing results of winter bugs retrieved $1 \mathrm{~d}$ after injections ................. 57

Figure 58: Map showing results of winter bugs retrieved 2 and $3 \mathrm{~d}$ after injections........ 57

Figure 59: Map showing results of winter bugs retrieved 4, 5, and $6 \mathrm{~d}$ after injections... 57

Figure 60: Map showing results of winter bugs retrieved $8 \mathrm{~d}$ after injections ................. 58

Figure 61: Maps comparing synoptic water sample saturation index wrt calcite............. 64

Figure 62: Maps comparing synoptic water sample saturation index wrt dolomite ......... 64

Figure 63: Maps comparing synoptic water sample saturation index wrt strontianite ..... 65

Figure 64: Maps comparing synoptic water sample saturation index wrt gypsum........... 65

Figure 65: Maps comparing synoptic water sample saturation index wrt celestite .......... 66

Figure 66: Plot showing saturation index wrt calcite during time series sampling .......... 67

Figure 67: Plot showing saturation index wrt dolomite during time series sampling ...... 67

Figure 68: Plot showing saturation index wrt strontianite during time series sampling... 68

Figure 69: Plot showing saturation index wrt gypsum during time series sampling ........ 68

Figure 70: Plot showing saturation index wrt celestite during time series sampling........ 69

Figure 71: Conceptual map showing summer baseflow ............................................. 74

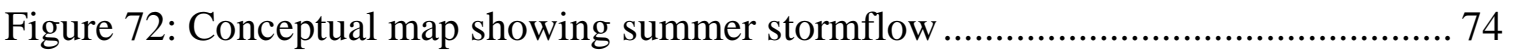

Figure 73: Conceptual map showing winter baseflow............................................. 74 


\section{CHAPTER 1. INTRODUCTION}

Understanding how karst aquifers store and transmit water, as well as contaminants, is an ongoing problem in hydrogeology. Water movement through karst systems is complex and not well understood, predominantly because of flowpath and recharge heterogeneity. Research to better understand karst systems is imperative not only because $25 \%$ of the world's population get their drinking water from karstic aquifers, but also because these systems are uniquely prone to water-supply mismanagement and contamination (Ford and Williams, 2007). This study explores groundwater flow by monitoring water parameters at multiple locations with varying temporal and spatial frequencies within the karstic Houzhai catchment. This 73.5 km² basin in Guizhou province, China, is located in the center of the largest karst area in the world, the Southeast Asian karst region (Wang and Zhang, 2001; Li et al., 2010) (Figures 1 and 2). Exposed carbonate rocks account for just over 20\% of the land surface in China, making this location a key area of karst research (Cao et al., 2015). The study advances our understanding of how this system functions and may react to changes in environmental conditions such as land use/land cover and rainfall. The study also compares karst system functioning between the summer monsoon season and the winter dry season. 


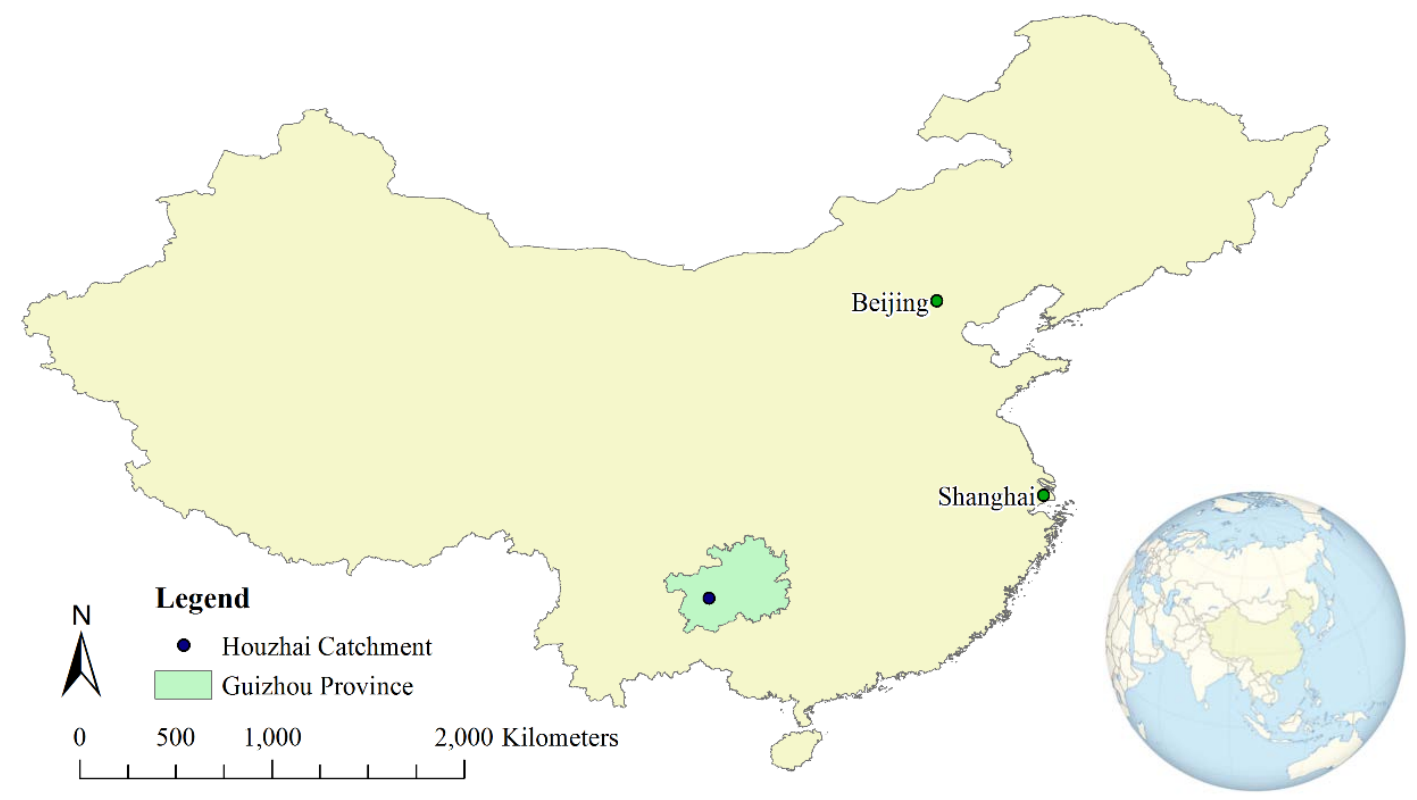

Figure 1: Context map of China with Guizhou province in green and the Houzhai catchment indicated by the circle. World map from Wikimedia Commons.

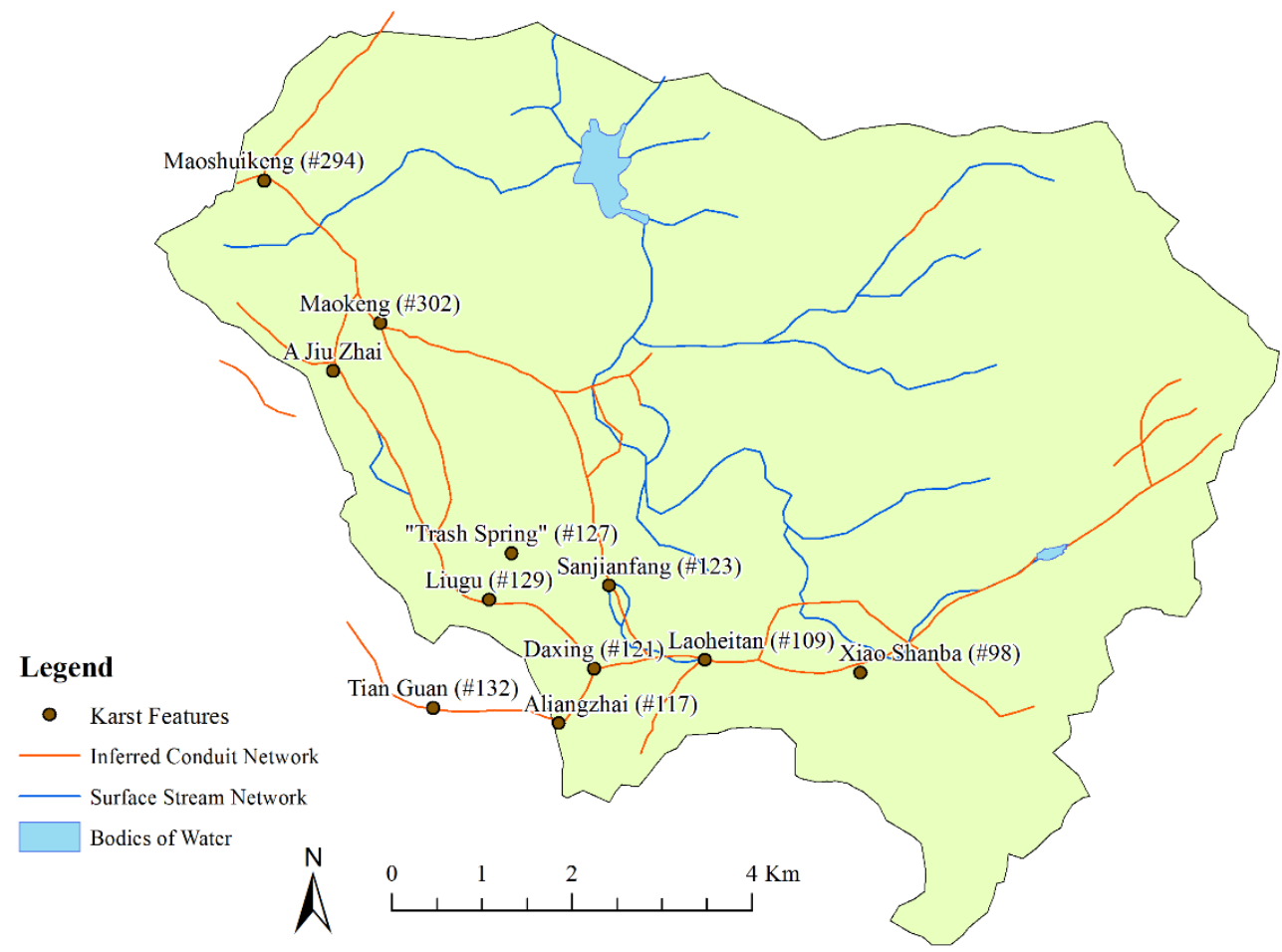

Figure 2: Houzhai catchment map with monitored karst features (labeled and numbered), inferred karst conduit network, surface stream network, and bodies of water. 
Approximately 32,400 people lived within the Houzhai catchment as of 2010 and, at this time, agriculture was the main livelihood for upwards of 95\% of them. (Li et al., 2010). Runoff from organic fertilizers has the potential to travel rapidly through the subsurface, arriving at springs without the time needed to filter out contaminants, such as excess nutrients and fecal bacteria, thereby posing a significant risk to drinking water quality (Li et al., 2010). Another major threat to the agricultural way of life that dominates this area is a thinning of the soil layer, known as rocky desertification, which is often exacerbated by a combination of climate change and deforestation (Liu et al., 2010). Soil loss not only reduces vegetation coverage and makes farming less productive, but it also decreases epikarst groundwater storage, thus making the springs that the local population depend on for water supply less reliable (Liu et al., 2010). Identifying flowpaths in karst systems is important because flowpath type and length are the main controls on groundwater residence time, which has major significance for groundwater quality. Generally, longer groundwater residence time decreases the risk of dangerous pathogen contamination (Scanlon, 1990). Additionally, identifying sources of recharge is necessary for gauging contamination risk. For example, if agricultural runoff is a significant source of recharge for a karst spring that discharges high-velocity conduit flow, the quality of the spring water is likely questionable.

This study extends our understanding of the Houzhai catchment by measuring artificial tracers to identify specific flowpaths and calculate water flow velocities during both monsoon and dry seasons. It also identifies water chemistry variations, both spatial and temporal, from which inferences about system function can be made. 


\subsection{Previous Research}

The study of karst systems has an extensive history due to their widespread significance as water sources. One in four people are completely or partially dependent on drinking water from karst aquifers (Ford and Williams, 2007). Additionally, karst landscape development, such as the formation of sinkholes, poses risks to human infrastructure as $10 \%$ of the continental land mass is characterized as karstic (Ford and Williams, 2007).

In their widely cited paper, Shuster and White (1971) categorized karst springs on a spectrum between diffuse and conduit flow based on long-term variability of spring water chemistry. Since then, significant effort has been dedicated towards identifying patterns in karst spring hydrographs and chemographs to interpret spring flow behavior. For example, Liu et al. (2004) identified fracture and conduit flow using $\mathrm{CO}_{2}$ and calcite saturation-index calculations during flooding periods. They found that $\mathrm{CO}_{2}$ concentration in conduit water during flood periods is lower than during baseflow while $\mathrm{CO}_{2}$ concentration in fracture water is higher during flood periods than baseflow (Liu et al., 2004). The opposite relationship is true with calcite saturation-index (Liu et al., 2004). Lakey and Krothe (1996) identified storm recharge in karst systems through isotopic analyses, allowing for hydrograph separation. They found that phreatic water already in the karst system had significantly depleted $\delta^{18} \mathrm{O}$ and $\delta^{2} \mathrm{H}$ values in comparison to the rain water and were able to use the change in water isotopic composition and discharge at the spring to separate rain water from pre-storm water (Lakey and Krothe, 1996). $\mathrm{Mg}^{2+} / \mathrm{Ca}^{2+}$ ratios can be used as an indicator of relative residence time of subsurface water (Ford and Williams, 2007; Langmuir, 1971; Musgrove and Banner, 2004). Musgrove and Banner 
(2004) found that higher $\mathrm{Mg} / \mathrm{Ca}$ and $\mathrm{Sr} / \mathrm{Ca}$ values can indicate diffuse recharge because longer residence times allow for preferential precipitation of calcite, which tends to exclude $\mathrm{Mg}^{2+}$ and $\mathrm{Sr}^{2+}$, therefore leaving those ions in solution.

At the study site, previous work has looked at dissolution rates and exchange between fast- and slow-flow systems during wet and dry periods (Zhang et al., 2017). Hourly hydrometric and isotope data were used to estimate storage and water age from fast flow, hillslope, and slow flow reservoirs within the Chenqi sub-catchment within the Houzhai basin (Figure 6) (Zhang et al., 2019). Yan et al. (2012) conducted a long-term (21-year) surface-water chemistry study of the Houzhai outlet and found that fluxes of dissolved $\mathrm{Ca}^{2+}, \mathrm{Mg}^{2+}, \mathrm{HCO}_{3}{ }^{-}$, and $\mathrm{SO}_{4}{ }^{2-}$ slowly increased while $\mathrm{Na}^{+}, \mathrm{K}^{+}$, and $\mathrm{Cl}^{-}$fluxes slowly decreased as a result of increased karst weathering. They also found that rainfall had the most important influence on dissolved inorganic carbon (DIC) flux, which averaged 24.2 grams of carbon per square meter per year $\left(10.1 \mathrm{~g} \mathrm{C} \mathrm{m}^{-2} \mathrm{yr}^{-1}\right.$ to $34.1 \mathrm{~g} \mathrm{C} \mathrm{m}^{-}$ $\left.{ }^{2} \mathrm{yr}^{-1}\right)$, a value that is important in constructing carbon budgets (Yan et al., 2012). Yang et al. (2012) found that soil $\mathrm{CO}_{2}$ and rainfall play a major role in epikarst spring electrical conductivity (EC), $\mathrm{P}_{\mathrm{CO} 2}$, and $\mathrm{pH}$ variability. Using carbon stable isotope compositions, $\mathrm{Li}$ et al. (2010) showed that the production of $\mathrm{CO}_{2}$ from organic matter oxidation significantly impacts carbonate dissolution within the catchment.

Zhang et al. (2016) found that karst aquifer storage capacity increases along catchment flowpaths, with more conduits and well-connected fissures upstream and more matrix and poorly-connected fissures downstream. Chen et al. (2018) focused on Chenqi when conducting electrical resistivity tomography (ERT) geophysical surveys to quantify spatial heterogeneity of epikarst and aquifer permeability. Combining these geophysical 
results with water temperature and $\delta^{18} \mathrm{O}$ and $\delta^{2} \mathrm{H}$ data helped them probe the structure of the karst critical zone. Chen et al. (2013) found that, during flooding periods, surface streams only drain around $8 \%$ of total water discharge from the catchment, meaning that the bulk of flow is occurring as groundwater discharge. Yue et al. (2018) found that water isotope values deviate from the GMWL during the winter. They interpret those observations as resulting from evaporative loss during the dry season (Yue et al., 2018). Wang and Zhang (2001) document the results of four "pulse tests", which are analogous to large-scale slug tests, within the Houzhai catchment between 1988 and 1991. They found that water flow velocity ranged from $200-800 \mathrm{~m} / \mathrm{hr}$, with higher flow velocities during the wet season and lower flow velocities during the dry season (Wang and Zhang, 2001). These pulse tests have also been used to identify three different "types of aquifer media” based on their response and flow recession curve (Yang, 2001).

This study will build upon previous work, identifying specific flow paths in order to develop a better understanding of how this karst system functions. Ideally, these results will lead to better source-water protection practices. This site was chosen because the conduit network is reasonably well delineated, but information on responses of springs to storms is limited, and there are no known results of dye tracing within the catchment. 


\subsection{Site Location}

The Houzhai catchment is classified as a typical mountain karst river basin (Wang and Zhang, 2001) (Figure 2). Elevation ranges from $1552 \mathrm{~m}$ above sea level (masl) to 1212 masl at the outlet, with a decreasing slope from southeast to northwest. Numerous karst peaks add to the relief, especially in the eastern part of the catchment (Figure 3). The Houzhai catchment is located from $26^{\circ} 11^{\prime} 39^{\prime \prime}$ to $26^{\circ} 17^{\prime} 14^{\prime \prime}$ 'North latitude and from $105^{\circ} 40^{\prime} 41^{\prime \prime}$ to $105^{\circ} 48^{\prime} 11^{\prime \prime}$ East longitude.

\subsubsection{Climate}

The Houzhai catchment has a subtropical humid monsoon climate typical of southern China (Zhang et al., 2016). This means that around $80 \%$ of the average annual precipitation ( 1300 mm) falls during the monsoon season, which lasts from May to October (Li et al., 2010). Annual precipitation can vary significantly from year to year. For example, from 1991 to 2001 the annual precipitation ranged from 847 to $1794 \mathrm{~mm}$ (Zhang et al., 2016). Total annual precipitation in 2018 amounted to $1290 \mathrm{~mm}$, right in the middle of the historical range. Mean annual evaporation is around $920 \mathrm{~mm}$ (Wang and Zhang, 2001). Historical annual air temperature is $20.1^{\circ} \mathrm{C}$ (typically ranging from $16^{\circ} \mathrm{C}$ to $22^{\circ} \mathrm{C}$ ), with highest temperatures in July and lowest temperatures in January (Chen et al., 2013; Zhang et al., 2017). Average air temperature for 2018 was $18.3^{\circ} \mathrm{C}$. Climate change has impacted southwest China by increasing flood and drought frequency (Lian et al., 2015), which is likely to have adverse effects on agricultural productivity. 


\subsubsection{Land Use}

Agriculture plays a major role in the land use of the Houzhai catchment. Water resources are used mainly for drinking and irrigation (Li et al., 2010). In the wet season, corn and rice are the main crops grown in this area. "Cultivated area” accounts for 20\% of the total catchment area, two-thirds of which consists of rice paddies (Hu et al., 2001). Both corn and rice are water-intensive to produce and pumping was observed at many of the springs in this study to fill rice paddies and for domestic uses. In the dry season, canola and various vegetables are grown (Yue et al., 2018). Diammonium phosphate, urea, and organic fertilizers are commonly applied to fields from April through July (Yue et al., 2018). Recent surveys by Buckerfield et al. (2019) show that the rural population living within the catchment is relatively unaware of the dangers associated with the usage of organic fertilizers. Even though 44\% of farmers surveyed within the catchment used human or animal waste as fertilizer, $60 \%$ did not know that this waste can carry pathogens (Buckerfield et al., 2019). Additionally, 58\% of surveyed farmers “did not think that their farming activities held any consequence for downstream users of water” and 60\% said "they did not know how water moves through the environment" (Buckerfield et al., 2019). Overall, this highlights a lack of communication between scientists and the local population. Furthermore, governmental policy to slow the growth rate of chemical fertilizer usage to zero by 2020 is potentially poised to increase water contamination risk (Agriculture, 2015). According to Chadwick et al. (2015), this policy measure is likely to result in an increase in the use of organic fertilizers (human and animal waste) to compensate for chemical fertilizers becoming less available. 


\subsubsection{Geology}

Karst features within the Houzhai catchment are developed in the Triassic Guanling Formation. Lithology consists mainly of limestone and dolomite, with beds dipping between 5-25 northwest (Liu et al., 2010). Yang (2001) standardized the three members of this formation, denoting them $\mathrm{T}_{2} \mathrm{~g}^{1}, \mathrm{~T}_{2} \mathrm{~g}^{2}$, and $\mathrm{T}_{2} \mathrm{~g}^{3}$ (Figure 4). The oldest of these members, $\mathrm{T}_{2} \mathrm{~g}^{1}$, is $~ 200 \mathrm{~m}$ thick and composed of shales, thin argillaceous dolomite, and interbedded argillaceous limestone (Liu et al., 2010). It outcrops mainly in the upstream part of the catchment. $\mathrm{T}_{2} \mathrm{~g}^{2}$ is $\sim 240 \mathrm{~m}$ thick and composed of grey thin limestone and medium thick limestone, marlite, dolomitic limestone, and thin argillaceous limestone (Liu et al., 2010). The youngest member, $\mathrm{T}_{2} \mathrm{~g}^{3}$, is composed of medium-thickness dolomite beds that thicken up-section. Only a 100-m-thick interval of this member outcrops within the catchment.

Due to the nature of karstic terrane, hydrological boundaries are often not able to be well delineated and frequently overlap (White, 1988). Within the Houzhai catchment, shale and marlite units act as topographic boundaries to the north and southwest and provide a base for the karst aquifer (Chen et al., 2013). The Yuguan fault acts as a noflow boundary to the east and southeast (Chen et al., 2013). The Mugong River lies to the southwest and Chen et al. (2013) state that there is little exchange between the river and the karst conduit system.

Geomorphically, the Houzhai catchment is characterized by cockpit karst, which is comprised of conical hills and star-shaped valleys that formed during the Neogene under tropical climatic conditions (Chen et al., 2018; Yu and Zhang, 1988). The 
catchment topography has been divided into three main regions: peak-cluster depressions, peak-cluster valley and trough valley combination, and peak-cluster basin and hill combination (Figure 5) (Liu et al., 2010). Peak-cluster depressions dominate the eastern, higher-elevation part of the catchment (Figure 5). These closed depressions exhibit sinkholes that transfer runoff quickly underground. The second geomorphic region is located in the center of the catchment and represents a transition zone between peakcluster depressions and peak-cluster basin. Flow in this region is mainly lateral. Lastly, the geomorphic region of peak-cluster basin and hills is located near the outlet of the catchment.

Carbonate rocks are usually exposed on the surface (Li et al., 2010). Soils are generally thin (average $<50 \mathrm{~cm}$ ) and discontinuous on the eastern half of the catchment and thicker on the western half (Li et al., 2010). Generally, these clayey soils have relatively low water retention capacity (Yue et al., 2018). High clay content helps prevent water leakage from rice paddies. 


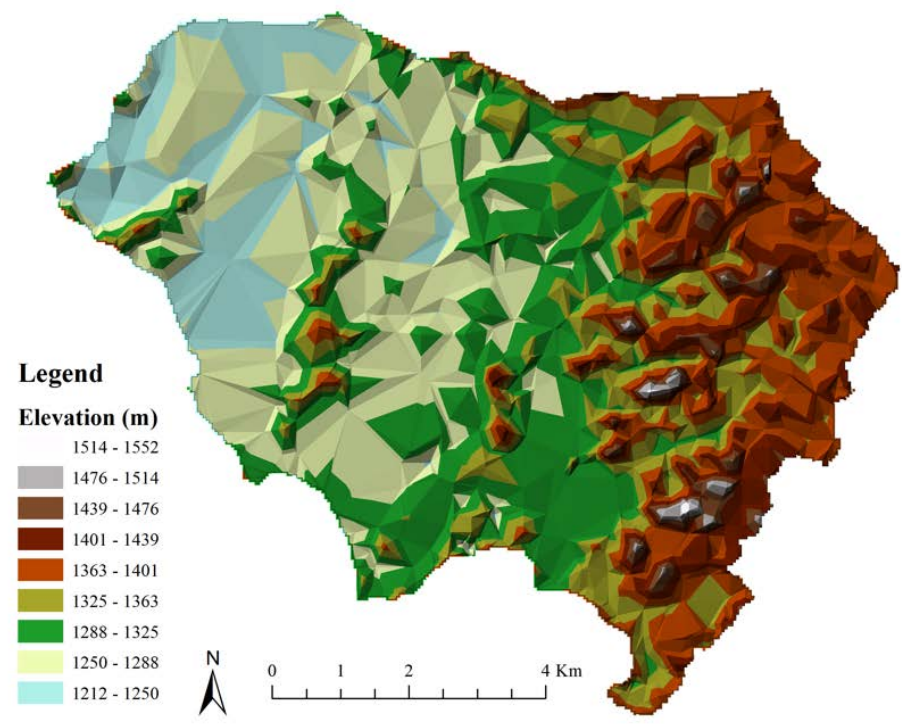

Figure 3: Triangular irregular network (TIN) map showing surface elevation of the Houzhai catchment.

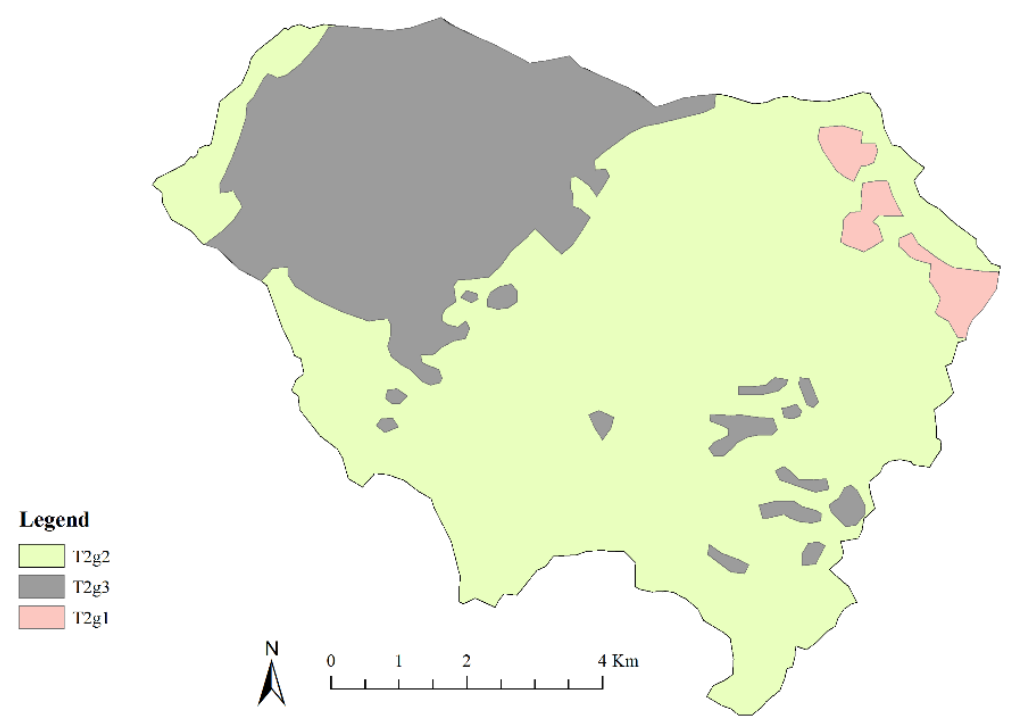

Figure 4: Geologic map of the Houzhai catchment showing the distribution of the surficial outcrops of the three members of the Guanling Formation. Data from Liu et al. (2010). 


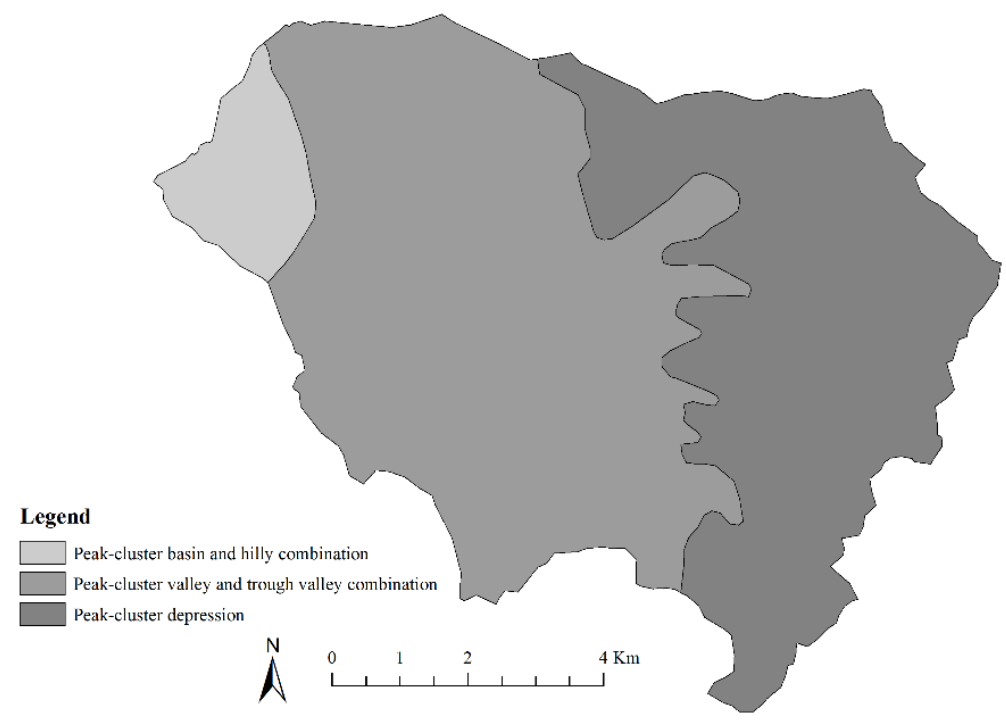

Figure 5: Geomorphic classification map of the Houzhai catchment. Data from Liu et al. (2010).

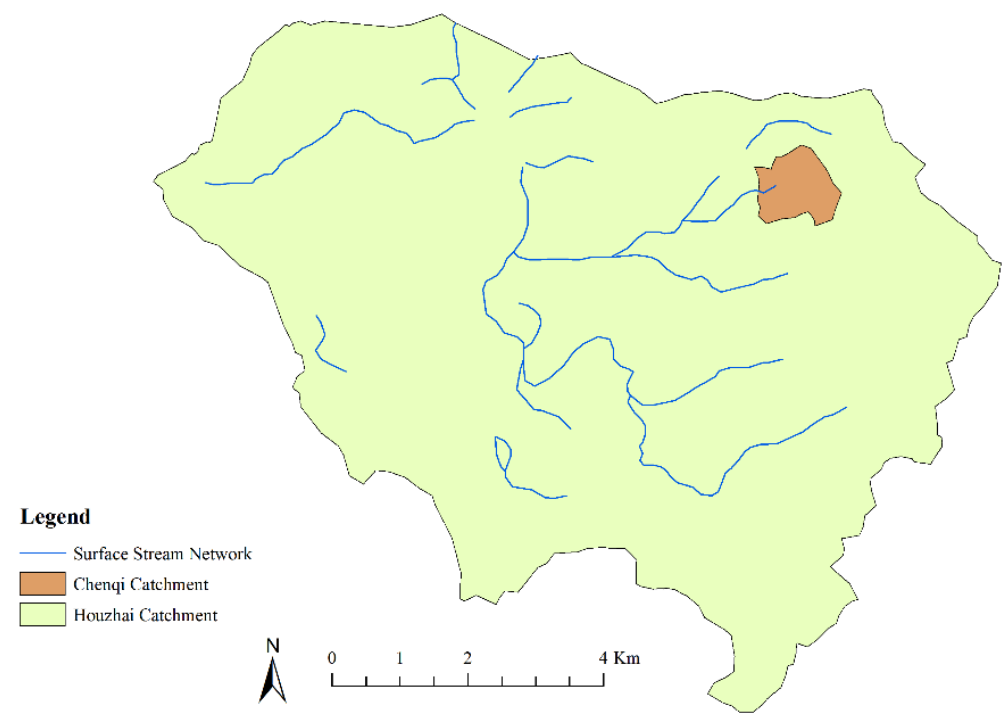

Figure 6: Location of the Chenqi subcatchment within the Houzhai catchment. 


\subsubsection{Hydrogeology}

Water leaves the Houzhai catchment at Maoshuikeng, located in the northwest corner of the catchment (Figure 2). Average annual discharges from underground and surface streams are roughly equivalent, with $23.3 \times 10^{6} \mathrm{~m}^{3} / \mathrm{yr}$ discharging from the underground conduits and $24.9 \times 10^{6} \mathrm{~m}^{3} / \mathrm{yr}$ discharging from the surface streams (Li et al., 2010). Mean annual water temperature is $16.7^{\circ} \mathrm{C}$ (Yan et al., 2012). Surface water $\mathrm{pH}$ averages 7.5, fluctuating between 7.2 in the summer and 7.9 in the winter (Yan et al., 2012). In general, water levels at the karst feature locations in this study were significantly higher during the summer monsoon season than during the winter dry season (Figures 7, 8, 9, and 10).
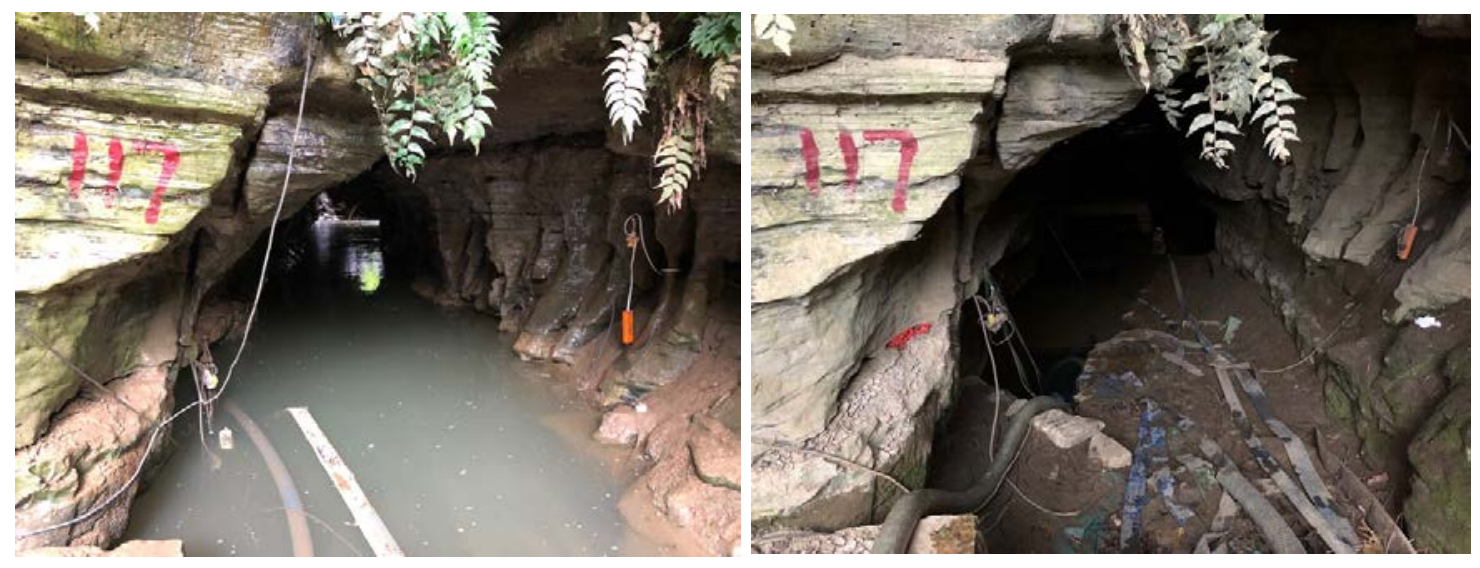

Figure 7: Comparison of two field photographs of the karst feature at Aliangzhai (location \#117, Figure 2) during the summer monsoon season (left) and winter dry season (right). 

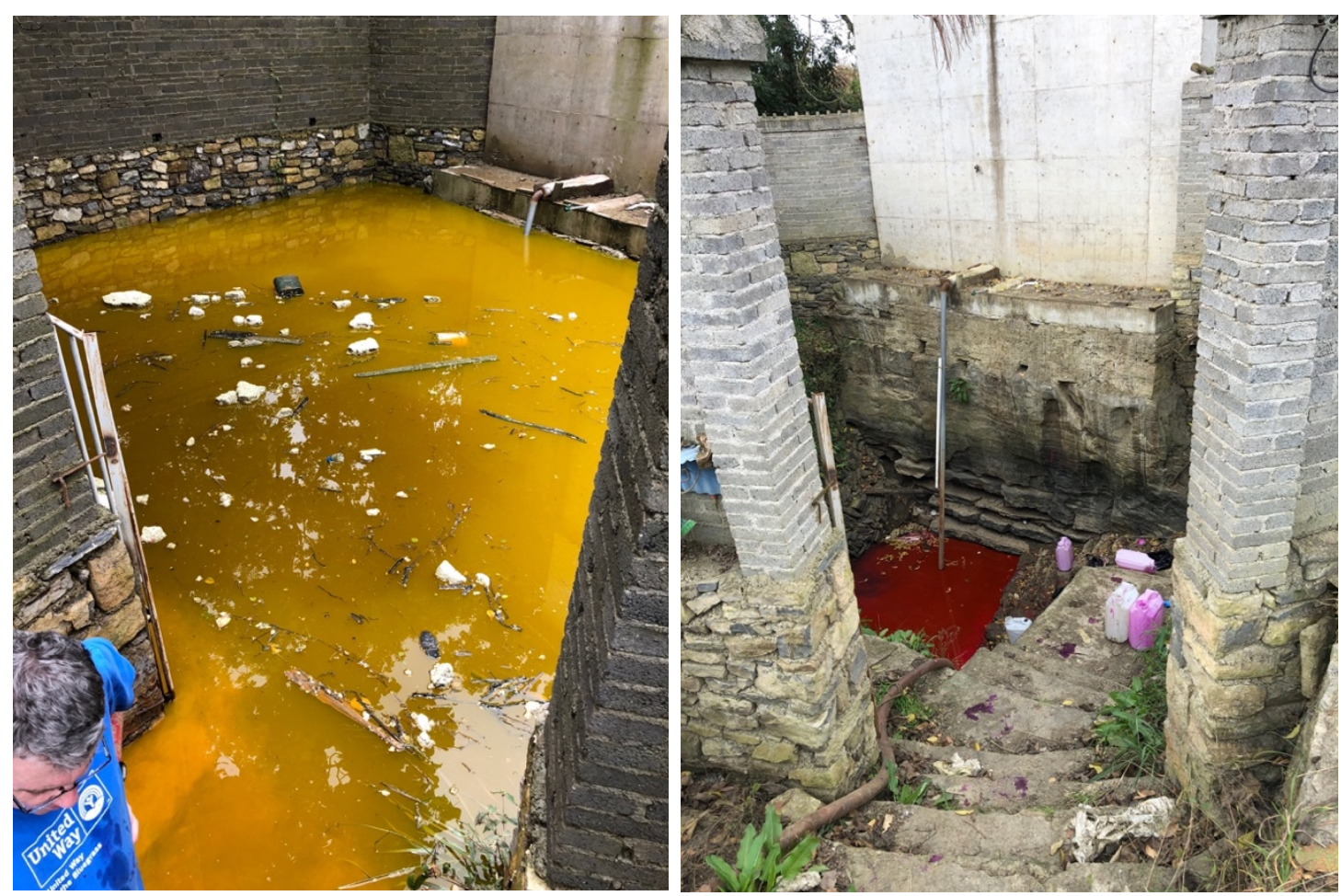

Figure 8: Comparison of two field photographs of Daxing (location \#121, Figure 2) during the summer monsoon season (left) and winter dry season (right). Each image was captured after a dye injection.
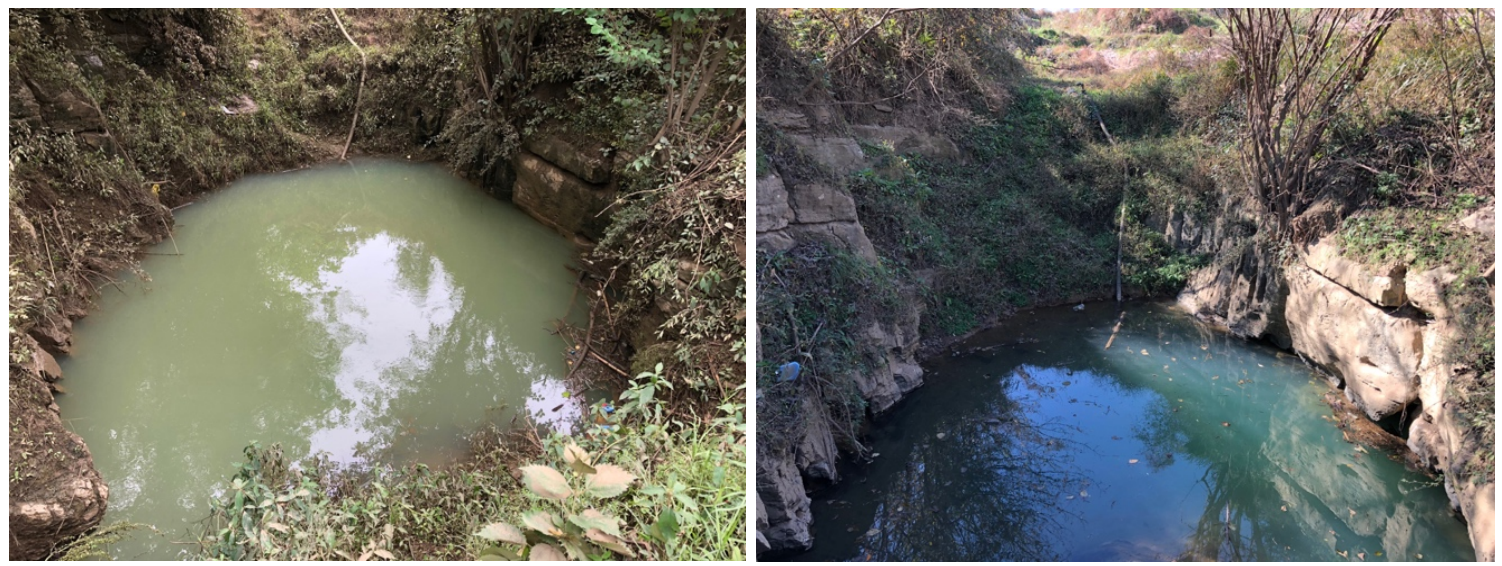

Figure 9: Comparison of two field photographs of Liugu (location \#129, Figure 2) during the summer monsoon season (left) and winter dry season (right). 

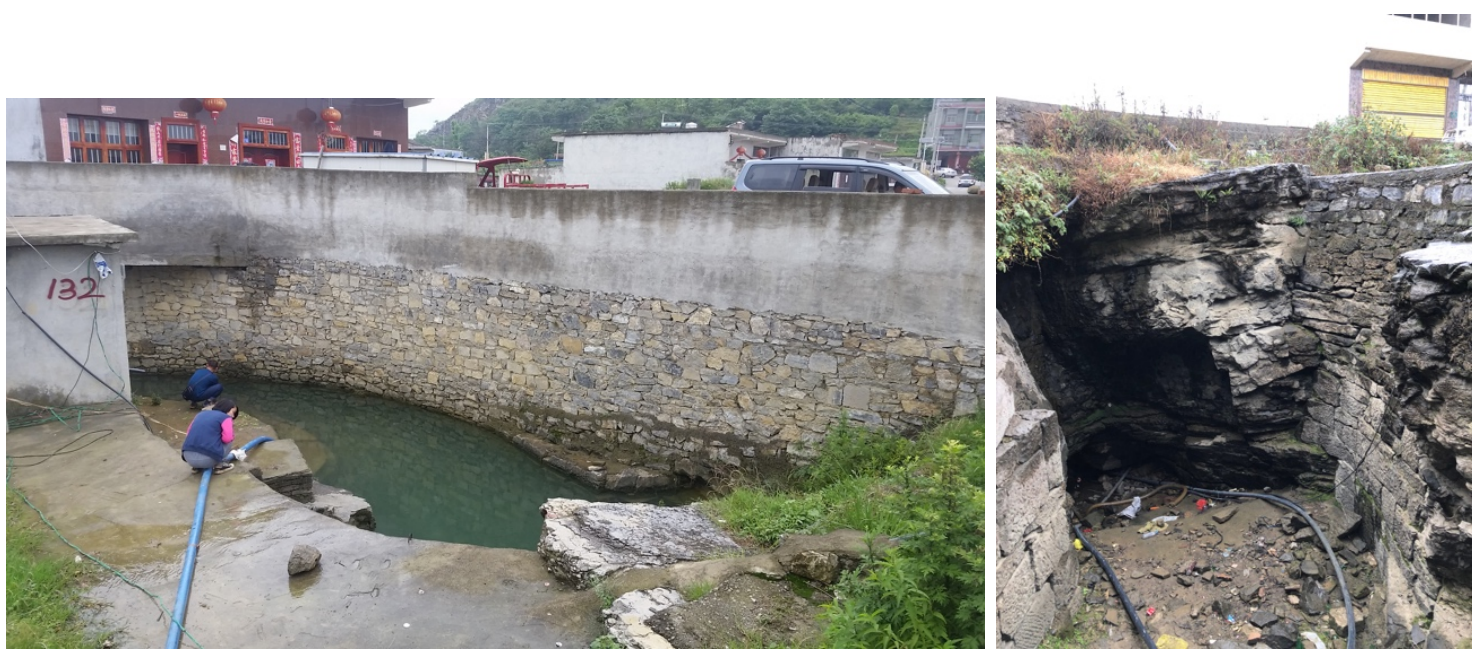

Figure 10: Comparison of two field photographs of Tian Guan (location \#132, Figure 2) during the summer monsoon season 2017 (left) and winter dry season 2018 (right). The rock ledge in the image on the right matches up with the location of where the man in blue is squatting in the image on the left. 


\section{CHAPTER 2. METHODS}

\subsection{Overview}

Fieldwork was conducted for 2 weeks during the summer monsoon season (June 2018) and 2 weeks during the winter dry season (December 2018). During the summer, synoptic baseflow monitoring of field parameters, major solutes, and stable isotopes occurred at 11 springs and karst windows in the southern portion of the Houzhai catchment. Additionally, EC, temperature (T), and stage were logged at 5-min intervals at three springs over periods of 4-7 d. A simultaneous injection of dye and salt $(\mathrm{NaCl})$ occurred during baseflow conditions at a karst window. Water chemistry was monitored after a stormflow dye injection at 1- to 2-h intervals for $46 \mathrm{~h}$ on the falling limb of the hydrograph at Maoshuikeng (the outlet spring; location \#294). During the dry season, baseflow monitoring of field parameters, major solutes, and stable isotopes occurred at nine of the previous 11 locations because the other two were dry. Additionally, two baseflow dye injections at two separate karst features occurred on the same day and the other karst features were monitored for the presence of dye for $8 \mathrm{~d}$ after the injections.

\subsection{Synoptic Sampling and Continuous Logging}

Synoptic sampling during the summer field season occurred on June 16 at 11 locations throughout the southern portion of the Houzhai catchment (Figure 2). During the winter field season, synoptic sampling occurred on December 3 at the same locations except Trash Spring (location \#127) and A Jiu Zhai (a karst valley) because they were dry. In addition to collecting samples for analyses of anions, metals, and stable isotopes, water parameters including specific conductance (SC), water temperature (T), EC, pH, 
and carbonate alkalinity were also measured in the field. The first three parameters were measured using a YSI 556 meter while pH was measured using an Orion 290A meter. During the summer, an Orion 130 probe was used to independently duplicate EC measurements. Alkalinity was measured in the field as $\mathrm{mg} / \mathrm{L} \mathrm{CaCO}_{3}$ using a handheld colorimeter (a Hanna Freshwater Alkalinity Checker). Water samples were passed through disposable 0.45 -micron syringe filters and samples for metals analysis were acidified using $1 \%$ nitric acid to prevent precipitation of solids. The samples were refrigerated until testing.

Continuous loggers were deployed during the summer at Laoheitan (location \#109) (June 15-21), 370 m downstream of Maoshuikeng (location \#294) (June 21-25), and Daxing (location \#121) (June 15-25). These included both Solinst Leveloggers and Hobo conductivity loggers, which together measured T, water level, and EC at 5-min intervals. Measured water levels were corrected for barometric pressure fluctuations using a Solinst Barologger deployed at Laoheitan. The loggers were placed at the bottom of a PVC stilling well with other sensors that were deployed at each location. A weight was used at Laoheitan to ensure they stayed on the bottom of the bed. At Daxing, the stilling well was attached to a pipe in an effort to keep the loggers in place (see Figure 8), but the water level fluctuated greatly and sometimes exposed the loggers to the air. A weather station located at Laoheitan (location \#109) and maintained by Puding research station staff measured precipitation at 5-min intervals throughout both the summer and winter field seasons. 


\subsection{Dye Tracing}

\subsubsection{Passive Dye Sampling}

Passive samplers ("bugs”) were constructed using wire mesh that was folded and stapled to contain $\sim 2$ tablespoons ( $30 \mathrm{~mL}$ ) of granular activated charcoal (Figure 11A). Each bug was tied to a steel pipe elbow in order to ensure submersion; this elbow was then tied to a rope to allow for easy retrieval (Figure 11B). Additionally, a strip of cotton cloth was tied around the elbow and deployed with the background bugs in order to check for the presence of optical brighteners (from detergent in wastewater).

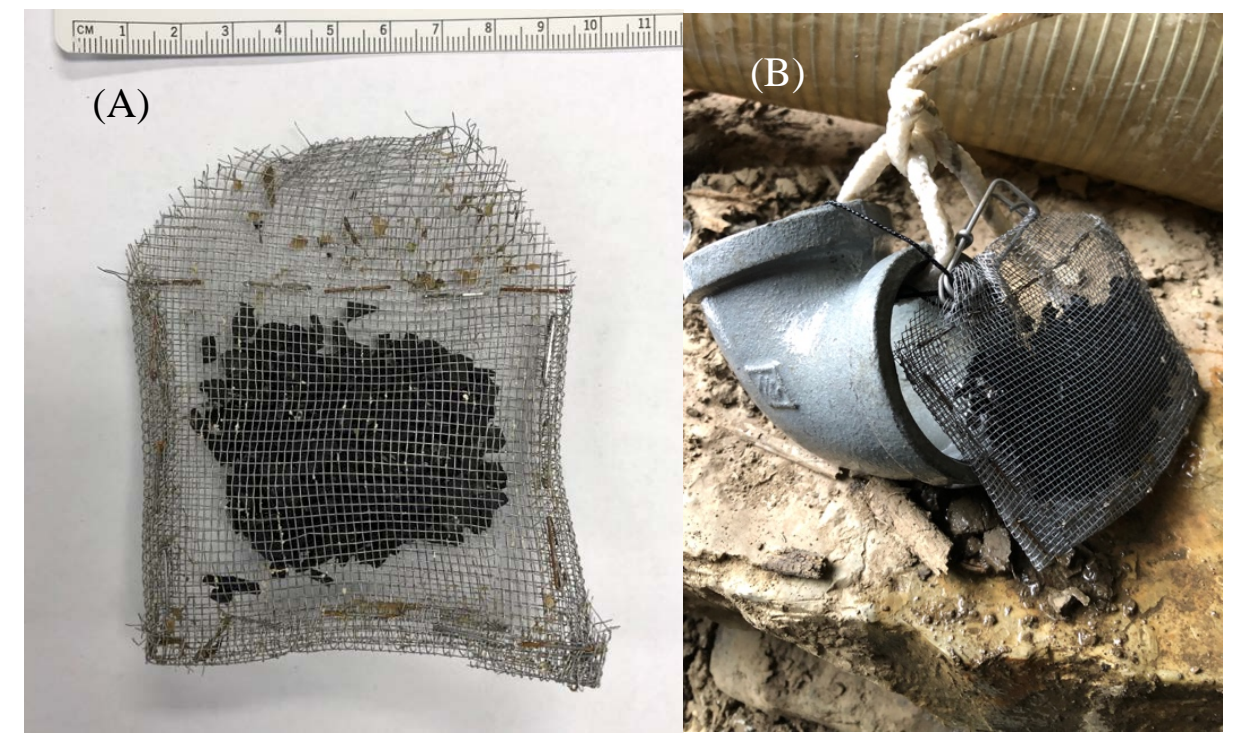

Figure 11: Images of charcoal bugs used to record the presence of dye.

During the summer, background bugs were deployed on June 14 at 11 karst features and swapped out on June 16 during synoptic sampling at those locations (Figure 2). New bugs were deployed from the $16^{\text {th }}$ to the $21^{\text {st }}$ in order to capture dye from the baseflow dye injection, which occurred on the $17^{\text {th }}$. On the $21^{\text {st }}$, three more bugs were deployed at Aliangzhai, Liugu, and Maoshuikeng (locations \#117, \#129, and \#294, 
respectively) in an attempt to capture dye from the stormflow dye trace, which occurred on the $23^{\text {rd }}$. These bugs and one at A Jiu Zhai were collected on the $25^{\text {th }}$.

During the winter, background bugs were deployed on December 3 at seven locations (five potentially downgradient karst features and the two dye injection locations). The five downgradient bugs were swapped out at the time of the injections and each day thereafter in an effort to capture the first arrival of dye as it moved through the conduit network. In order to hedge against the possibility that a single day would not be long enough for bugs downgradient of the injection points to adequately absorb a measurable amount of dye, a second set of bugs was deployed and swapped at a 2-d interval. This process of bug swapping occurred until the $11^{\text {th }}, 6 \mathrm{~d}$ after the dye injections. Bugs were then left at the two locations furthest from the injection sites for another $2 \mathrm{~d}$ in order to maximize the time of data collection and attempt to capture the first arrival of dye at these locations.

Each bug was kept in its own separate zip-lock bag. During the summer, the background and baseflow/stormflow bugs were stored separately in their own large ziplock bags, while in the winter, the bugs from each day were stored separately. Care was taken in transport to keep the dye and bugs as separated as possible. When the dye was dissolved in water and transported to the field for injection during the summer, a separate truck was used in order to minimize the chances of cross-contamination with the primary field vehicle. As a check for cross-contamination, field-blank bugs were constructed and transported everywhere that the other bugs went. Once the bugs were collected from the field, they were transported back to the laboratory, rinsed with deionized water, and dried overnight in an oven set to $80^{\circ} \mathrm{C}$. The cotton cloth was also dried and then visually 
inspected under a handheld ultraviolet light in a dark room. An attempt was made to identify the presence or absence of fluorescent dye from the background bugs at Guizhou Minzu University on June 20. However, due to numerous challenges, this was not achieved. Therefore, the remaining charcoal from those bugs, the summer baseflow/stormflow bugs, and all of the bugs deployed during the winter field season were brought back to the United States and analyzed using a scanning spectrofluorometer at the Kentucky Geological Survey (KGS) lab on the University of Kentucky campus.

\subsubsection{Summer Baseflow Trace}

At 1:30 pm on June 17, $5.5 \mathrm{~kg}$ of fluorescein dye dissolved in $\sim 300 \mathrm{~L}$ of water, with $80 \mathrm{~L}$ of water to flush the dye, was injected at Xiao Shanba (location \#98) (Figure 12). Simultaneously, $\sim 900 \mathrm{~kg}$ of $\mathrm{NaCl}$ dissolved in $\sim 4000 \mathrm{~L}$ of water pumped from Xiao Shanba the previous day was also injected. A metric ton of salt was intended to be used, but due to logistical difficulties with dissolving the salt in three separate tanks, 10\% of the salt (by visual estimation) was left undissolved in the bottom of the tanks. It had not rained since June 12 (total $19.2 \mathrm{~mm}$ ) and there was no rain on the $17^{\text {th }}$, so this was considered a baseflow dye injection. In addition to the charcoal bugs, conductivity loggers were deployed at Laoheitan (location \#109) and Daxing (location \#121) in order to measure the conductivity pulse from the salt injection. Unfortunately, due to waterlevel drop, the conductivity sensor at Daxing was not submerged during the injection. The sensor at Laoheitan functioned properly. 

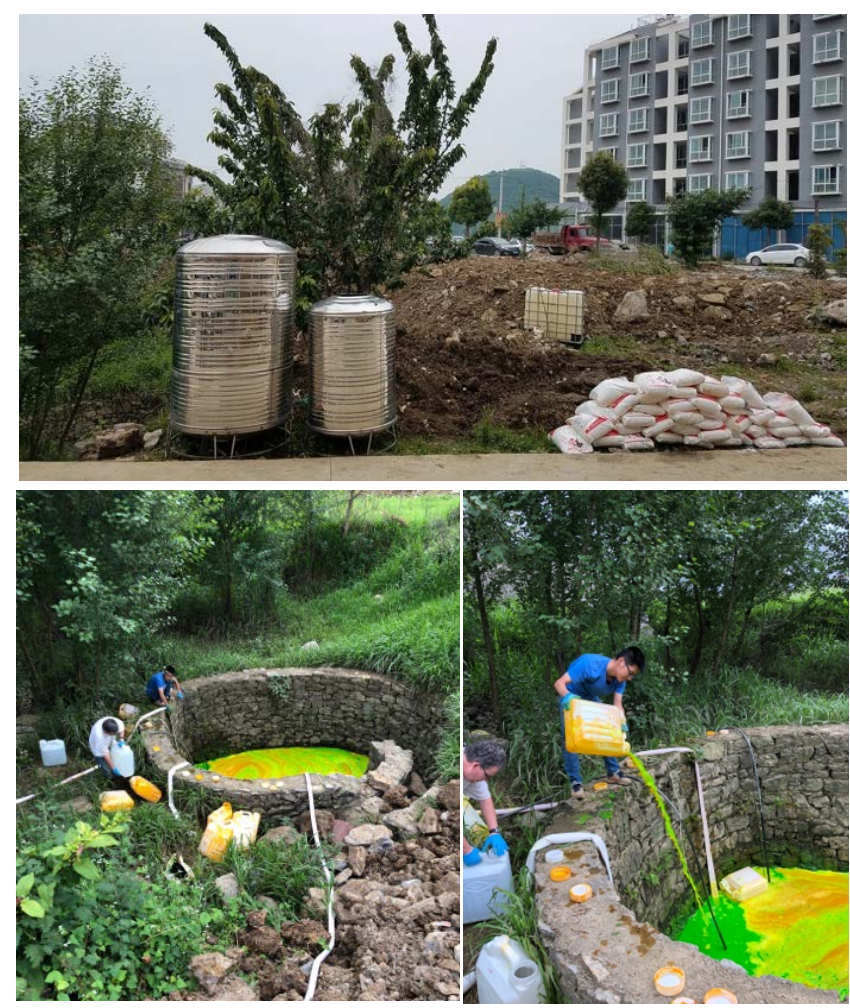

Figure 12: Field photographs showing summer salt injection and baseflow dye injection at Xiao Shanba.

\subsubsection{Summer Stormflow Trace}

At 1:00 pm on June $23, \sim 3.2 \mathrm{~kg}$ of eosine dye dissolved in $\sim 175 \mathrm{~L}$ of water and flushed with another 80 L of water was injected at Daxing (location \#121) (Figure 13). Because high turbidity limited filter effectiveness, only three water samples were taken at this location: one directly after the dye injection, the second $24 \mathrm{~h}$ after injection, and the third $48 \mathrm{~h}$ after injection. It did not rain directly before or during the injection, but $60 \mathrm{~mm}$ of precipitation was recorded at Laoheitan in the $48 \mathrm{~h}$ prior to injection. Unlike the baseflow dye trace at Xiao Shanba, dye was no longer visible only 50 min after injection. 


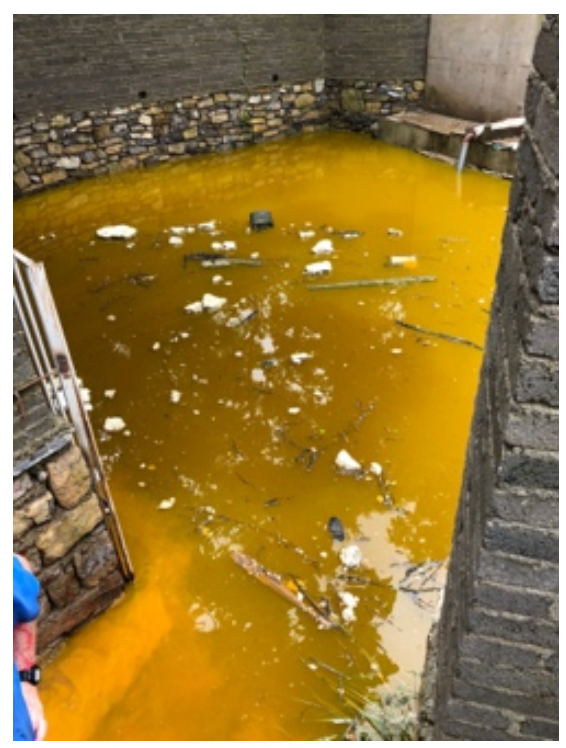

Figure 13: Field photograph showing summer stormflow dye injection at Daxing.

The majority of the sampling took place at Maoshuikeng (location \#294). Sampling began at 3:05 pm, resumed at 5:00 pm, and continued every $2 \mathrm{~h}$ on the hour for $24 \mathrm{~h}$, then switched to hourly intervals for another $24 \mathrm{~h}$. In addition to collecting and filtering water samples for dye, alkalinity, anion, metal(loid), and stable isotope analyses, water parameters including $\mathrm{T}, \mathrm{pH}$, and $\mathrm{EC}$ were also recorded from grab samples. The water samples taken for dye analyses were kept in amber vials in order to minimize photodegradation.

\subsubsection{Winter Baseflow Traces}

Two dye injections were conducted on December 5, 2018. At 10:35 am, 1.8 kg of eosine dye dissolved in $\sim 100 \mathrm{~L}$ of water and flushed with another $~ 50 \mathrm{~L}$ of water was injected at Sanjianfang (location \#123) (Figure 14). At 11:25 am, $1.8 \mathrm{~kg}$ of sulforhodamine B dissolved in $100 \mathrm{~L}$ of water and flushed with another $~ 50 \mathrm{~L}$ of water was injected at Daxing (location \#121) (Figure 14). These two dye injections began at 
baseflow, with the last recorded precipitation event $>0.2 \mathrm{~mm} / \mathrm{hr}$ occurring 19 days prior (November 16), and because they were conducted during the dry season, water levels at both locations were significantly lower than those observed during the summer.

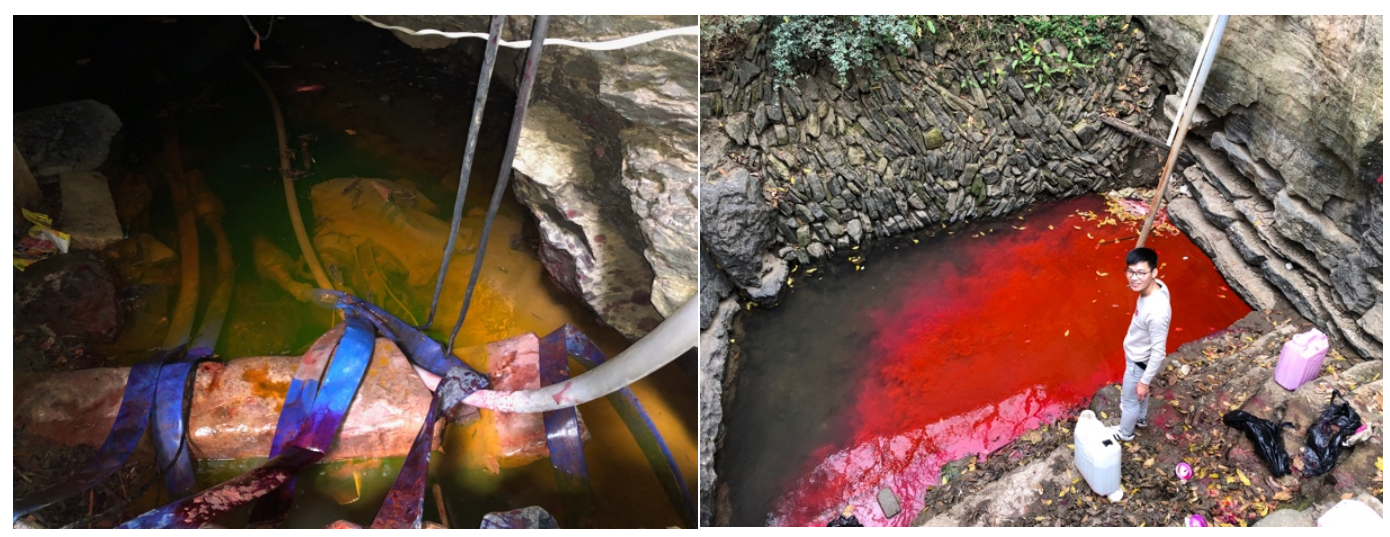

Figure 14: Field photographs showing winter baseflow dye injections at Sanjianfang (left) and Daxing (right).

\subsubsection{Bug/Dye Testing}

The charcoal bugs were analyzed for dye following Currens (2013). First, $5 \mathrm{~g}$ of activated charcoal was measured out from each bug into a labeled condiment cup. Smart solution, a mixture of 50\% 1-propanol, $20 \%$ concentrated $\mathrm{NH}_{4} \mathrm{OH}$, and $30 \%$ distilled water by volume, was added to the cup to cover the charcoal and a lid was placed on the cup to minimize evaporation in the fume hood. The charcoal and solution were left to soak for $1 \mathrm{~h}$ and then the eluent was decanted into cuvettes to be tested using the KGS spectrofluorometer (Figure 15). All summer bugs were scanned for both fluorescein and eosine and all winter bugs were scanned for both sulforhodamine B and eosine. 

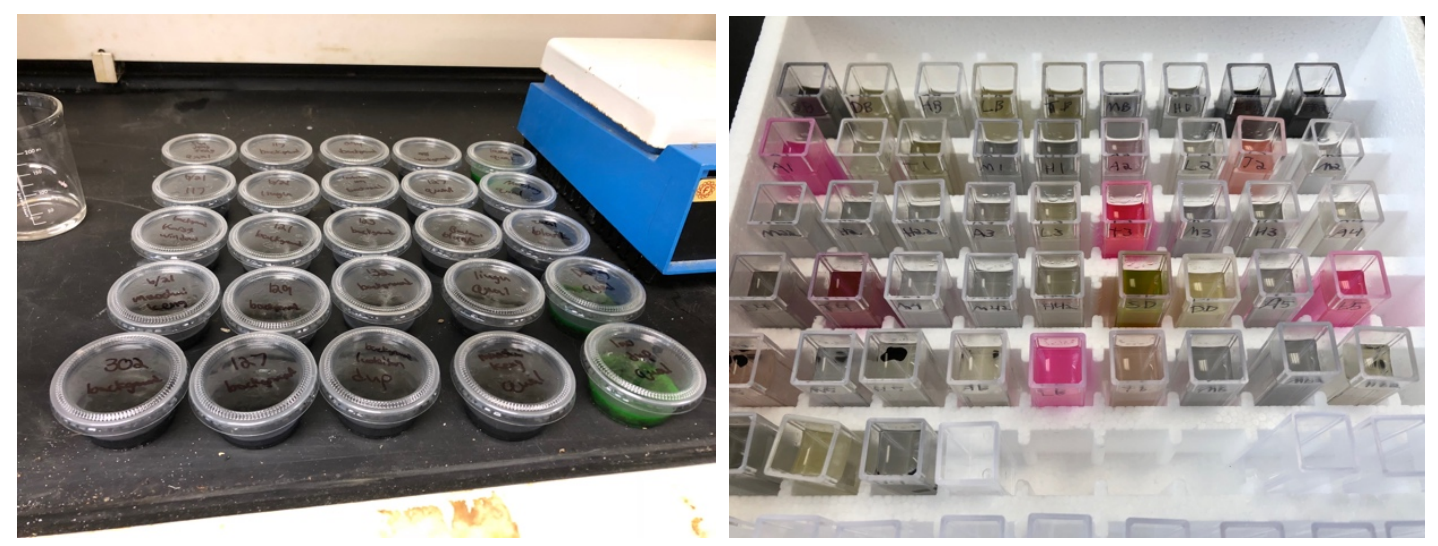

Figure 15: Images showing charcoal from the bugs during elution in containers of smart solution (left) and vials of eluent ready to be tested by a spectrofluorometer (right).

Water samples taken from Maoshuikeng after the summer stormflow dye injection were tested for dye at Guizhou Minzu University, but the detection limit (DL) of the spectrofluorometer was too high. Standards made from dissolving dye in the lab were used to construct a calibration curve, which showed a DL of 1 ppm for eosine. Therefore, the remaining sample volume was transported back to Kentucky for analyses at KGS. The samples were analyzed at the emission wavelength of eosine and several samples were scanned over a wider range to look for other peaks. In addition, approximately $10 \mathrm{~mL}$ of smart solution was poured into the empty $40-\mathrm{mL}$ glass sample vials in an attempt to extract any dye that might have sorbed onto the glass. The smart solution was left in the vials for $1 \mathrm{~h}$ and then tested. 


\subsection{Solute and Isotope Analyses}

Anion and metal(loid) analyses were performed at the Institute of Geochemistry, Chinese Academy of Sciences, in Guiyang. Anions were measured using ion chromatography, while cations and $\mathrm{SiO}_{2}{ }^{0}$ were measured using inductively coupled plasma optical emission spectrometry (ICP-OES). Five anion samples were retested using ion chromatography in the Department of Plant and Soil Sciences at the University of Kentucky as a comparison. Stable isotope analyses for carbon-13 of dissolved inorganic carbon (DIC) were performed at the Institute of Geochemistry using a Thermo Fisher Scientific MAT 252 instrument. The data are reported as $\delta^{13}$ CDIC in per mille (\%o) notation relative to Vienna Pee Dee Belemnite (VPDB). Water isotopes $\left(\delta^{18} \mathrm{O}\right.$ and $\left.\delta^{2} \mathrm{H}\right)$ were measured in the Kentucky Stable Isotope Geochemistry Laboratory at the University of Kentucky by cavity ring-down spectroscopy (CRDS) with a Los Gatos instrument. In order to test the reproducibility of the results, every sample was duplicated. The data are reported in per mille notation relative to Vienna Standard Mean Ocean Water (VSMOW).

Solute data and additional water parameters, including alkalinity, temperature, and $\mathrm{pH}$, were entered into the geochemical modeling program PHREEQC (Version 3.4.0 with phreeqc.dat database file) to calculate charge balances for each water sample (85\% of the water samples charge- balanced to within $2 \%$ error and the largest error was $<5 \%$ ) and saturation indices for phases of interest, including calcite $\left(\mathrm{CaCO}_{3}\right)$, dolomite $\left(\mathrm{CaMg}\left(\mathrm{CO}_{3}\right)_{2}\right)$, strontianite $\left(\mathrm{SrCO}_{3}\right)$, gypsum $\left(\mathrm{CaSO}_{4} \cdot 2 \mathrm{H}_{2} \mathrm{O}\right)$, and celestite $\left(\mathrm{SrSO}_{4}\right)$. 


\section{CHAPTER 3. RESULTS}

\subsection{Synoptic Sampling}

Physical and chemical water parameters fluctuated spatially and temporally throughout the Houzhai catchment. Not surprisingly, water temperatures are generally cooler during the winter and warmer during the summer (Figure 16). However, Xiao Shanba (location \#98) and Maokeng (location \#302) seem to experience a larger range in water temperatures as compared to the other karst features (Figure 16). EC and carbonate alkalinity values were generally higher during in the upper (southeast) part of the catchment and during the winter (Figures 17 and 19). $\mathrm{pH}$ was also higher during the winter, but without a definitive spatial trend (Figure 18). The $\mathrm{Na}^{+}$and $\mathrm{Cl}^{-}$concentrations at Xiao Shanba (35.01 mg/L and $57.34 \mathrm{mg} / \mathrm{L}$ respectively) were anomalously high during the winter. $\mathrm{Mg} / \mathrm{Ca}$ ratios were generally higher during the winter, especially at Maokeng and Maoshuikeng (Figure 20). $\delta^{13}$ CDIC values tended to be higher during the winter, especially in the upper part of the catchment, whereas the opposite trend holds for $\delta^{2} \mathrm{H}$ and $\delta^{18} \mathrm{O}$ values (Figures 21, 22, and 23). 
Table 1: Ranges of summer and winter synoptic sample field parameters and analytes.

\begin{tabular}{|c|c|c|}
\hline Field Parameter or Analyte & Summer & Winter \\
\hline $\mathrm{T}\left({ }^{\circ} \mathrm{C}\right)$ & $17.64-22.94$ & $14.81-17.76$ \\
\hline $\mathrm{EC}(\mu \mathrm{S} / \mathrm{cm})$ & $0.498-0.643$ & $0.443-0.870$ \\
\hline $\mathrm{pH}$ & $6.77-8.10$ & $6.72-7.36$ \\
\hline Carbonate Alkalinity (mg/L $\left.\mathrm{CaCO}_{3}\right)$ & $141-192$ & $190-257$ \\
\hline $\mathrm{Ca}^{2+}(\mathrm{mg} / \mathrm{L})$ & $61.09-93.93$ & $59.92-117.89$ \\
\hline $\mathrm{K}^{+}(\mathrm{mg} / \mathrm{L})$ & $2.32-8.70$ & $1.11-11.20$ \\
\hline $\mathrm{Mg}^{2+}(\mathrm{mg} / \mathrm{L})$ & $10.67-19.20$ & $22.91-28.17$ \\
\hline $\mathrm{Na}^{+}(\mathrm{mg} / \mathrm{L})$ & $1.87-6.08$ & $1.97-35.01$ \\
\hline $\mathrm{SiO}_{2}{ }^{0}(\mathrm{mg} / \mathrm{L})$ & $4.32-9.34$ & $3.01-5.45$ \\
\hline $\mathrm{Sr}^{2+}(\mathrm{mg} / \mathrm{L})$ & $0.98-2.30$ & $0.27-3.82$ \\
\hline $\mathrm{Mg} / \mathrm{Ca}$ & $0.21-0.45$ & $0.35-0.69$ \\
\hline$\delta^{13}$ CDIC (\%o PDB) & $-13.21--8.71$ & $-12.27--8.82$ \\
\hline$\delta^{2} \mathrm{H}(\%$ VSMOW) & $-67.1--47.5$ & $-57.0--52.0$ \\
\hline$\delta^{18} \mathrm{O}(\%$ VSMOW) & $-9.76--6.89$ & $-8.36--7.41$ \\
\hline $\mathrm{F}^{-}(\mathrm{mg} / \mathrm{L})$ & $0.18-0.34$ & $0.19-0.78$ \\
\hline $\mathrm{Cl}^{-}(\mathrm{mg} / \mathrm{L})$ & $6.30-12.82$ & $4.79-57.34$ \\
\hline $\mathrm{NO}_{3}^{-}(\mathrm{mg} / \mathrm{L})$ & $13.74-27.56$ & $14.52-20.72$ \\
\hline $\mathrm{SO}_{4}^{2-}(\mathrm{mg} / \mathrm{L})$ & $46.63-110.63$ & $28.20-191.28$ \\
\hline $\mathrm{NO}_{2}^{-}(\mathrm{mg} / \mathrm{L})$ & $0.03-0.53$ & $<0.05$ \\
\hline $\mathrm{Br}^{-}(\mathrm{mg} / \mathrm{L})$ & $<0.2$ & $<0.2$ \\
\hline
\end{tabular}



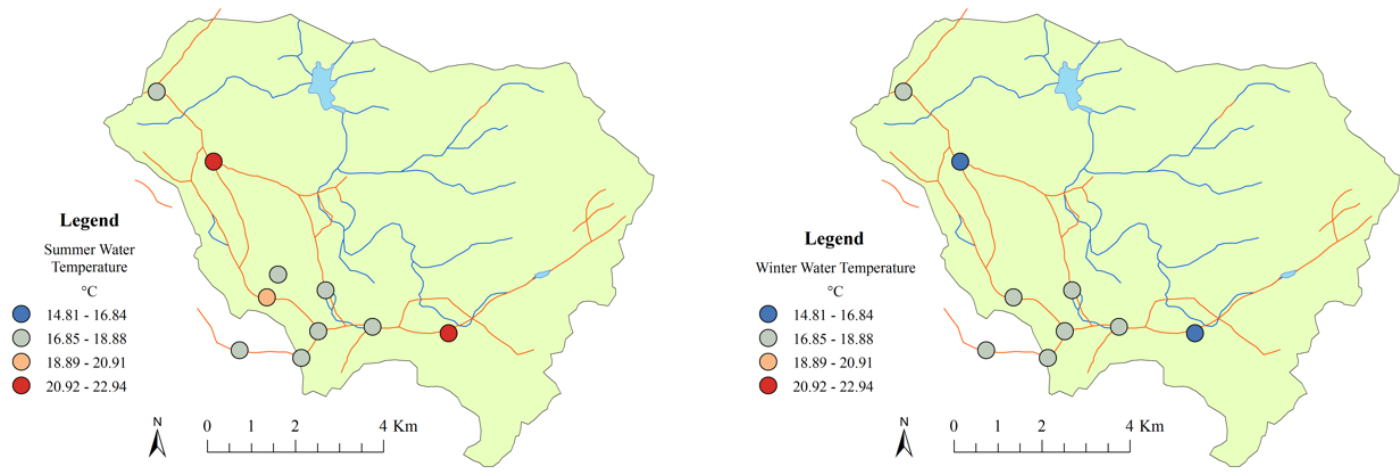

Figure 16: Maps comparing synoptic water temperature. Warmer colors correspond to a higher water temperature. Summer samples are on the left, winter samples are on the right. Data from YSI 556 probe.
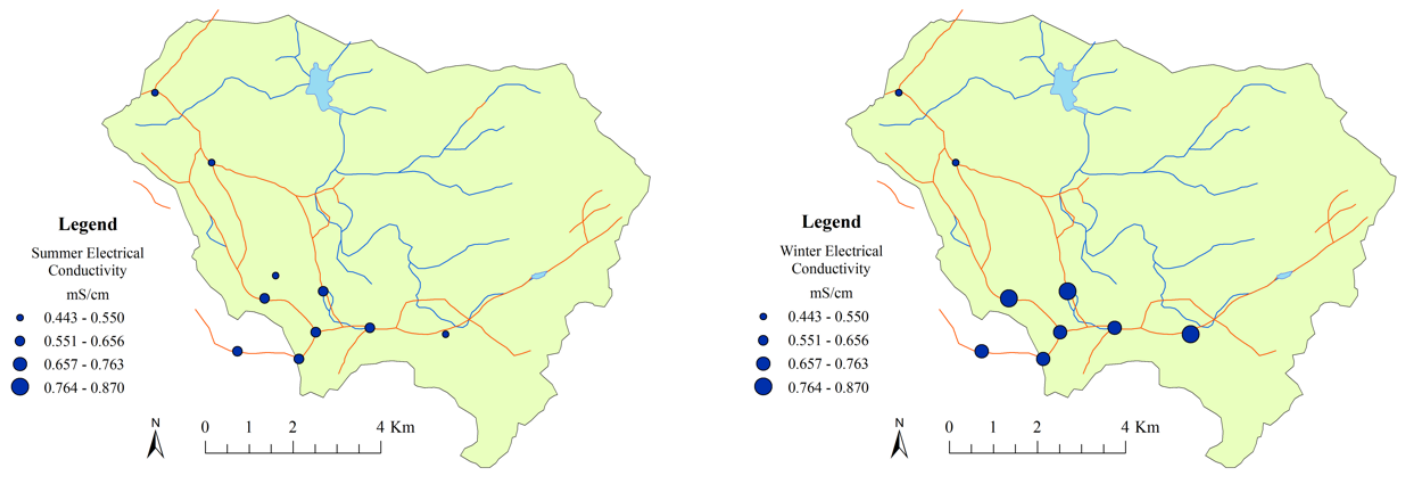

Figure 17: Maps comparing synoptic EC. Larger point diameter corresponds to a higher electrical conductivity. Summer samples are on the left, winter samples are on the right. Data from YSI 556 probe. 

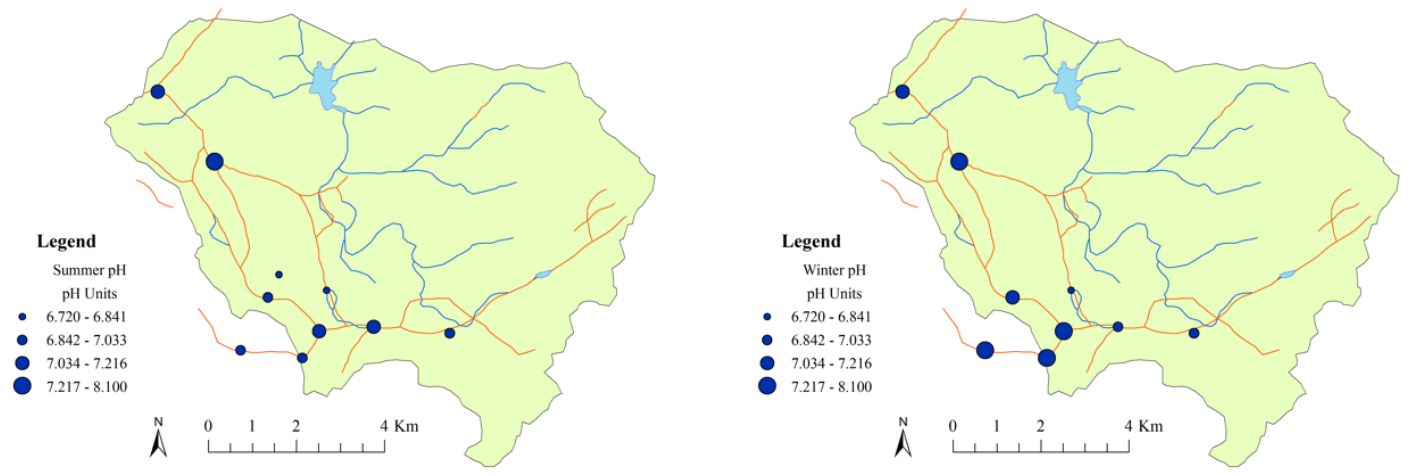

Figure 18: Maps comparing synoptic water sample $\mathrm{pH}$. Larger point diameter corresponds to a higher $\mathrm{pH}$. Summer samples are on the left, winter samples are on the right.
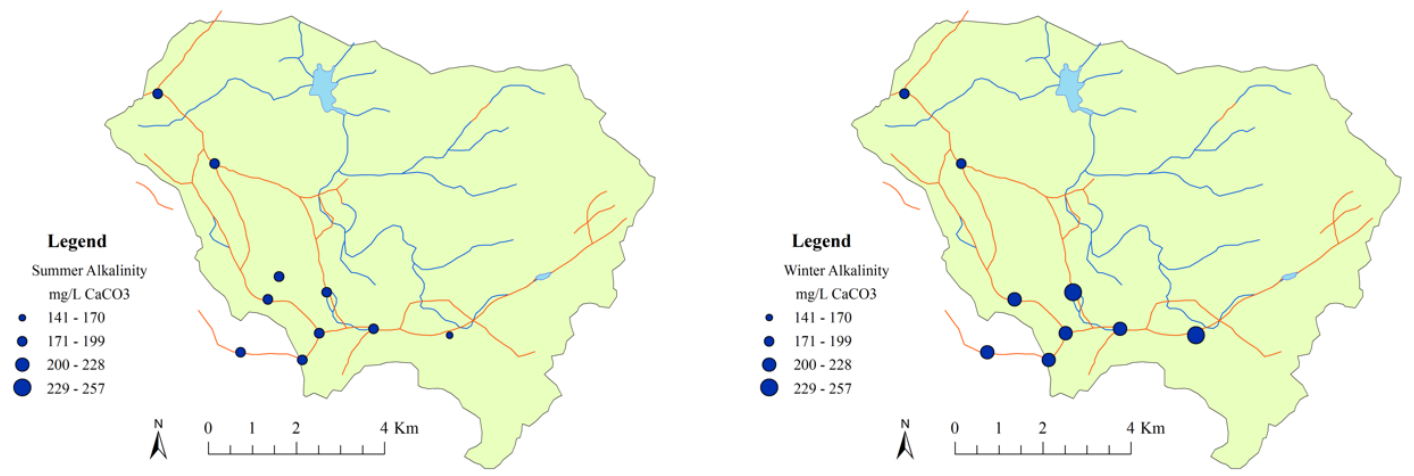

Figure 19: Maps comparing synoptic water sample carbonate alkalinity. Larger point diameter corresponds to a higher carbonate alkalinity. Summer samples are on the left, winter samples are on the right. 

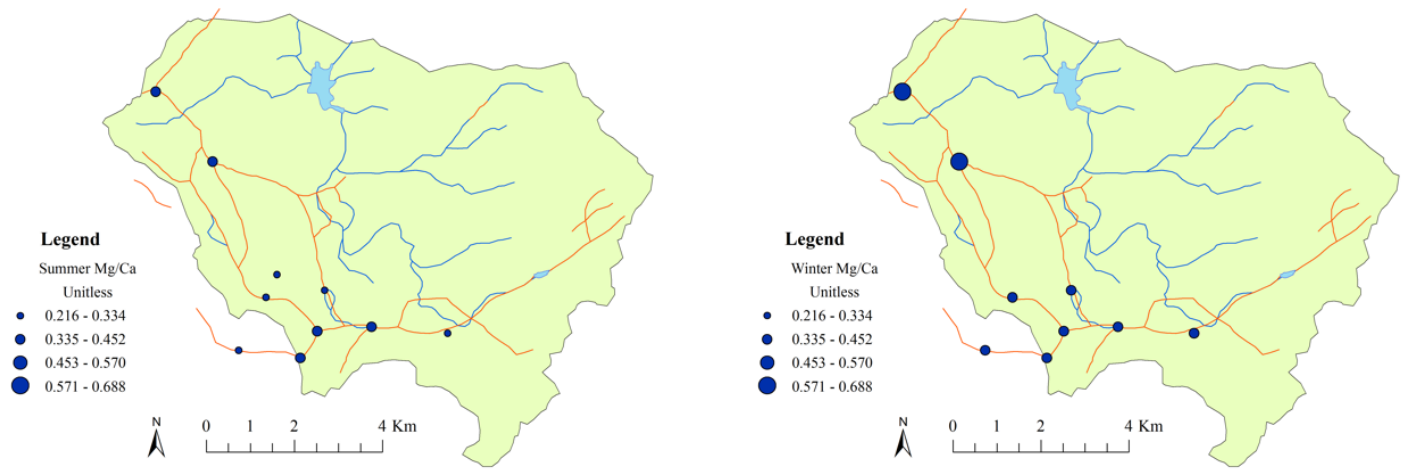

Figure 20: Maps comparing synoptic water sample Mg/Ca ratio. Larger point diameter corresponds to a higher $\mathrm{Mg} / \mathrm{Ca}$ ratio. Summer samples are on the left, winter samples are on the right.
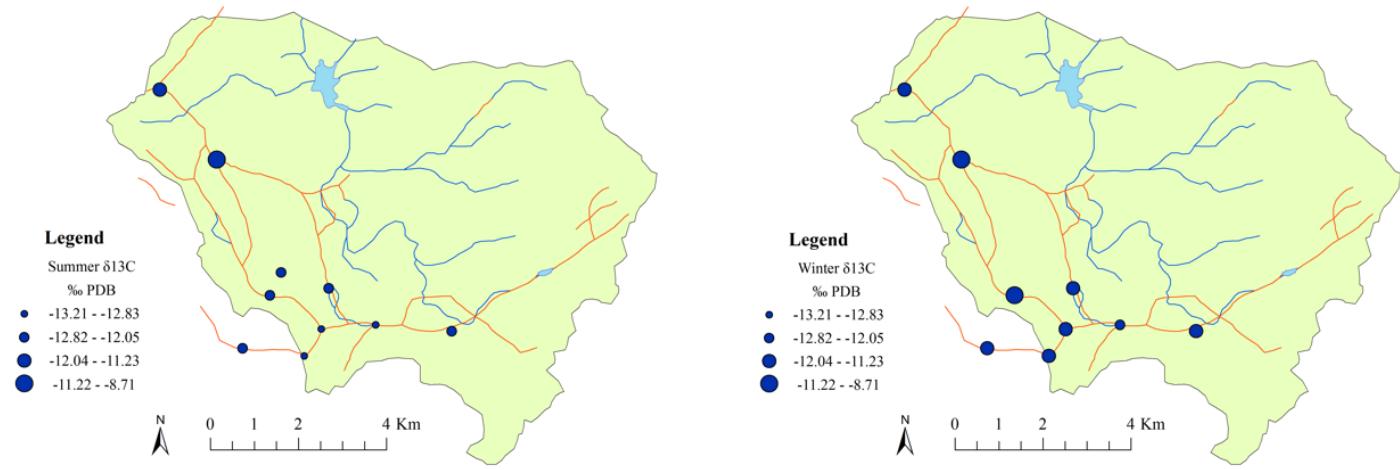

Figure 21: Maps comparing synoptic water sample $\delta^{13}$ CDIC values. Larger point diameter corresponds to a less negative $\delta^{13}$ CDIC value. Summer samples are on the left, winter samples are on the right. 

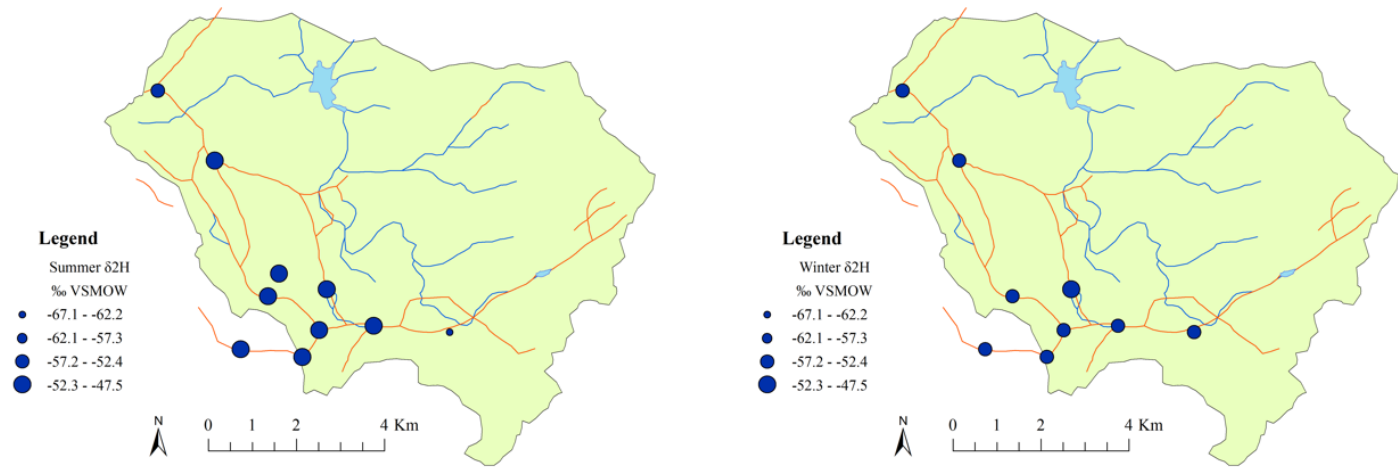

Figure 22: Maps comparing synoptic water sample $\delta^{2} \mathrm{H}$ values. Larger point diameter corresponds to a less negative $\delta^{2} \mathrm{H}$ value. Summer samples are on the left, winter samples are on the right.
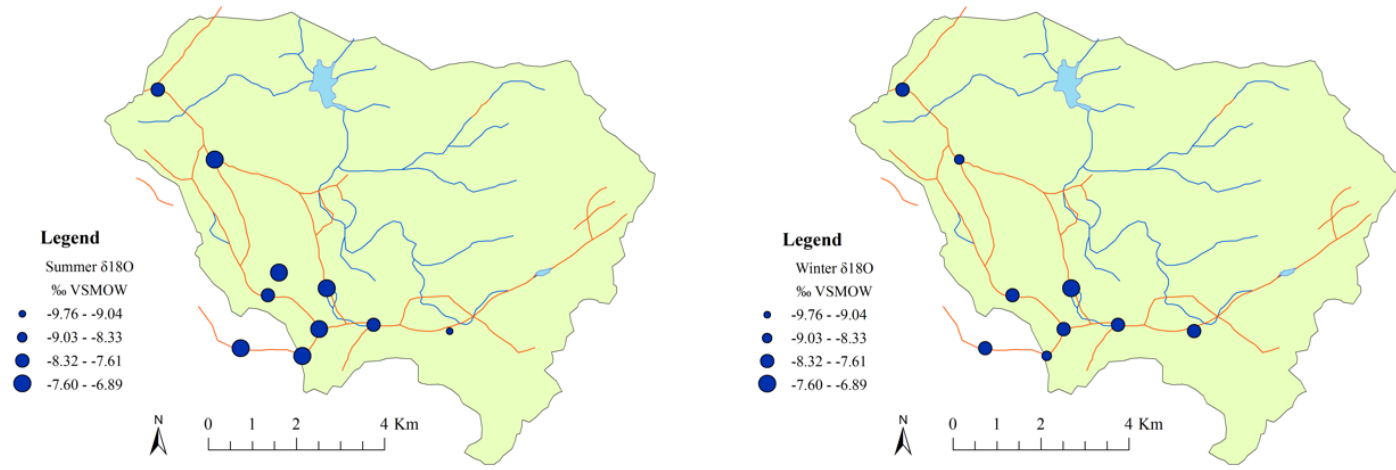

Figure 23: Maps comparing synoptic water sample $\delta^{18} \mathrm{O}$ value values. Larger point diameter corresponds to a less negative $\delta^{18} \mathrm{O}$ value. Summer samples are on the left, winter samples are on the right. 
$\mathrm{Ca}^{2+}$ is the dominant cation (Table 1). Its average baseflow concentrations of 75.1 $\mathrm{mg} / \mathrm{L}$ in summer and $95.9 \mathrm{mg} / \mathrm{L}$ in winter were approximately four times greater than those of $\mathrm{Mg}^{2+}$, the next most-abundant cation. $\mathrm{HCO}_{3}{ }^{-}$, the predominant carbonate species given the $\mathrm{pH}$ of this system, is the dominant anion, with $\mathrm{SO}_{4}{ }^{2-}$ the next most-abundant anion. This means that $\mathrm{Ca}-\mathrm{HCO}_{3}$ is the dominant hydrochemical facies. Piper diagrams constructed using the geochemical modeling software Geochemist’s Workbench (Version 12) (Figures 24 and 25) show that large-scale geochemical variability between samples is lacking, although $\mathrm{SO}_{4}{ }^{2-}$ concentrations were somewhat greater in winter synoptic samples (Figure 24).

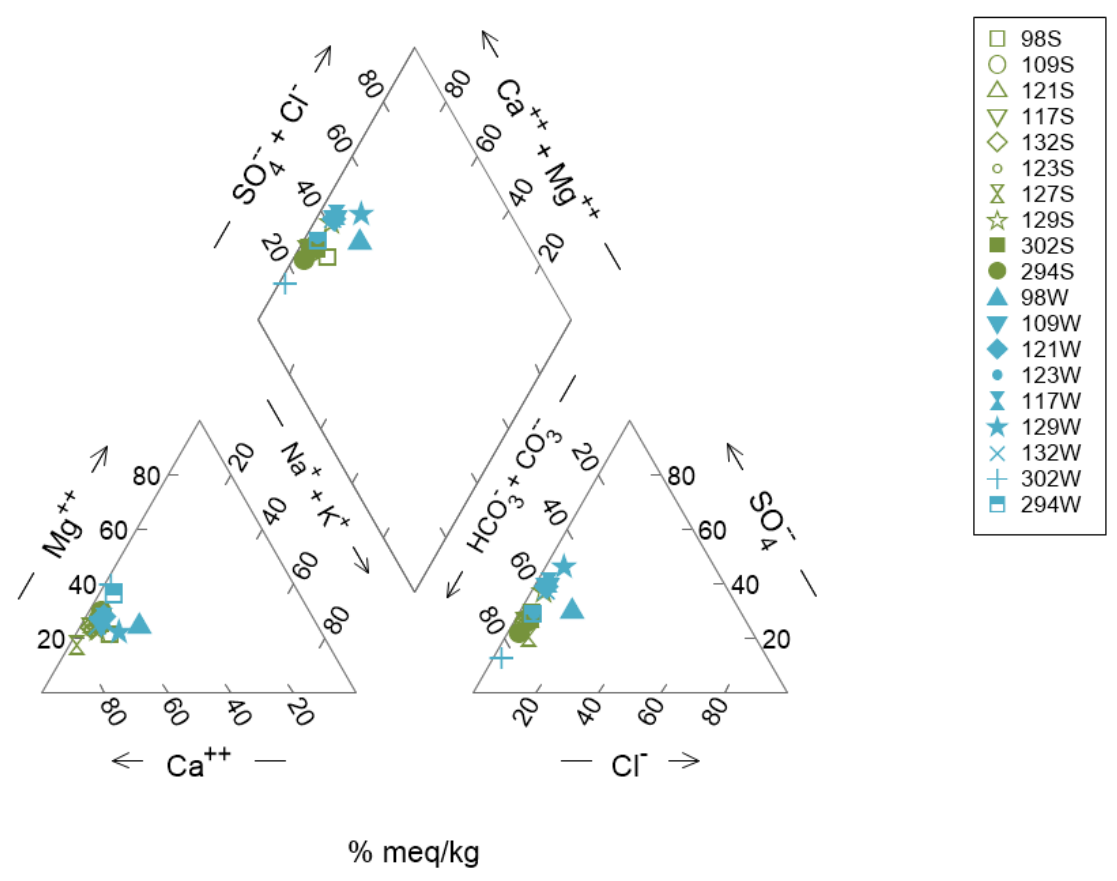

Figure 24: Piper diagram plotting summer and winter synoptic samples (green and blue, respectively). 


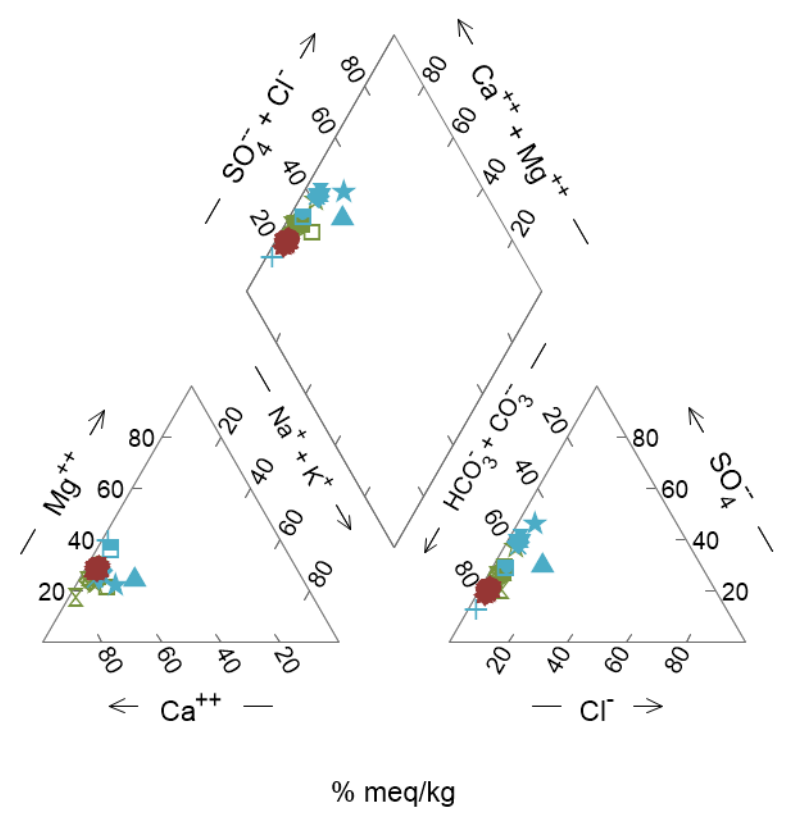

Figure 25: Piper diagram plotting summer synoptic samples (green), winter synoptic samples (blue), and summer time series samples (red).

On a plot of $\delta^{18} \mathrm{O}$ versus $\delta^{2} \mathrm{H}$ (Figure 26), the synoptic samples fall along the Global Meteoric Water Line (GMWL), with winter samples generally more depleted than summer samples. Nine of the summer samples clustered around average values of 50.8\% for $\delta^{2} \mathrm{H}$ and $-7.63 \%$ for $\delta^{18} \mathrm{O}$, but Xiao Shanba was considerably more depleted $\left(\delta^{2} \mathrm{H}=-67.1 \%\right.$ o, $\delta^{18} \mathrm{O}=-9.76 \%$ ) and Trash Spring was somewhat more enriched $\left(\delta^{2} \mathrm{H}=-\right.$ $47.5 \%$, $\delta^{18} \mathrm{O}=-6.89 \%$ ). Winter synoptic samples clustered around average values of 56.0\% for $\delta^{2} \mathrm{H}$ and $-8.17 \%$ for $\delta^{18} \mathrm{O}$, with only Sanjianfang significantly enriched $\left(\delta^{2} \mathrm{H}=\right.$ $-52.0 \%$, $\delta^{18} \mathrm{O}=-7.41 \%$ ). Maoshuikeng time series samples plot between winter and summer synoptic samples, with average values of $-52.4 \%$ for $\delta^{2} \mathrm{H}$ and $-7.82 \%$ for $\delta^{18} \mathrm{O}$, and no significant outliers (Figure 27). Of the three Daxing time series samples, two plot within the summer synoptic sample cluster, but the first sample, which was taken 
immediately following the stormflow dye trace, was significantly more enriched $\left(\delta^{2} \mathrm{H}=\right.$ $49.9 \%, \delta^{18} \mathrm{O}=-7.09 \%$ ).

A plot was also generated to compare the water isotope data collected in this thesis to the data published in Chen et al. (2018) (Figure 28). Overall, the Chen et al. (2018) data have a much larger range of recorded values, likely due to longer monitoring time, but average values tend to be more depleted in both $\delta^{2} \mathrm{H}$ and $\delta^{18} \mathrm{O}$, especially for precipitation data, than the samples collected as part of this thesis.

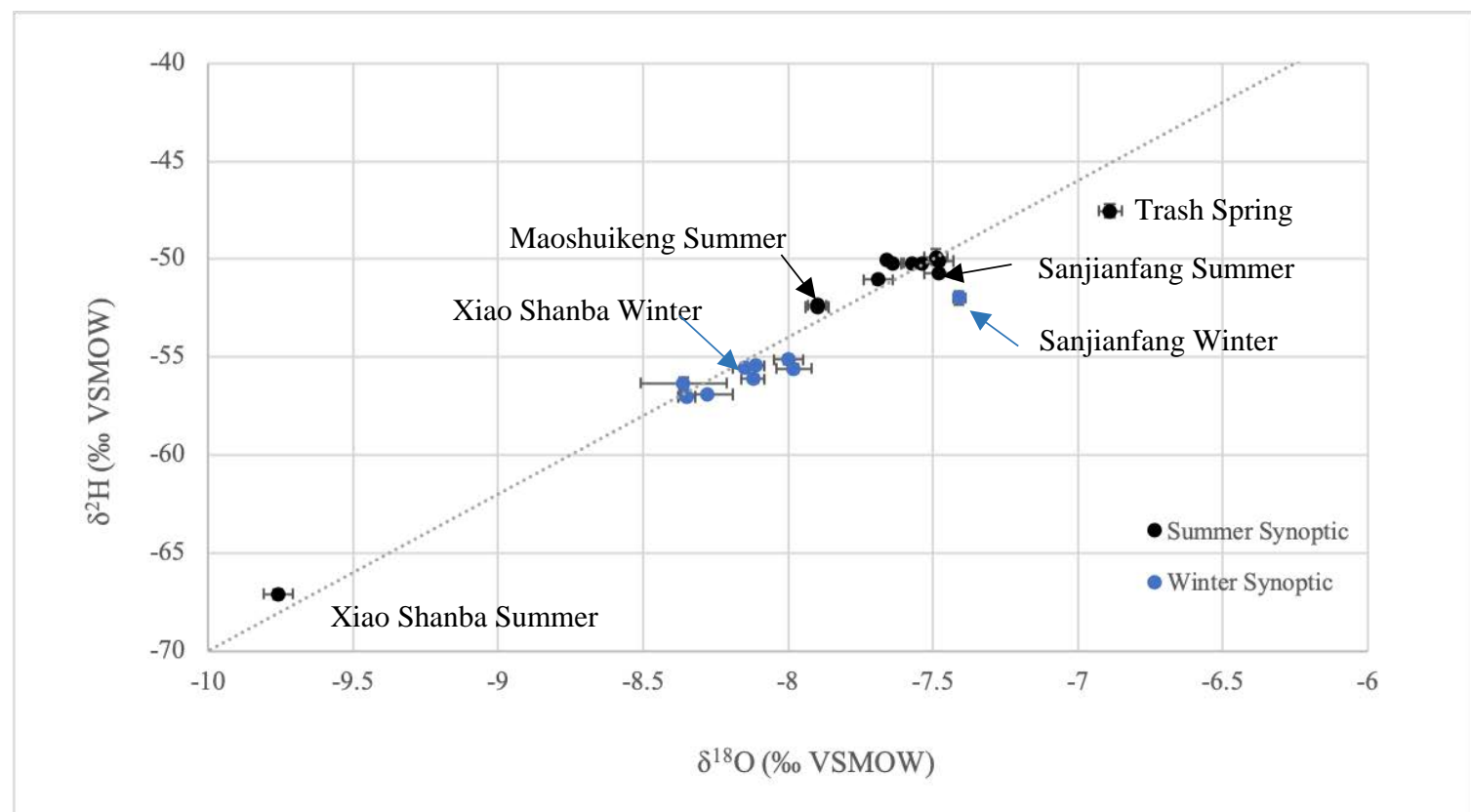

Figure 26: Plot of synoptic sample $\delta^{18} \mathrm{O}$ versus $\delta^{2} \mathrm{H}$ values relative to the Global Meteoric Water Line. Error bars represent standard deviations. 


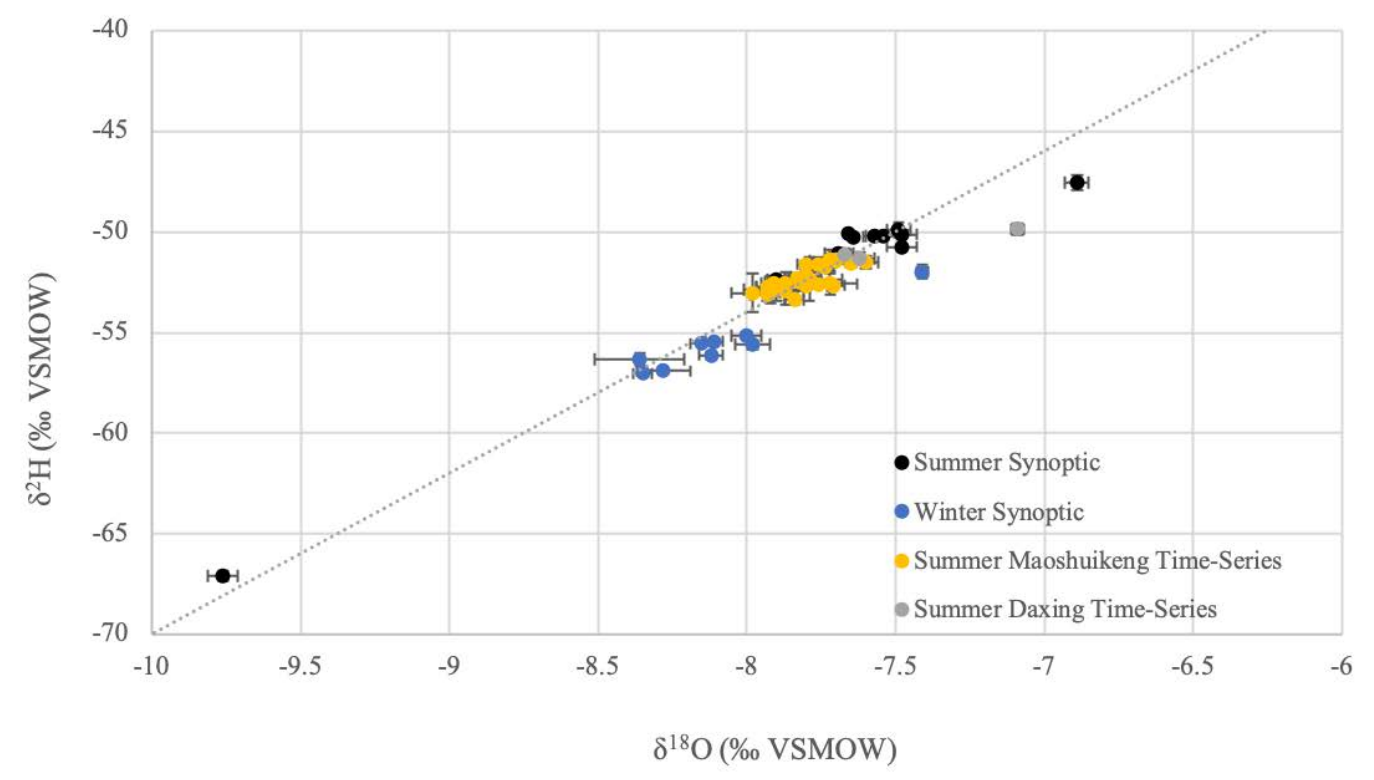

Figure 27: Plot of synoptic sample and time-series $\delta^{18} \mathrm{O}$ versus $\delta^{2} \mathrm{H}$ values relative to the Global Meteoric Water Line (dashed). Error bars represent standard deviations.

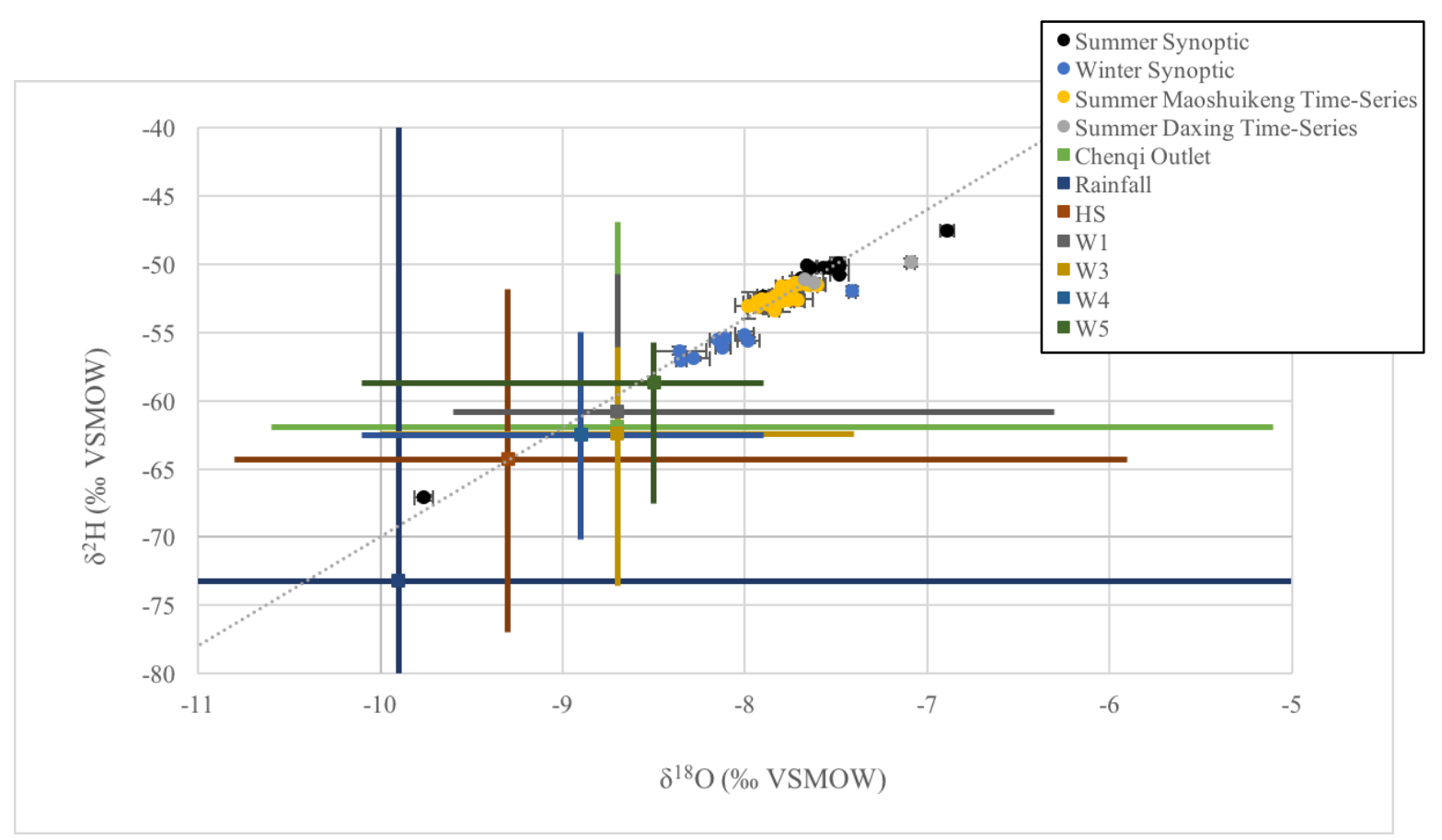

Figure 28: Plot of synoptic sample, time-series, and Chen et al. (2018) $\delta^{18} \mathrm{O}$ versus $\delta^{2} \mathrm{H}$ values relative to the Global Meteoric Water Line (dashed). Symbols for synoptic sample and time-series data are as in Figure 27. Error bars represent standard deviations; colored bars represent recorded data values. The isotopic range of the Chen et al. (2018) rainfall data $\left(\delta^{2} \mathrm{H}=-120.2 \%\right.$ o to $-17.9 \%$ o, $\delta^{18} \mathrm{O}=-16.4 \%$ o to $0 \%$ ) was too large to be plotted. 


\subsection{Time-Series Analysis}

The water level, EC, and T data collected at Laoheitan, Daxing, and Maoshuikeng in June show the arrival of several storm events (Figures 29, 30, and 31). Water level at Daxing was clearly more responsive to precipitation than Laoheitan and Maoshuikeng (Figure 29). There was also a slight lag in Maoshuikeng water level of approximately $3 \mathrm{~h}$ compared to Daxing, with regard to the rise starting June 23 (Figure 29). EC trends at Daxing and Laoheitan seemed to be more or less in phase, with lower EC values at Daxing (Figure 30). Compared with Daxing and Laoheitan, Maoshuikeng EC fluctuations were more muted (Figure 30). Likewise, water temperature at Laoheitan and Daxing exhibited strong diurnal cycles while the water temperature fluctuation at Maoshuikeng was more subdued (Figure 31).

The stormflow trace at Daxing occurred on June 23 at 1:00 pm, $3 \mathrm{~h}$ after water level at Maoshuikeng peaked (Figure 32). Therefore, the samples taken capture the falling limb of the storm event. Precipitation during this storm event, measured at the Laoheitan weather station, occurred in two main pulses. The first, with peak precipitation occurring at 3:30 pm June 21, measured $35.5 \mathrm{~mm}$ of rain, while the second, with peak precipitation occurring at 3:30 pm June 22, measured $24.1 \mathrm{~mm}$ of rain (Figure 33). A total of $6.5 \mathrm{~mm}$ of rainfall occurred after those two main pulses, with only $2.0 \mathrm{~mm}$ during the sampling period at Maoshuikeng. Manually-measured EC reached its minimum value at 9:35 am, nearly $24 \mathrm{~h}$ after the stage peak (Figure 34). Similarly, manually-measured water temperature, $\mathrm{pH}$, and several solutes $\left(\mathrm{Cl}, \mathrm{SO}_{4}, \mathrm{Na}, \mathrm{K}, \mathrm{Mg}, \mathrm{Sr}, \mathrm{SiO}_{2}\right)$ also reached minimum values $\sim 24 \mathrm{~h}$ after the stage peak. Approximately $6 \mathrm{~h}$ later, $\mathrm{Mg} / \mathrm{Ca}$ values reached their maximum after a clear increasing trend (Figure 48). Magnesium increased 
significantly during the afternoon and evening of the $24^{\text {th }}$. Alkalinity generally trended upward, while $\mathrm{NO}_{3}{ }^{-}$generally decreased over the sampling interval. There were no discernable trends for $\mathrm{F}$ or $\mathrm{Ca}$, nor for $\delta^{13} \mathrm{C}$ DIC, which fluctuated within $0.8 \%$ o (-11.55 to 12.34\%o). $\delta^{2} \mathrm{H}$ and $\delta^{18} \mathrm{O}$ fluctuated in tandem with one another (Figure 50). At the beginning of the sampling period, there was a steady increase in both values, followed by a sharp decrease during the first half of June 24, then a saw-shaped pattern of fluctuations.

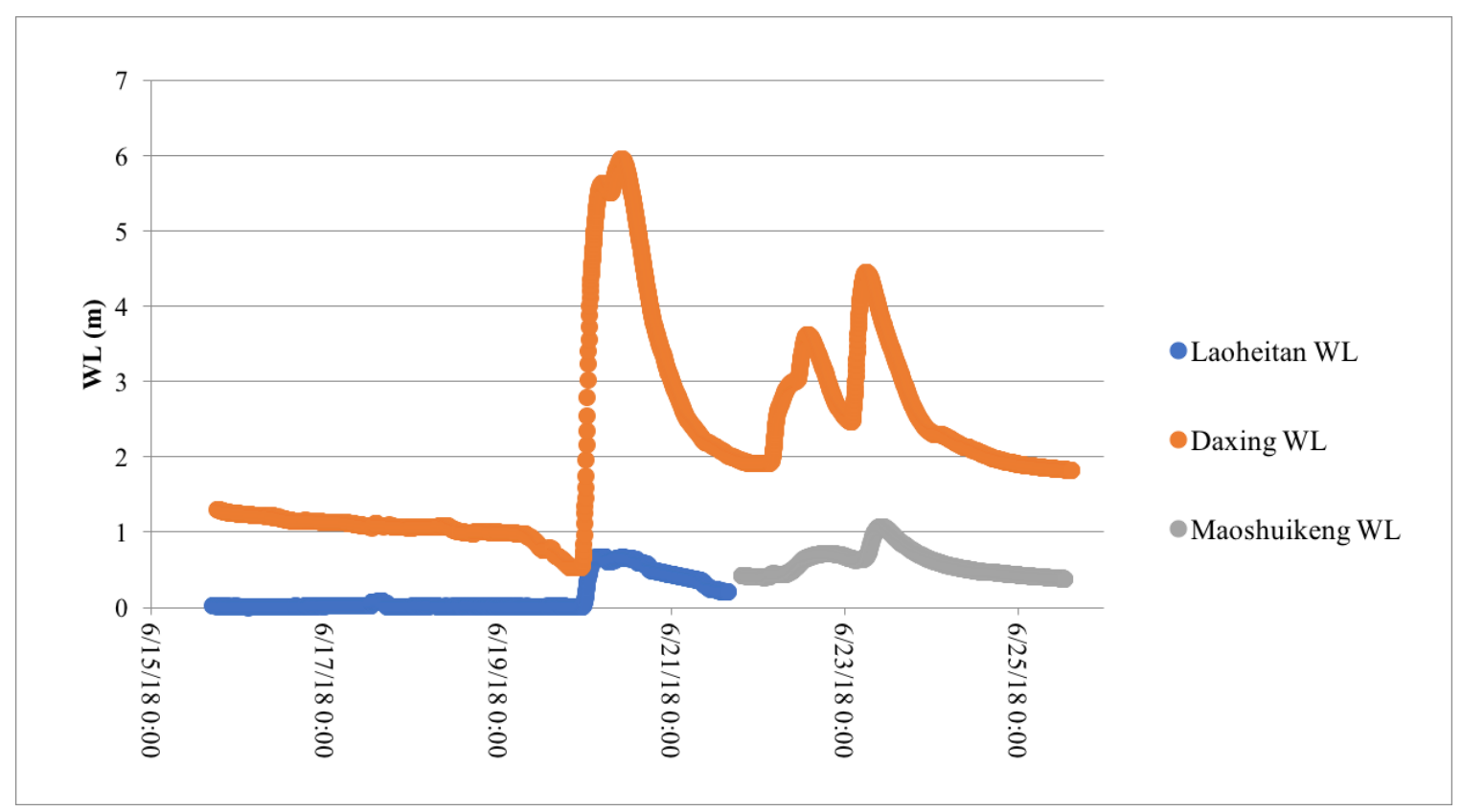

Figure 29: Plot showing continuously-logged relative water level data from Laoheitan, Daxing, and Maoshuikeng. 


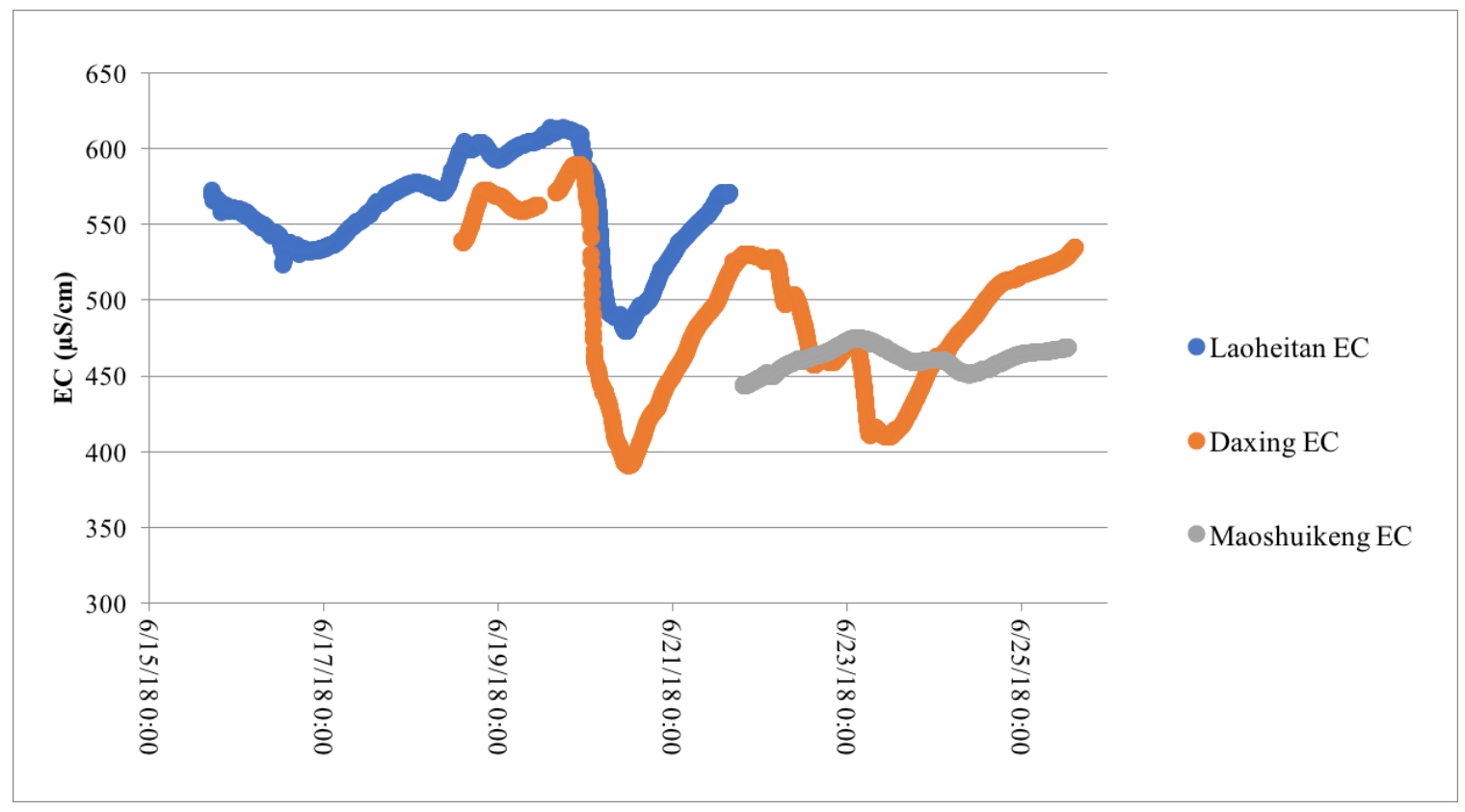

Figure 30: Plot showing continuously-logged electrical conductivity data from Laoheitan, Daxing, and Maoshuikeng.

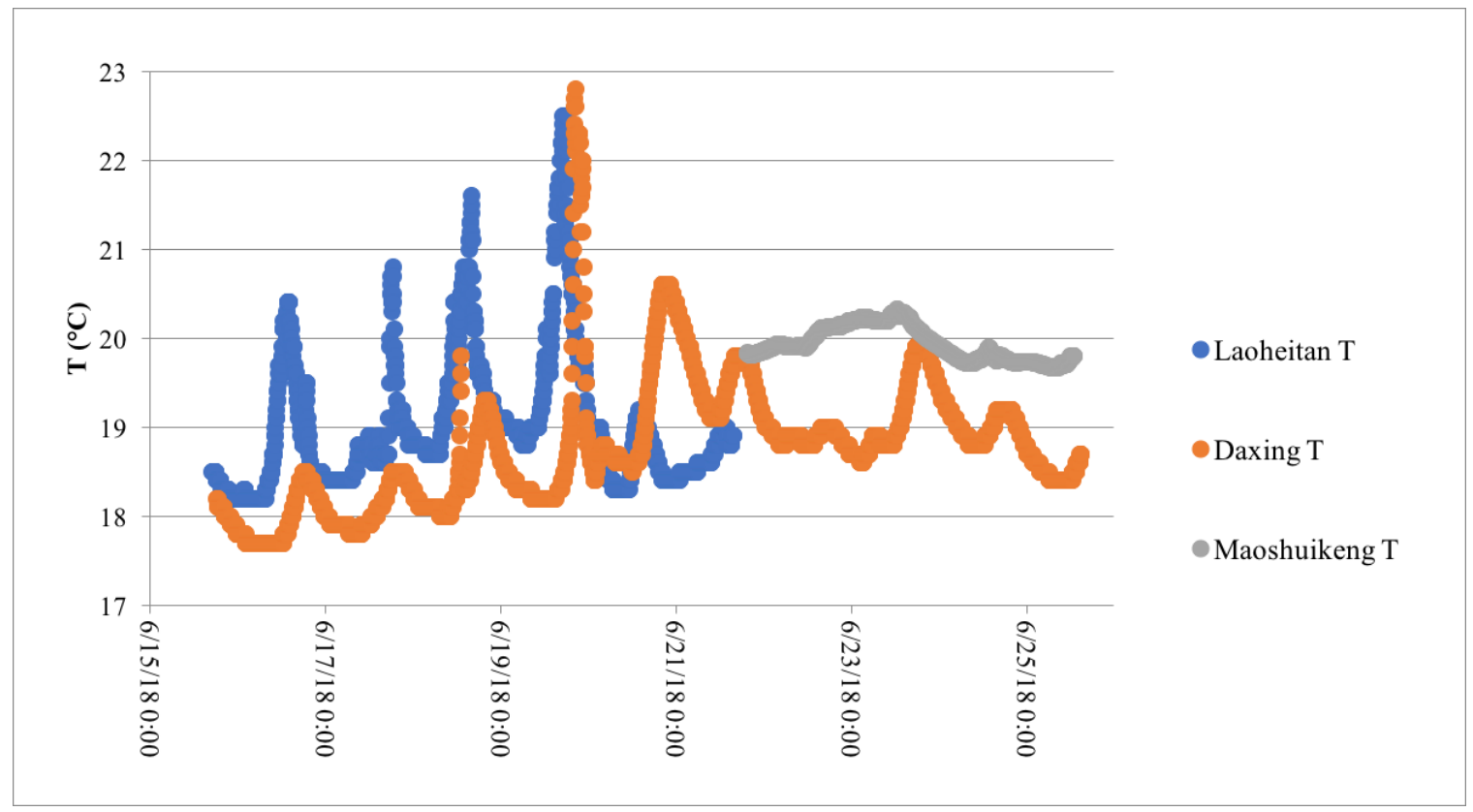

Figure 31: Plot showing continuously-logged temperature data from Laoheitan, Daxing, and Maoshuikeng. 


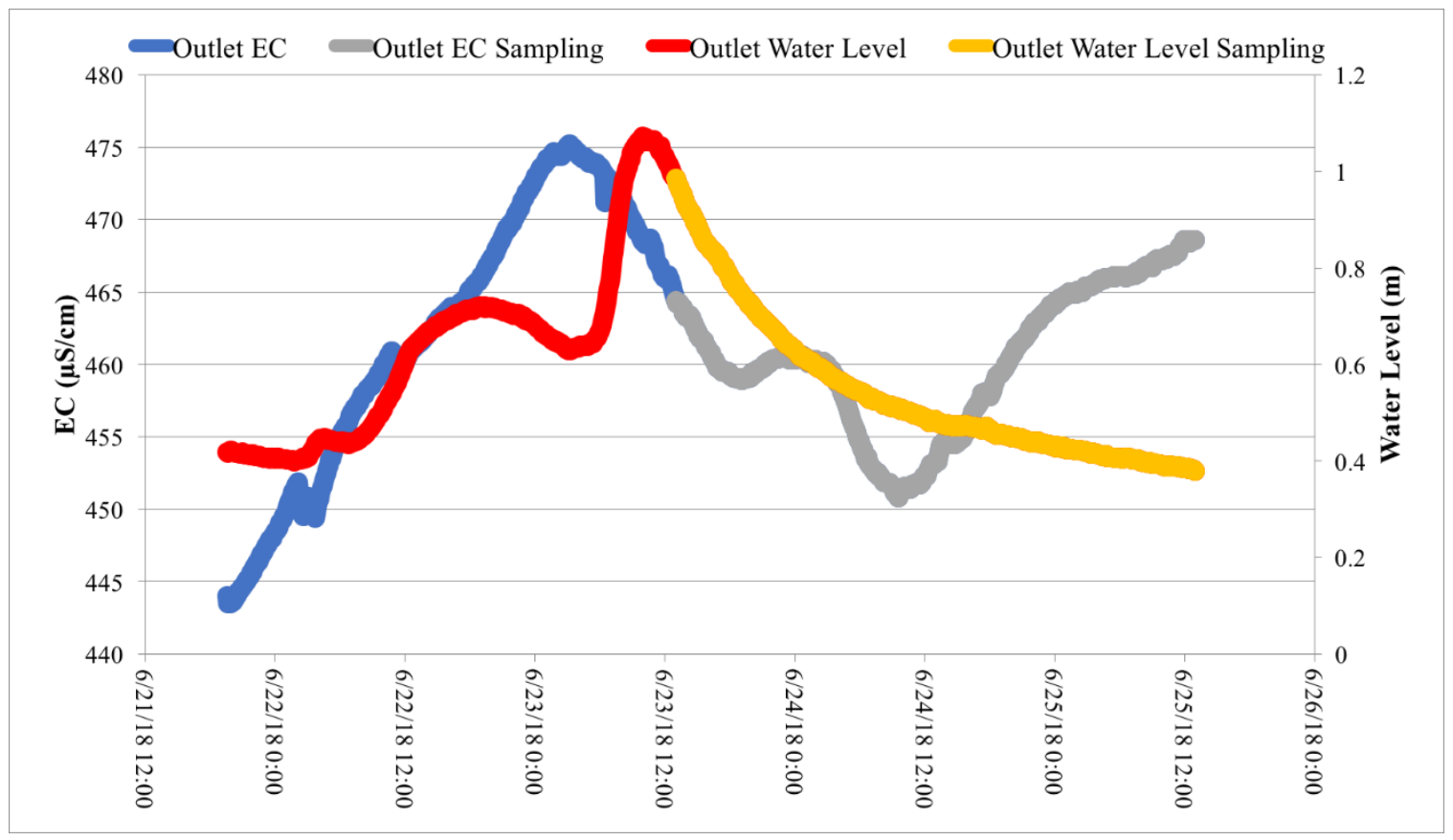

Figure 32: Plot showing continuously-logged EC and water level at Maoshuikeng leading up to the time of sampling (blue and red, respectively) and during the time of sampling (gray and yellow, respectively).

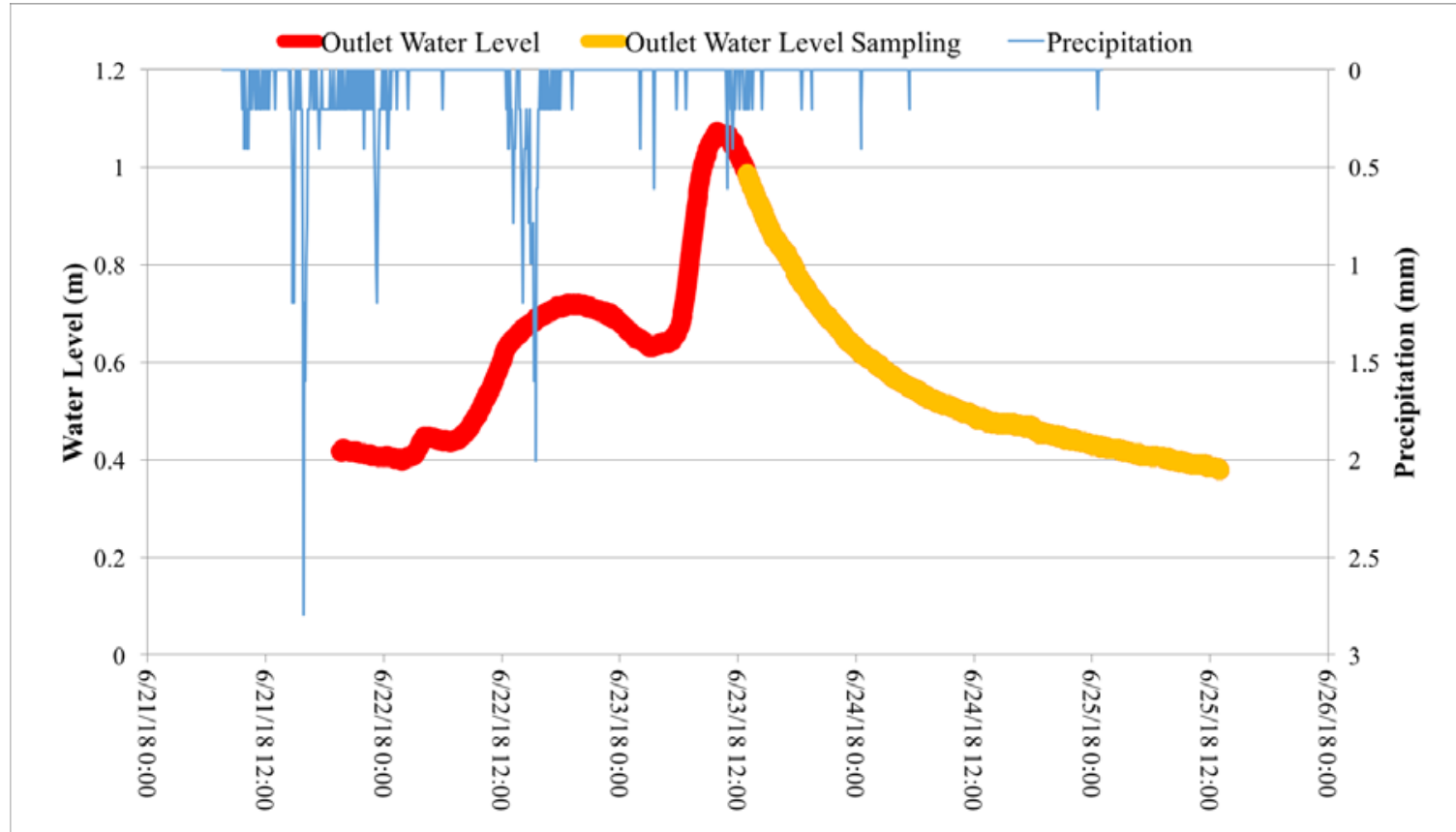

Figure 33: Plot showing water level at Maoshuikeng leading up to the time of sampling (red) and during the time of sampling (yellow) with precipitation data from Laoheitan weather station. 


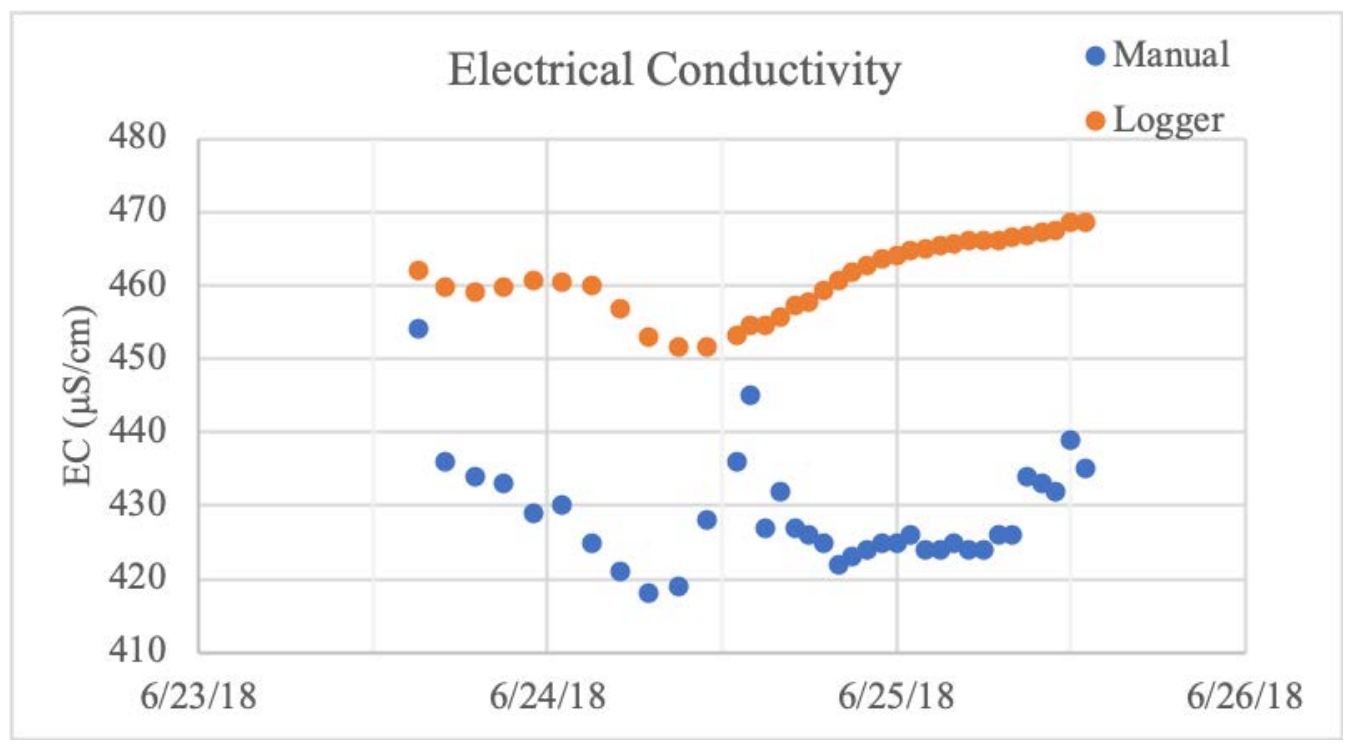

Figure 34: Plot showing electrical conductivity during time series sampling as measured manually and with a logger deployed $\sim 370$ m downstream along the spring run.

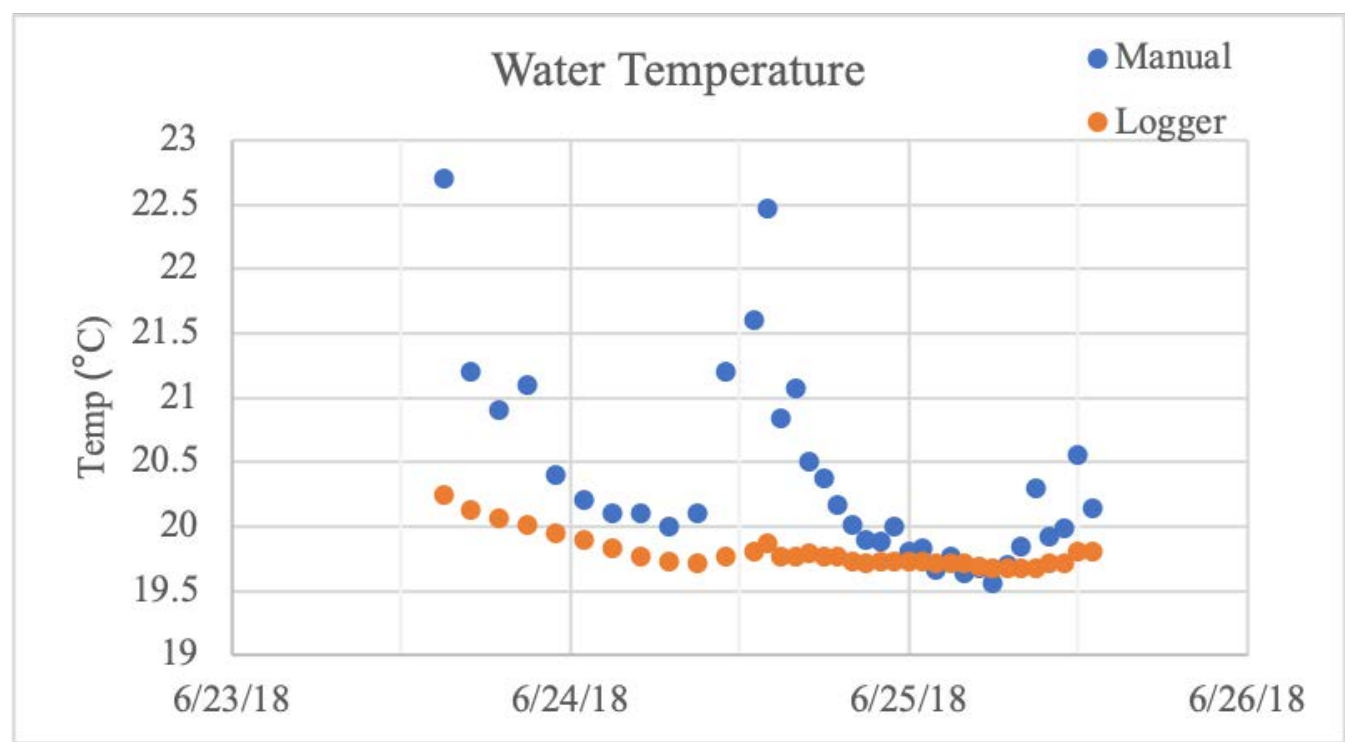

Figure 35: Plot showing water temperature during time series sampling as measured manually and with an automatic logger deployed $~ 370 \mathrm{~m}$ downstream along the spring run. 


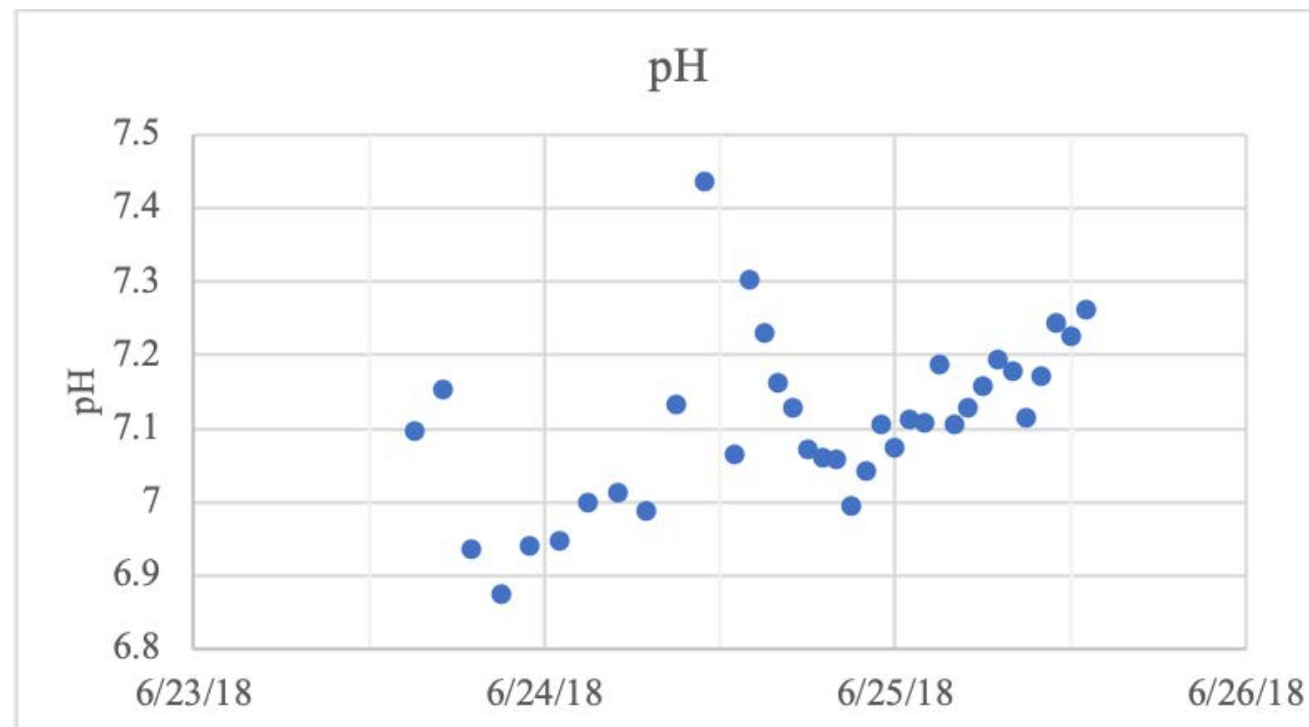

Figure 36: Plot showing $\mathrm{pH}$ during time series sampling.

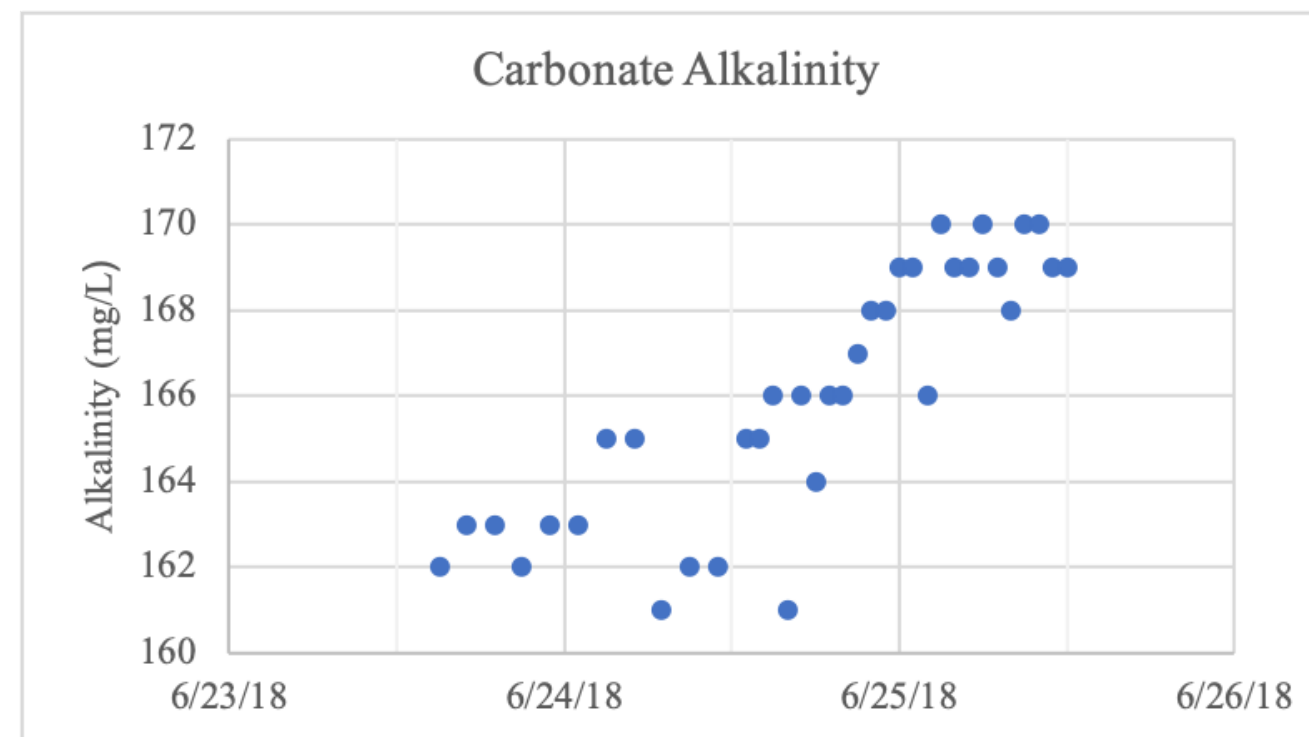

Figure 37: Plot showing carbonate alkalinity during time series sampling. 


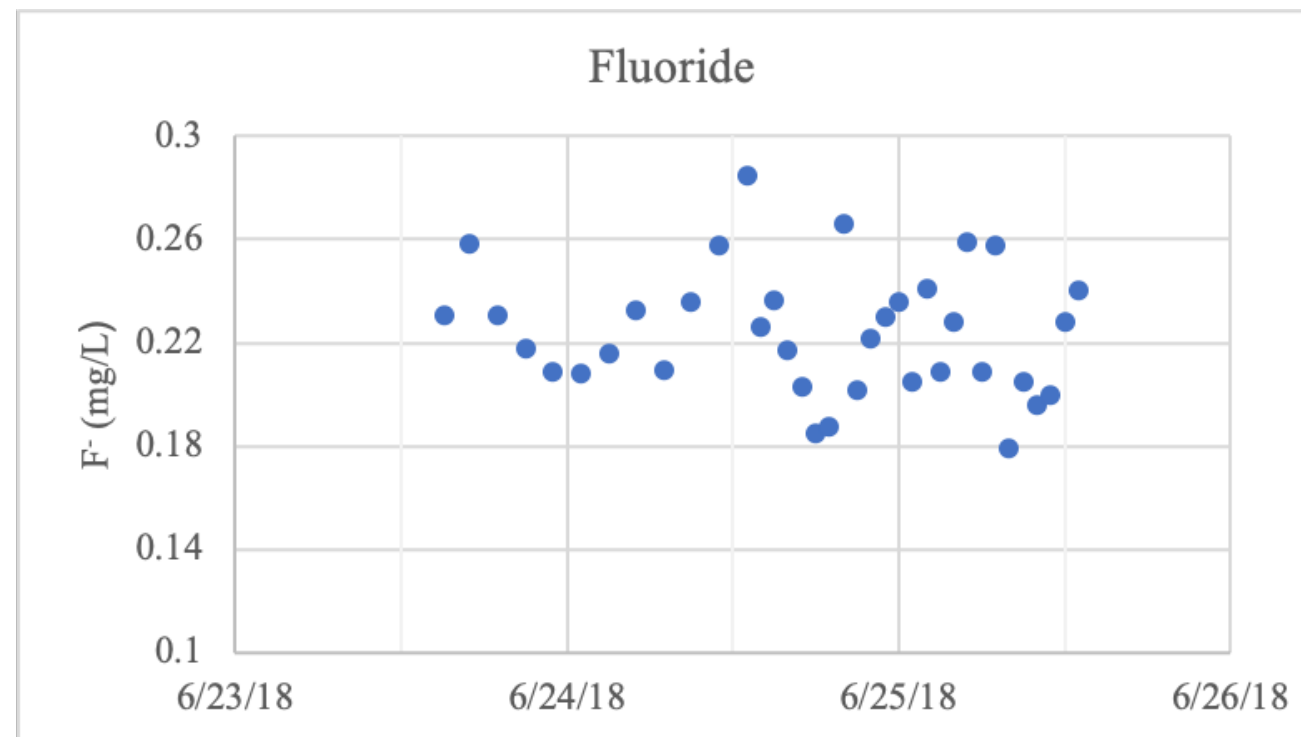

Figure 38: Plot showing fluoride concentration during time series sampling.

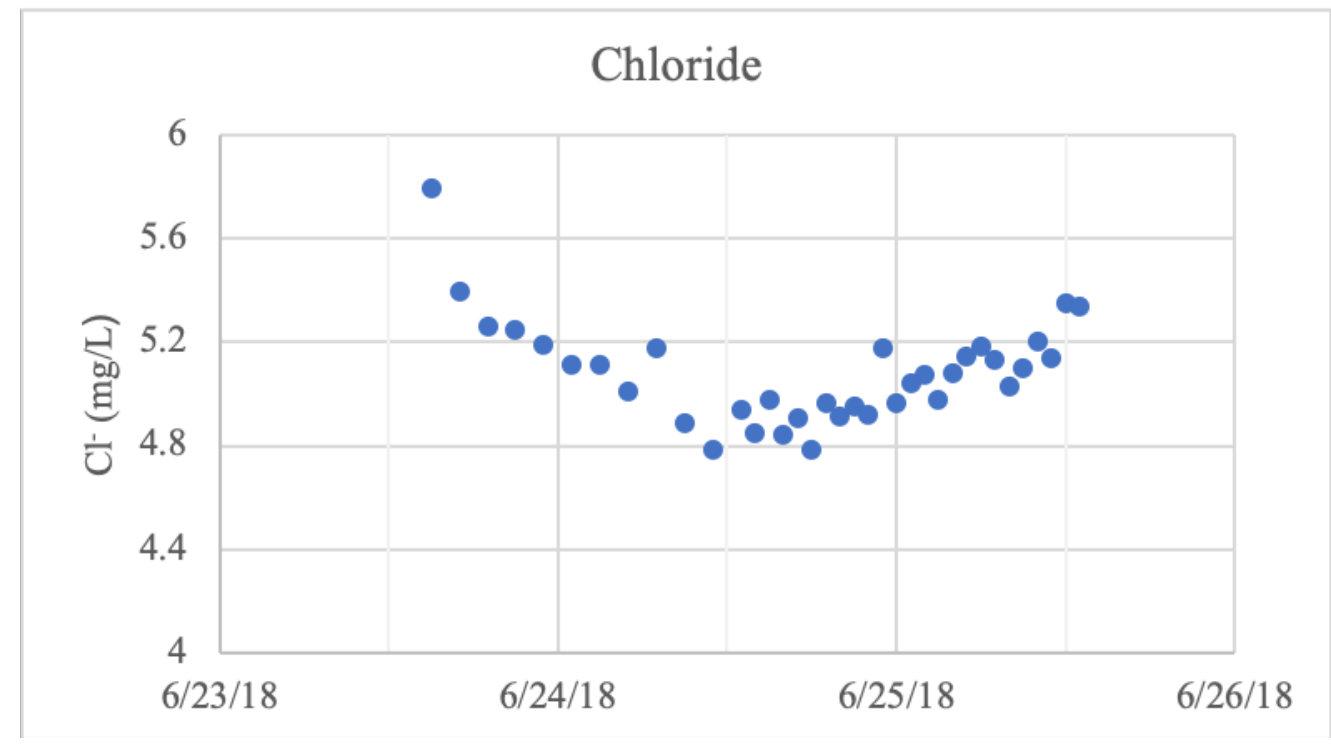

Figure 39: Plot showing chloride concentration during time series sampling. 


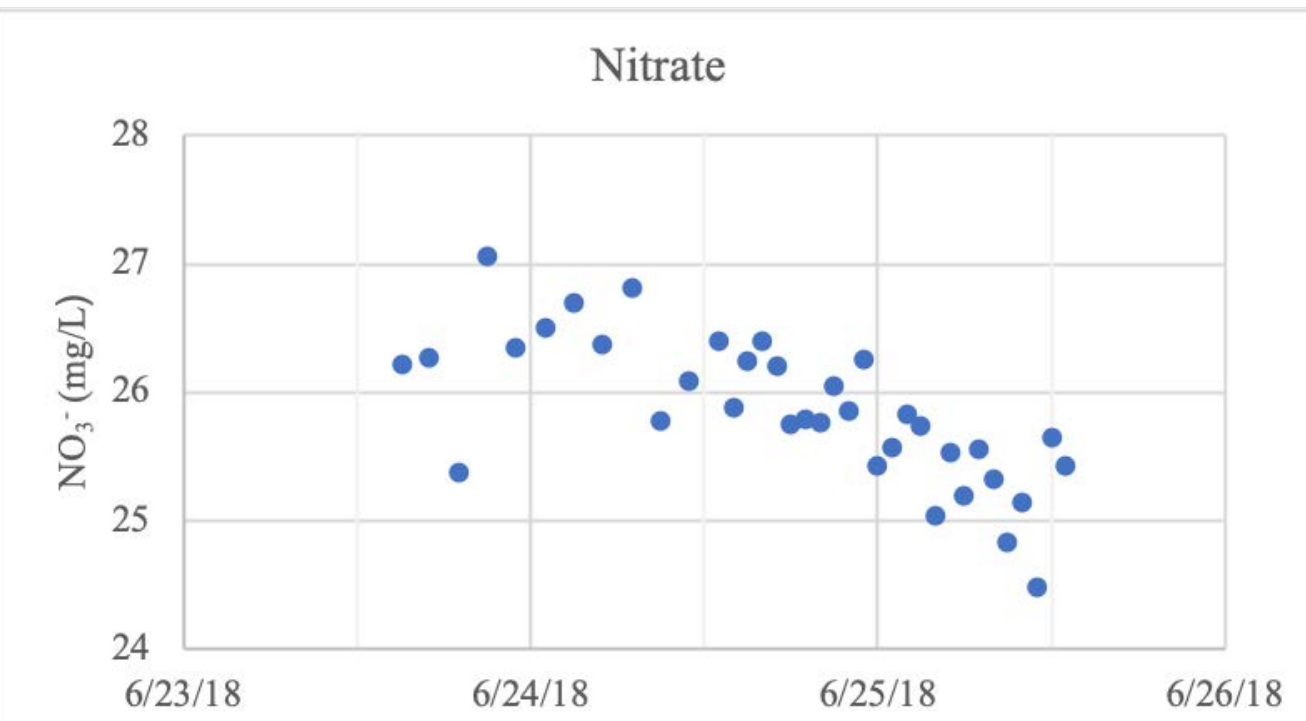

Figure 40: Plot showing nitrate concentration during time series sampling.

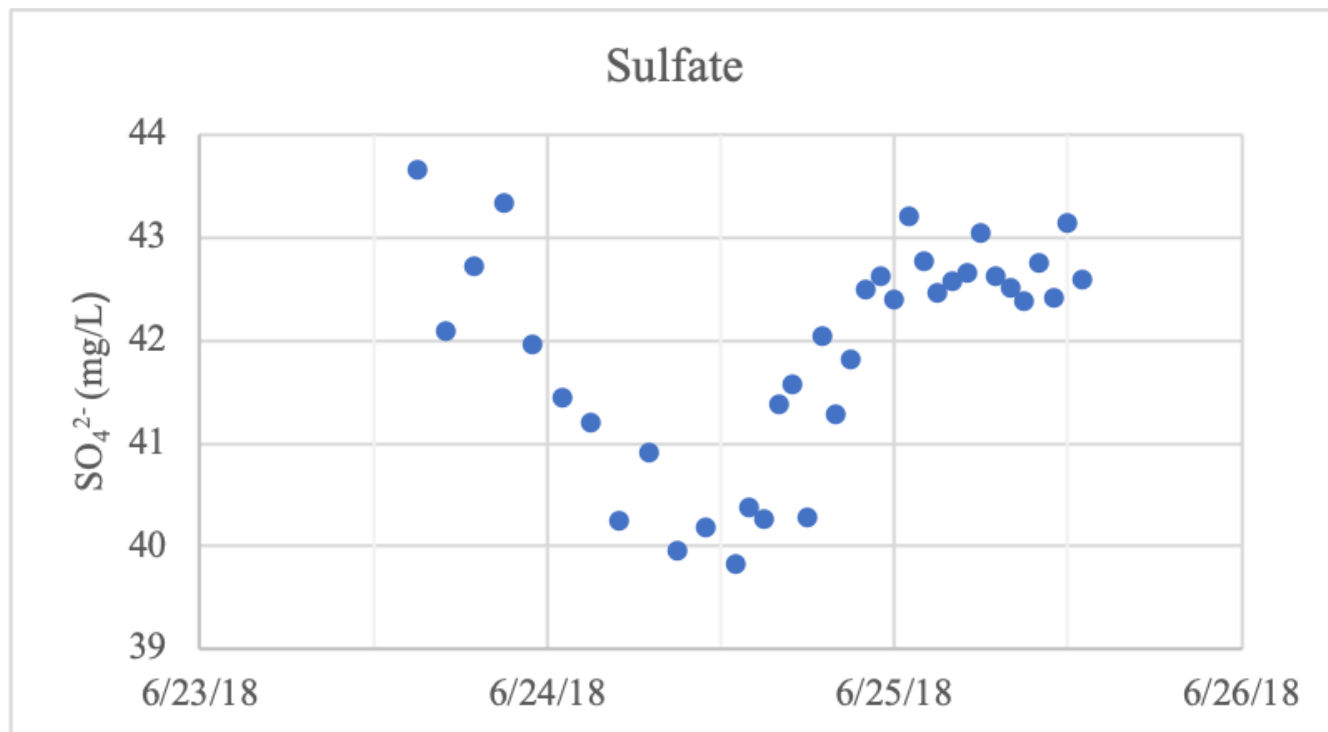

Figure 41: Plot showing sulfate concentration during time series sampling. 


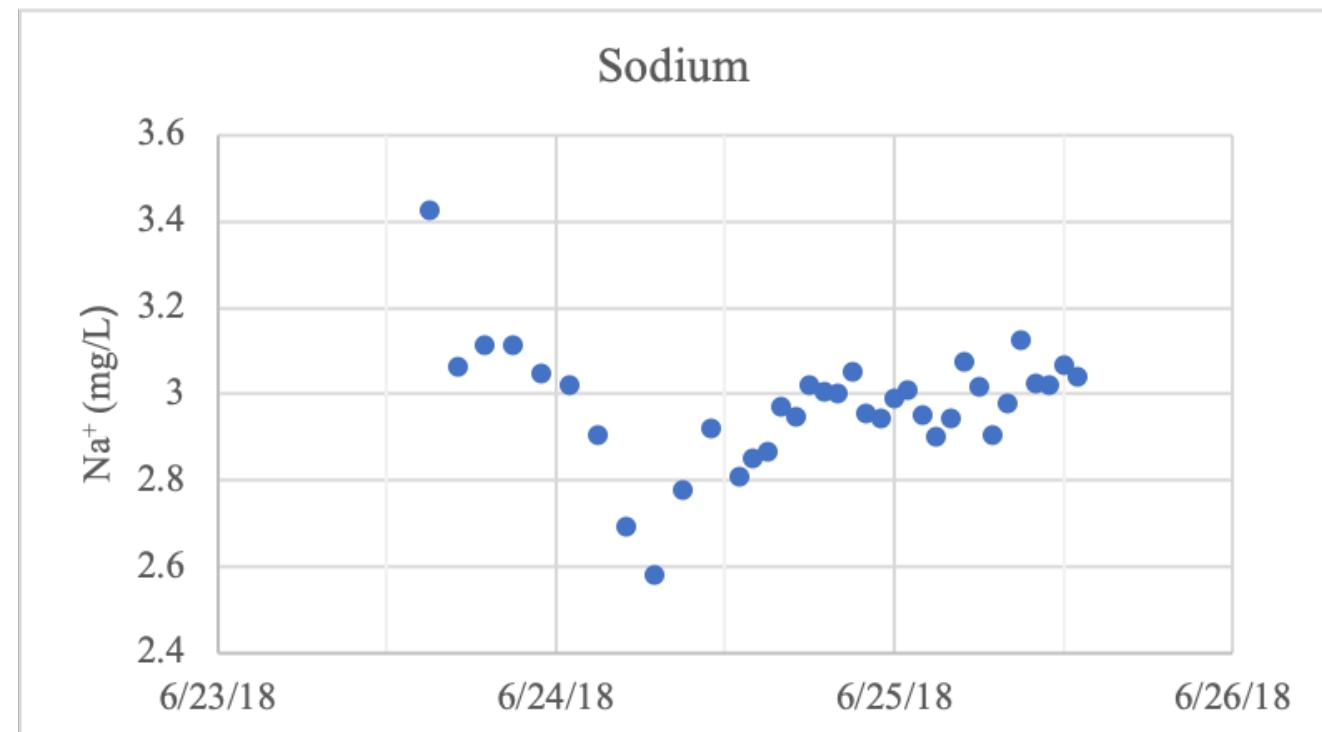

Figure 42: Plot showing sodium concentration during time series sampling.

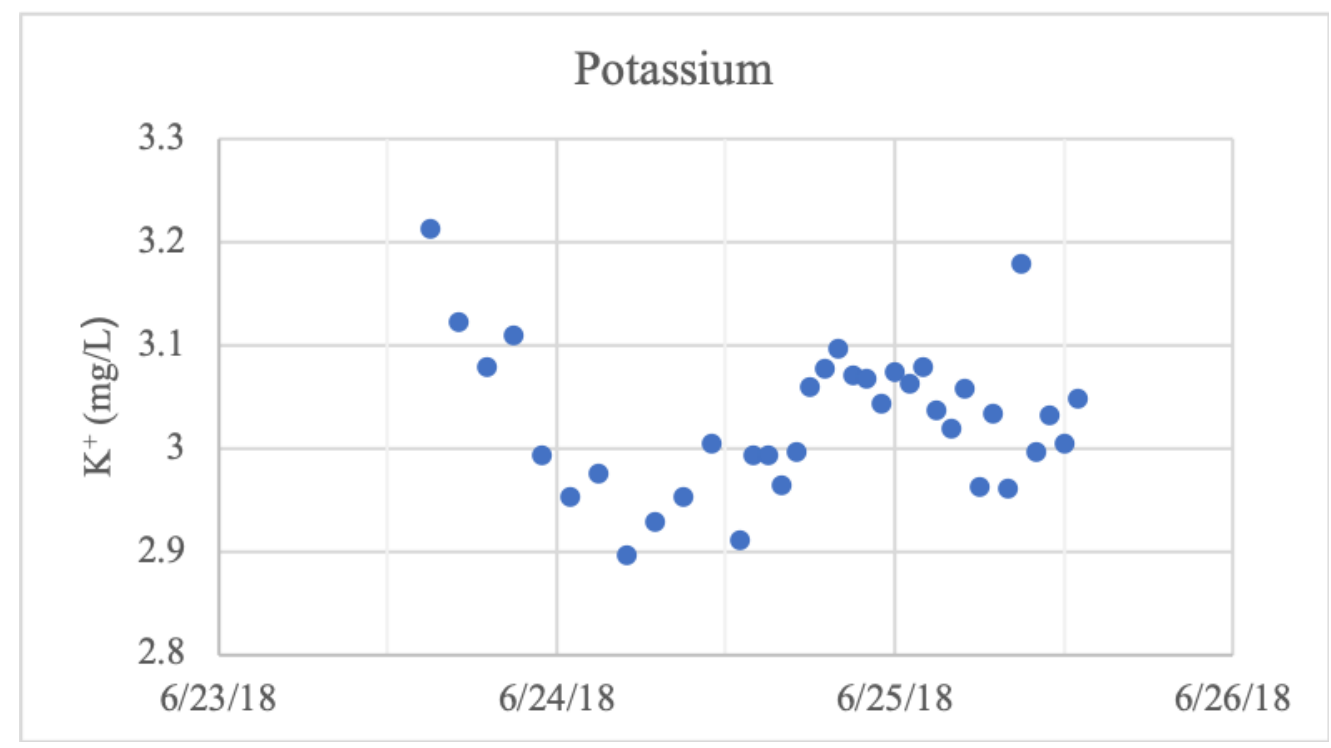

Figure 43: Plot showing potassium concentration during time series sampling. 


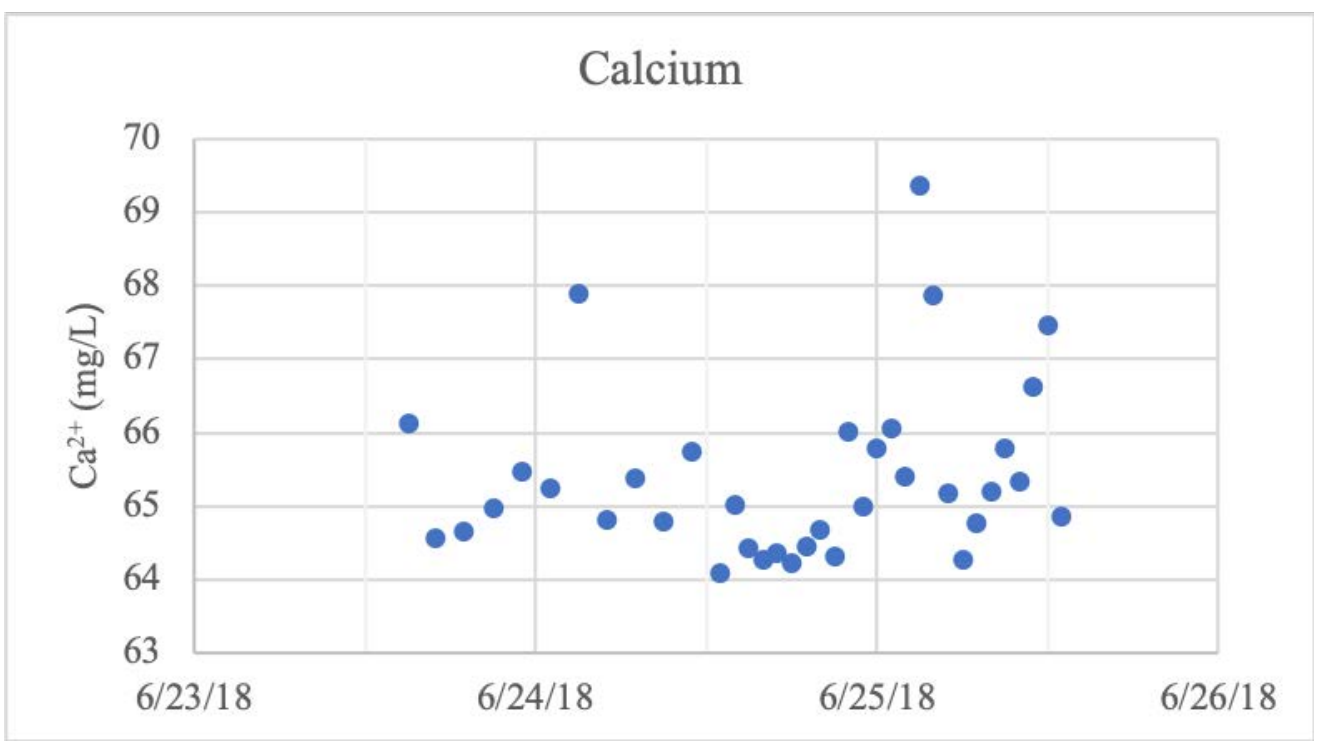

Figure 44: Plot showing calcium concentration during time series sampling.

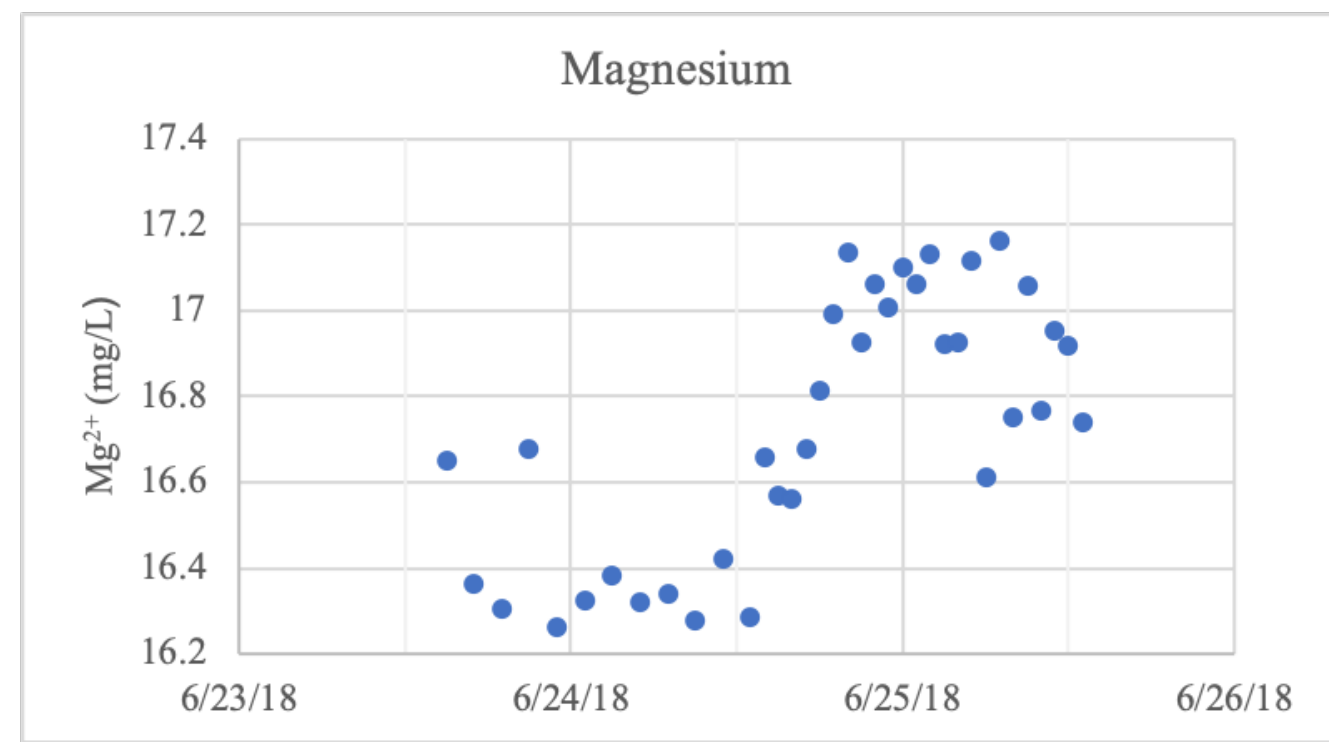

Figure 45: Plot showing magnesium concentration during time series sampling. 


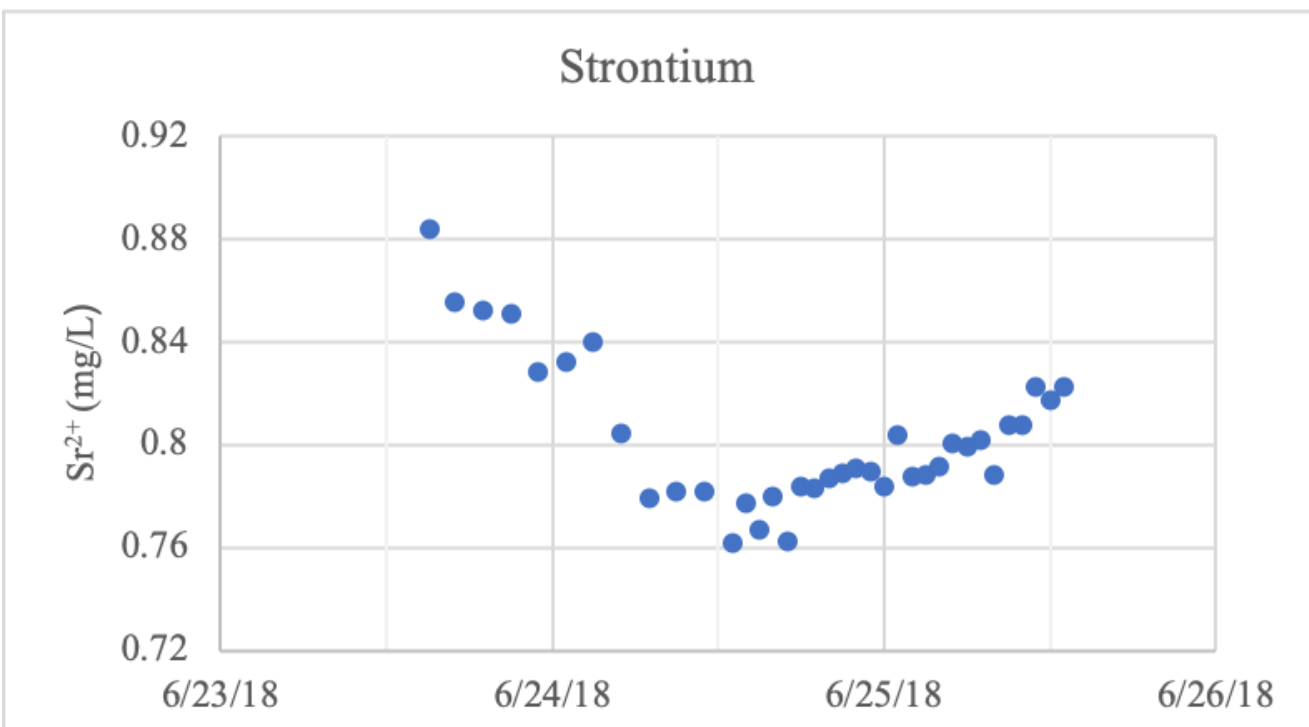

Figure 46: Plot showing strontium concentration during time series sampling.

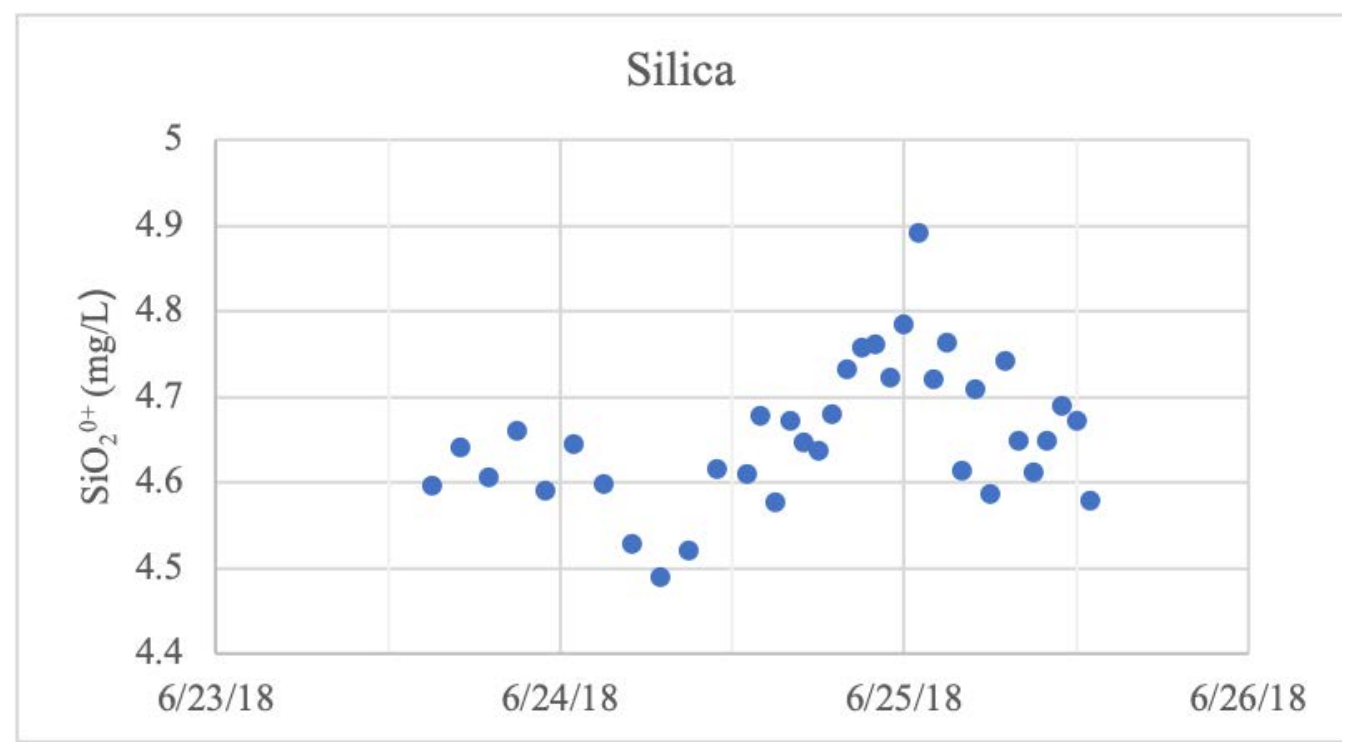

Figure 47: Plot showing silica concentration during time series sampling. 


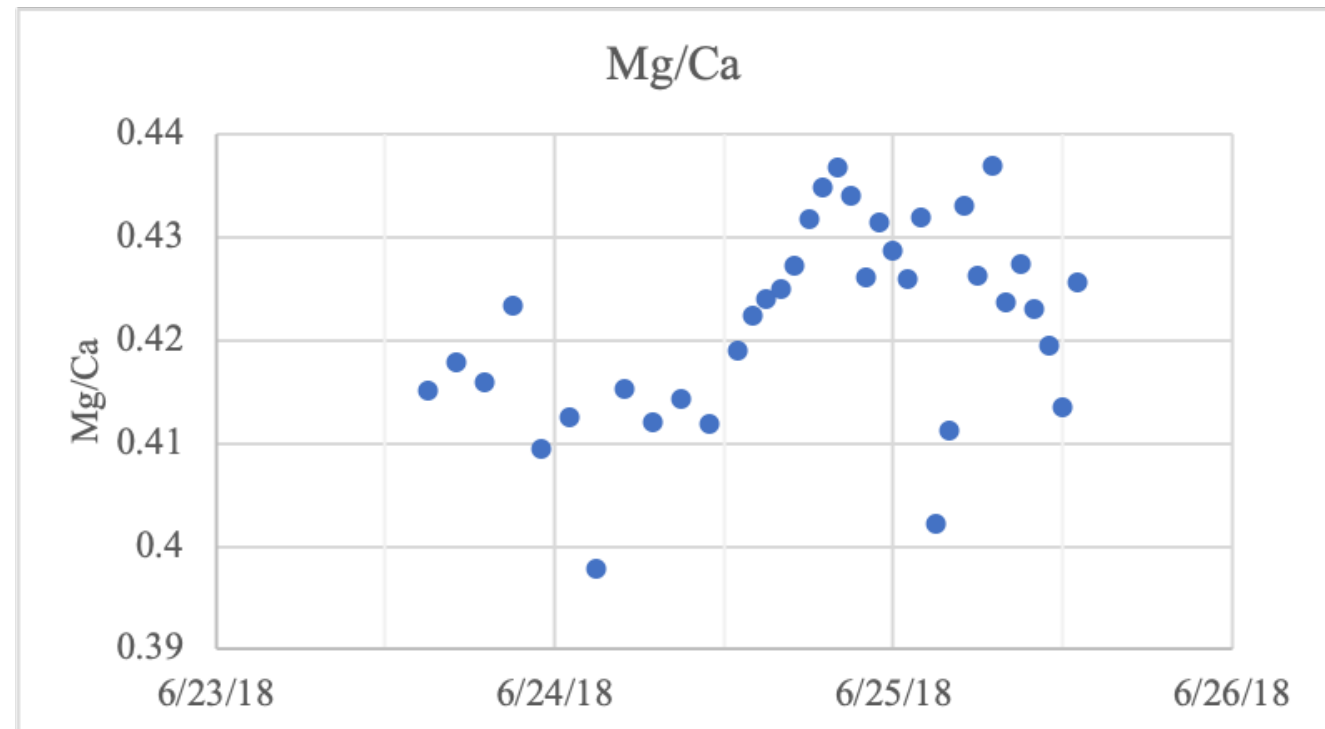

Figure 48: Plot showing magnesium/calcium ratio during time series sampling.

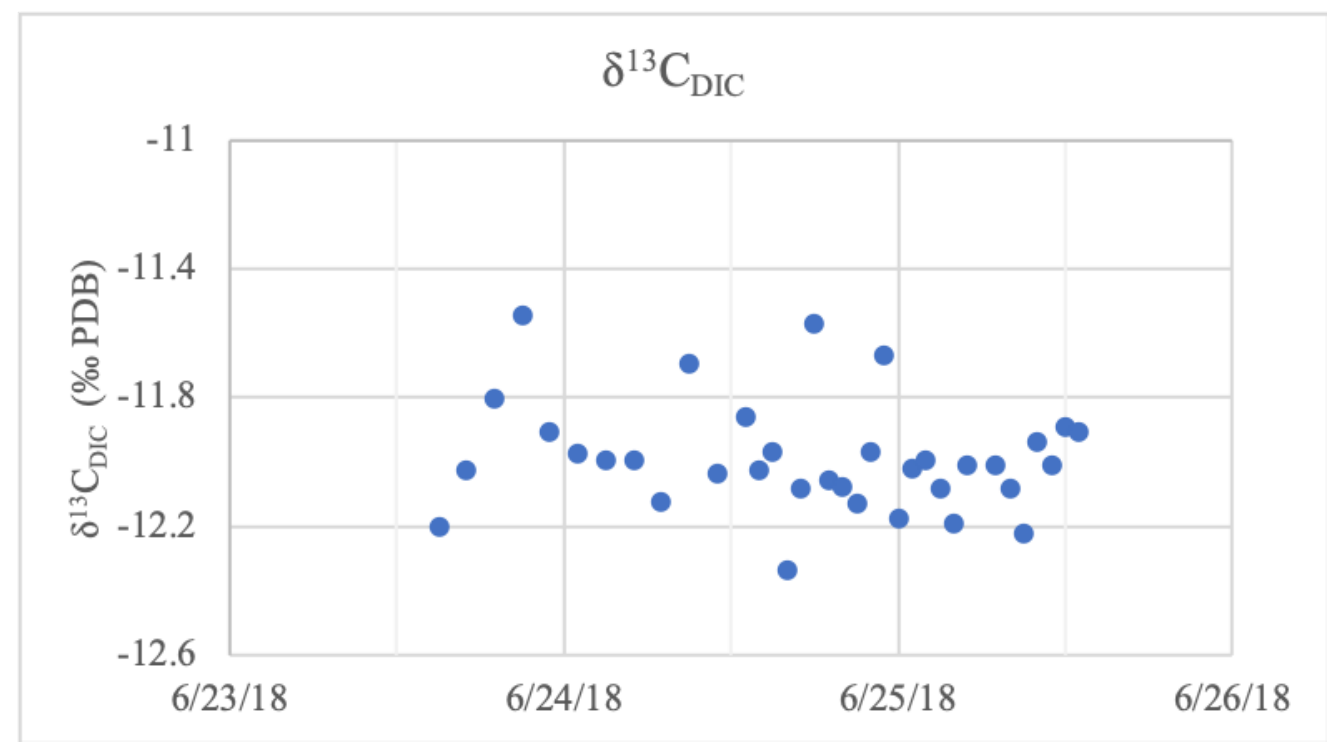

Figure 49: Plot showing $\delta^{13}$ CDIC values during time series sampling. 


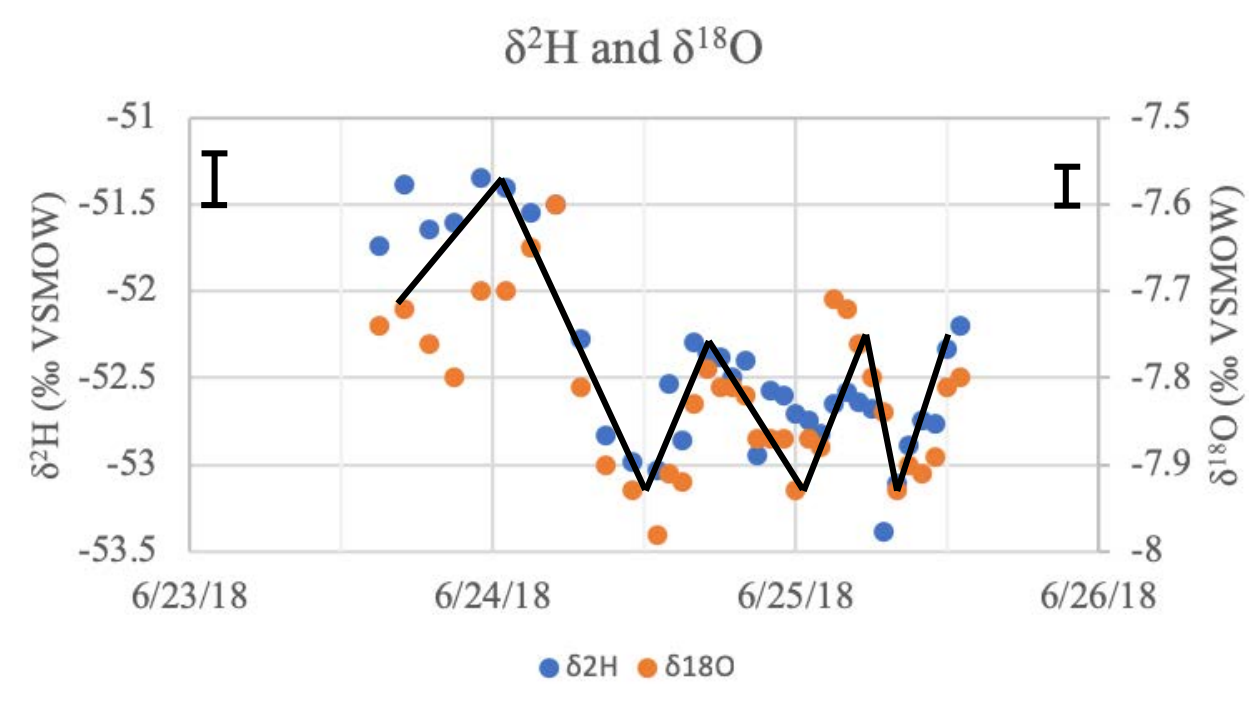

Figure 50: Plot showing $\delta^{2} \mathrm{H}$ and $\delta^{18} \mathrm{O}$ values during time series sampling. Line shows the general trend in the data. Error bar for $\delta^{2} \mathrm{H}=0.3 \%$. Error bar for $\delta^{18} \mathrm{O}=0.05 \%$. 


\subsection{Dye Tracing}

\subsubsection{Summer Baseflow Trace}

On June 18, $1 \mathrm{~d}$ after the baseflow dye injection at Xiao Shanba (location \#98), dye was visible in water discharging from all three of the observed outlets at Laoheitan (location \#109). Dye was still visible on June 19 at Laoheitan and was visible at Daxing (location \#121) on June 20, but dye was not visually observed at Sanjianfang (location \#123) or Liugu (location \#129). Except at Maoshuikeng, none of the background bugs produced any positive dye spectra and there was no observable fluorescence from the cotton cloth (Figure 51). The peak for fluorescein recorded by the Maoshuikeng background bug was significantly lower than the peak observed from the bug that was deployed to capture the baseflow dye trace. Analyses of the charcoal bugs showed dye presence at Sanjianfang, Liugu, A Jiu Zhai, and Maoshuikeng (location \#294) (Figure 52). The bug deployed at Maokeng was vandalized at an unknown time between deployment and retrieval, so even though enough charcoal was recovered to test for dye, its absence does not conclusively indicate that no dye passed through Maokeng. The bugs at Aliangzhai (location \#117) and Tian Guan (location \#132) were lost during recovery and therefore could not be tested. 


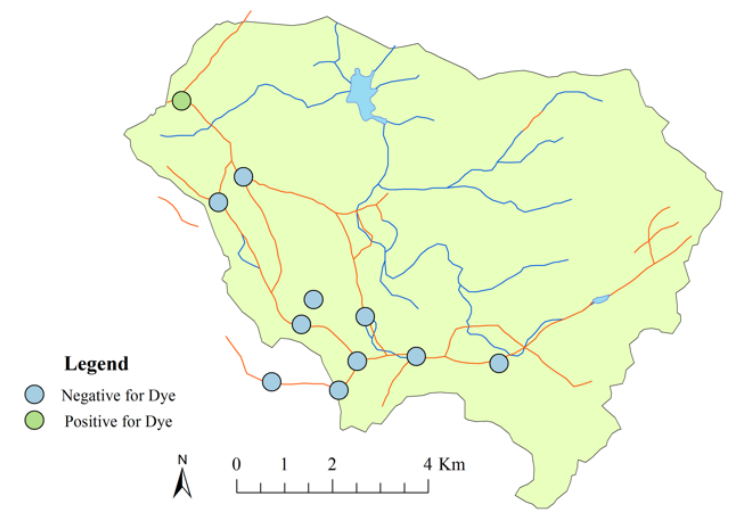

Figure 51: Map showing summer background bug results before dye injections.

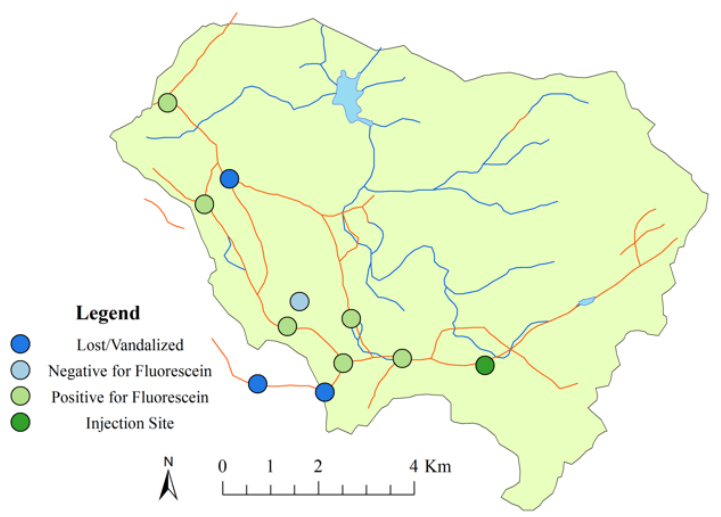

Figure 52: Map showing summer baseflow trace bug results.

Continuous loggers at Laoheitan measured a water-level peak $\sim 40$ min prior to the salt water and dye injection (Figure 53B). The water level began to fall when the saltwater and dye injection occurred, at which time water level increased again for $\sim 2.5 \mathrm{~h}$ before decreasing. Approximately $21 \mathrm{~h}$ after the water level peak, a broad EC peak was superimposed on an increasing trend (Figure 53A). 

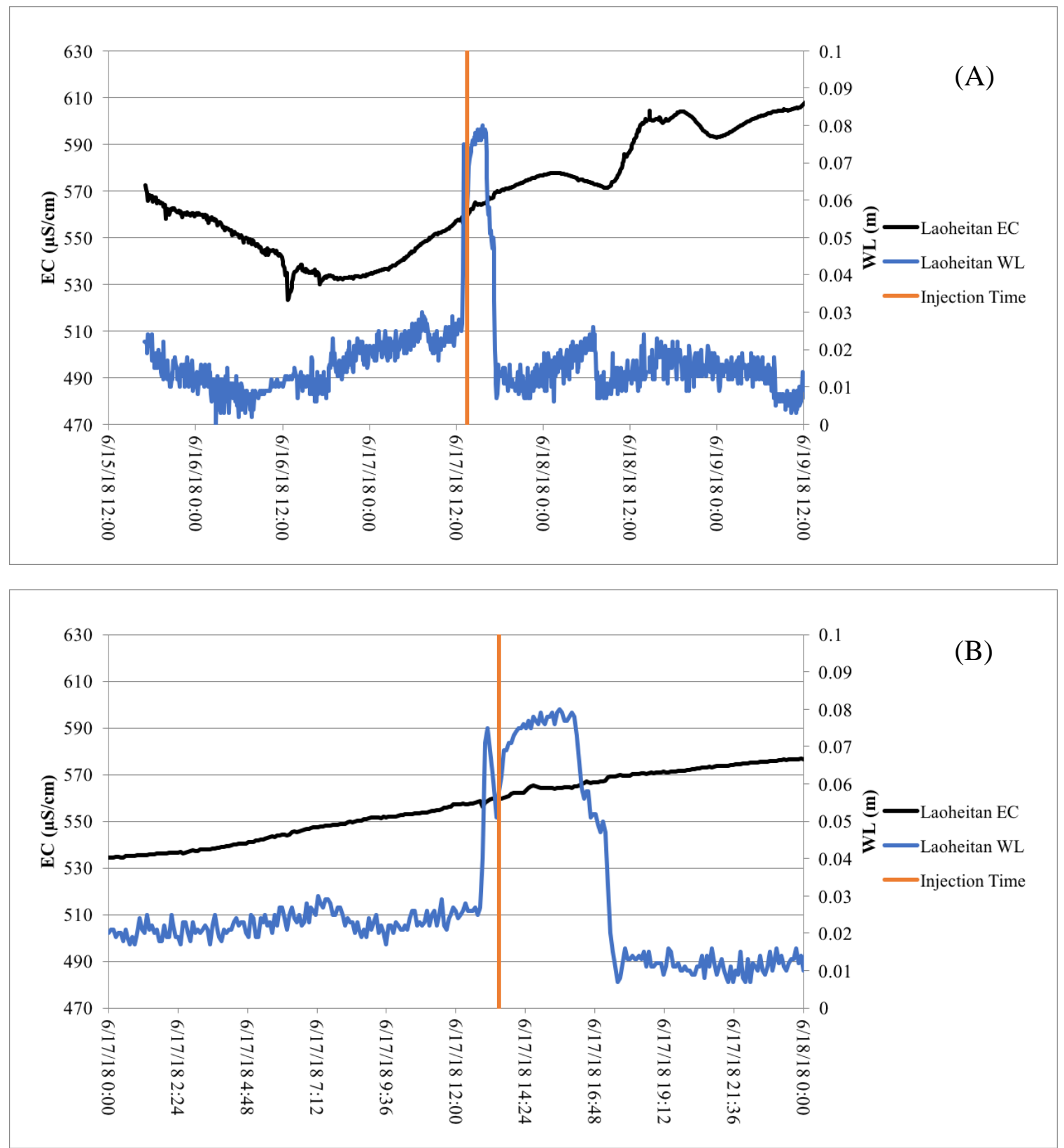

Figure 53: Plot showing water level (blue) and EC (black) at Laoheitan with the Xiao Shanba injection time marked (vertical orange line). 


\subsubsection{Summer Stormflow Trace}

No dye was detected in the Maoshuikeng (location \#294) water samples and no dye was recovered from the glass sample vials. However, all the charcoal bugs that were redeployed before the summer stormflow trace indicated the presence of dye (Figure 54). The bug that was redeployed at Aliangzhai (location \#117) was positive for eosine, the bugs at Liugu (location \#129) and Maoshuikeng (location \#294) were positive for both fluorescein and eosine. Additionally, the bug that was deployed at A Jiu Zhai while it was dry, before the baseflow trace, produced a positive result for fluorescein and eosine.

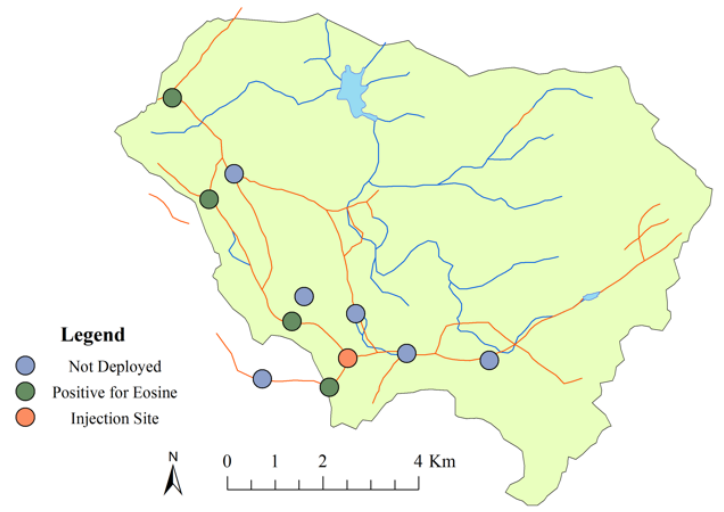

Figure 54: Map showing summer stormflow trace bug results. 
Table 2: Summer bug results summary.

\begin{tabular}{|l|l|l|l|}
\hline \multicolumn{1}{|c|}{ Location } & Background & \multicolumn{1}{|c|}{ Baseflow Trace } & \multicolumn{1}{|c|}{ Stormflow Trace } \\
\hline $\begin{array}{l}\text { Xiao Shanba } \\
\text { location \#98) }\end{array}$ & Negative & Positive for fluorescein & Not deployed \\
\hline $\begin{array}{l}\text { Laoheitan } \\
\text { location \#109) }\end{array}$ & Negative & Positive for fluorescein & Not deployed \\
\hline $\begin{array}{l}\text { Laoheitan } \\
\text { Duplicate }\end{array}$ & Negative & Positive for fluorescein & Not deployed \\
\hline $\begin{array}{l}\text { Daxing } \\
\text { (location \#121) }\end{array}$ & Negative & Positive for fluorescein & Not deployed \\
\hline $\begin{array}{l}\text { Aliangzhai } \\
\text { (location \#117) }\end{array}$ & Negative & Lost & Positive for eosine \\
\hline $\begin{array}{l}\text { Tian Guan } \\
\text { (location \#132) }\end{array}$ & Negative & Lost & Not deployed \\
\hline $\begin{array}{l}\text { Sanjianfang } \\
\text { (location \#123) }\end{array}$ & Negative & Positive for fluorescein & Not deployed \\
\hline $\begin{array}{l}\text { Trash Spring } \\
\text { (location \#127) }\end{array}$ & Negative & Negative & Not deployed \\
\hline $\begin{array}{l}\text { Liugu } \\
\text { (location \#129) }\end{array}$ & Negative & Positive for fluorescein & $\begin{array}{l}\text { Positive for } \\
\text { fluorescein and eosine }\end{array}$ \\
\hline A Jiu Zhai & Negative & Positive for fluorescein and eosine \\
\hline $\begin{array}{l}\text { Maokeng } \\
\text { (location \#302) }\end{array}$ & Negative & Vandalized & Not deployed \\
\hline $\begin{array}{l}\text { Maoshuikeng } \\
\text { location \#294) }\end{array}$ & $\begin{array}{l}\text { Positive for } \\
\text { fluorescein }\end{array}$ & Positive for fluorescein & $\begin{array}{l}\text { Positive for } \\
\text { fluorescein and eosine }\end{array}$ \\
\hline Field Blanks & Negative & Negative & \multicolumn{2}{|c|}{} \\
\hline
\end{tabular}




\subsubsection{Winter Baseflow Traces}

Before any of the winter dye injections, fluorescein still appeared to be visible at Xiao Shanba when winter synoptic samples were taken (nearly 4 months after injection) (Figure 55). This result, which is consistent with elevated $\mathrm{Na}^{+}$and $\mathrm{Cl}^{-}$values measured at the same time, could reflect slow leaching of co-injected dye and salt from soil around the sink. No dye was visible at Laoheitan. Because winter injections occurred downgradient at Sanjianfang and Daxing, no bugs were deployed and no water samples were taken to confirm the presence or absence of dye at Xiao Shanba or Laoheitan. One day after the injections, which occurred on December 5, dye was still visible but much less concentrated at both Sanjianfang and Daxing. Three days after the injections, residual dye adsorbed to the soil and sediment substrate was observed at each injection site, but no dye was visible in the water. No pumping was observed at Daxing, Sanjianfang, or Aliangzhai, but pumping was observed during each visit to Tian Guan (location \#132) during the daily bug swaps. Because the rice paddies were dormant during this time, the water was likely being used for other purposes, such as domestic use or construction. Liugu was the only downgradient location where dye was visibly present in the water after injection. The first visible arrival occurred $3 \mathrm{~d}$ after dye injection and became stronger the next day and weaker the day after (Figure 56). Based on this visual change in color, the main dye pulse arrived at Liugu $4 \mathrm{~d}$ after injection.

All of the background bugs deployed tested negative for dye. One day after the injections, the bug deployed at Aliangzhai recorded the arrival of sulforhodamine $\mathrm{B}$, the dye used at Daxing (Figure 57). The following day, sulforhodamine B was detected in bugs from Aliangzhai and Tian Guan (Figure 58). Four days after injection, bugs 
confirmed the presence of dye at Liugu as well (Figure 59). Interestingly, even though dye was visibly observed at Liugu on December 8, the bug that was swapped just after arrival did not show signs of dye. Bugs were deployed at Sanjianfang and Daxing in an attempt to capture hypothesized flow between the two injection sites between December 8 and 10, but dye cross-over was not observed. In order to extend the monitoring time as long as possible, bugs were deployed at Maokeng and Maoshuikeng on the $10^{\text {th }}$ and retrieved on the $13^{\text {th }}$. Sulforhodamine B was positively identified from the Maoshuikeng bug, but no dye was observed at Maokeng at any point during the winter (Figure 60). Based on the bug results for sulforhodamine B, and assuming straight-line flow paths, velocities from Daxing to several other karst features can be estimated:

- Daxing to Aliangzhai: $>0.75$ km/d

- Daxing to Tian Guan: 1-2 km/d

- Daxing to Liugu: 0.4-0.5 km/d (1.5 km in 3-4 d)

- Daxing to Maoshuikeng: 0.9-1.5 km/d (7.4 km in 5-8 d). 


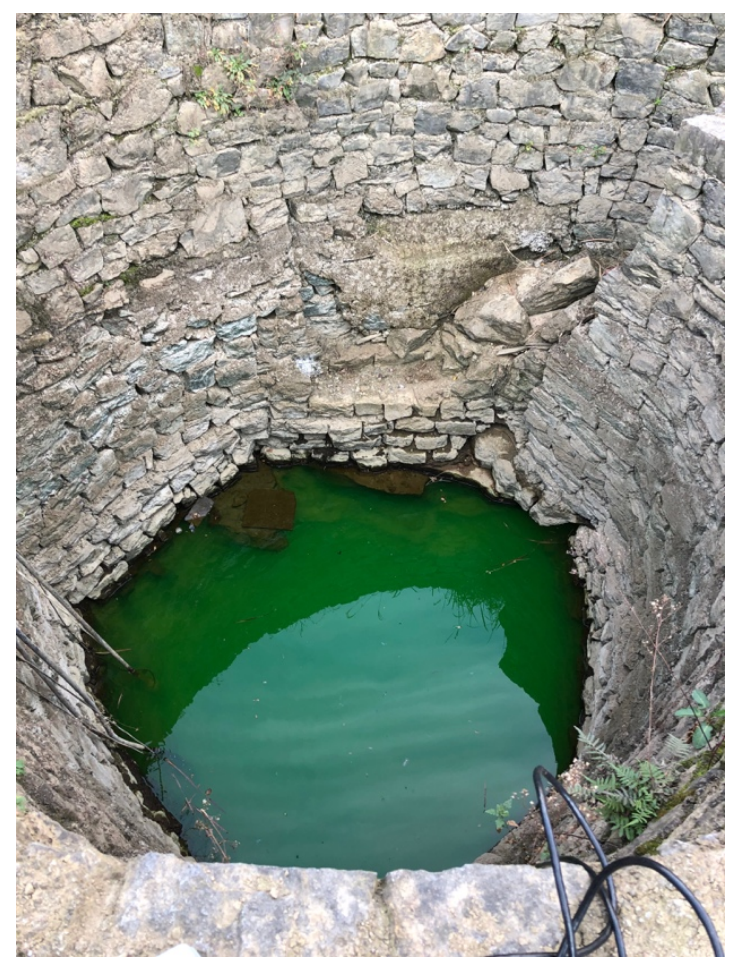

Figure 55: Field photograph of Xiao Shanba on December 3. Note the green color suggestive of residual fluorescein.
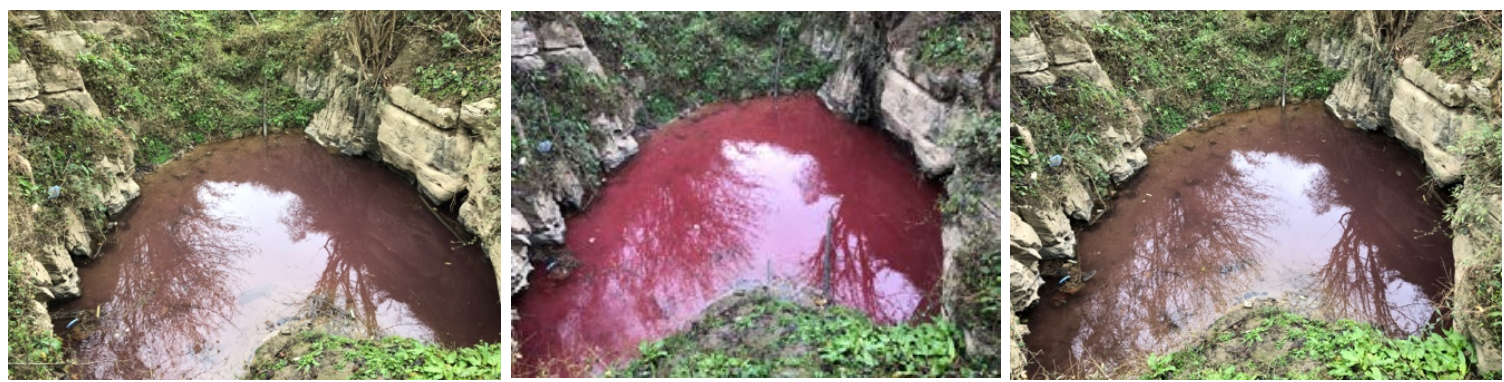

Figure 56: Field photographs of Liugu showing the progression of dye arrival. From left to right, these images were taken on December 8, 9, and 10. 


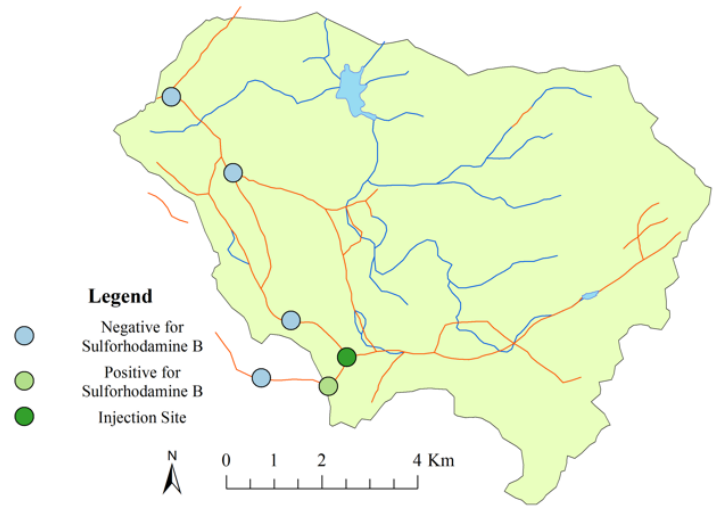

Figure 57: Map showing results of winter bugs retrieved $1 \mathrm{~d}$ after injections.

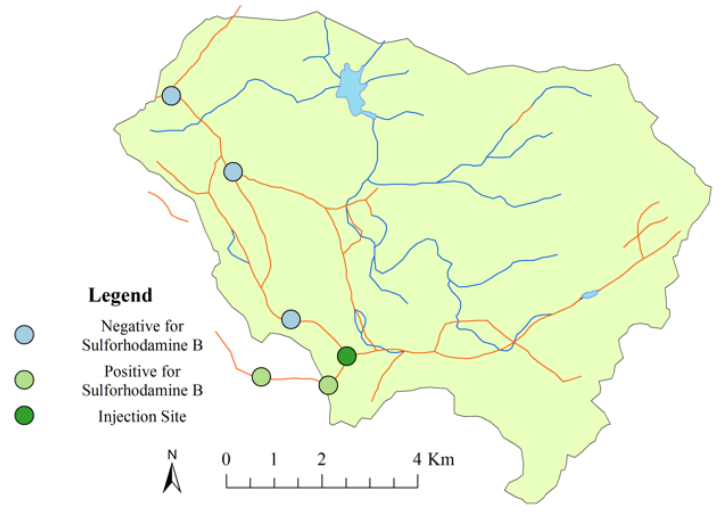

Figure 58: Map showing results of winter bugs retrieved 2 and $3 \mathrm{~d}$ after injections.

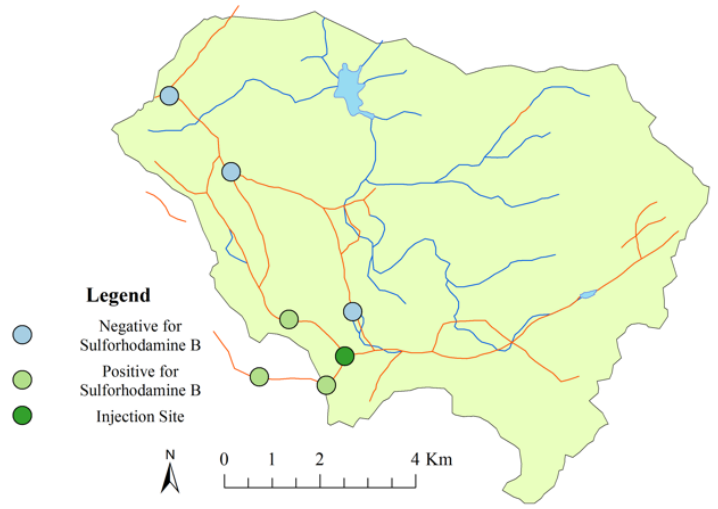

Figure 59: Map showing results of winter bugs retrieved 4, 5, and $6 \mathrm{~d}$ after injections. 


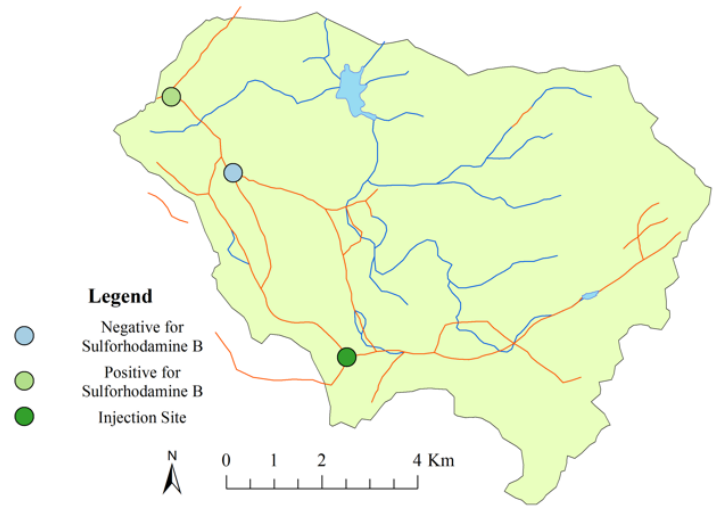

Figure 60: Map showing results of winter bugs retrieved $8 \mathrm{~d}$ after injections.

Table 3: Winter bug results summary.

$+=$ Positive for sulforhodamine $\mathrm{B}$

- = Negative for dye

\begin{tabular}{|l|c|c|c|c|c|}
\hline \multicolumn{1}{|c|}{ Location } & Background & Day 1 & Days 2-3 & Days 4-6 & Day 8 \\
\hline Sanjianfang & - & N/A & N/A & - & N/A \\
\hline Daxing & - & N/A & N/A & - & N/A \\
\hline Aliangzhai & - & + & + & + & N/A \\
\hline Liugu & - & - & - & + & N/A \\
\hline Tian Guan & - & - & + & + & N/A \\
\hline Maokeng & - & - & - & - & - \\
\hline $\begin{array}{l}\text { Maokeng } \\
\text { (2-day bug) }\end{array}$ & N/A & - & - & - & N/A \\
\hline $\begin{array}{l}\text { Maoshuikeng } \\
\text { Maoshuikeng } \\
\text { (2-day bug) }\end{array}$ & N/A & - & - & - & N/A \\
\hline Field Blanks & & & & & - \\
\hline
\end{tabular}




\section{CHAPTER 4. DISCUSSION}

\subsection{Controls on Solute and Isotope Chemistry}

\subsubsection{Synoptic Sampling Data}

EC, carbonate alkalinity, and to some degree, $\mathrm{pH}$, can be seen as analogues for water residence time (Figures 16, 19, and 18). These parameters increase along flowpaths through the catchment and are generally higher during the winter. This is likely because, during the dry season, less water is flowing within the conduit system, meaning that hydraulic heads and groundwater velocities are lower.

Residence time and lithology seem to be the two main controls on $\mathrm{Mg} / \mathrm{Ca}$ ratios. Longer residence times, either as a result of slower water velocity or longer flowpaths, correspond with higher $\mathrm{Mg} / \mathrm{Ca}$ ratios. This is part of the reason why $\mathrm{Mg} / \mathrm{Ca}$ ratios are higher in the winter and towards the outlet (Figure 20). Additionally, Maokeng (location \#302) and Maoshuikeng (location \#294) are located within the uppermost layer $\left(\mathrm{T}_{2} \mathrm{~g}^{3}\right)$ of the Guanling Formation, which is composed chiefly of dolomite (Figure 4). This lithology change likely accounts for some of the change in water chemistry. Similarly, higher $\mathrm{SO}_{4}$ concentrations during the winter may reflect a greater contribution of deep groundwater that has dissolved gypsum along its flowpath.

Trash Spring seems to be an outlier compared to the other karst features. It was the only karst feature for which no dye was observed during the summer baseflow trace (Table 2). Additionally, water parameter measurements such as EC, alkalinity, and $\mathrm{Mg} / \mathrm{Ca}$ ratios were all notably lower than other springs (Figures 16, 19, and 20). Water temperature was close to the diurnal range of temperatures logged at Daxing. Overall, 
this suggests that flowpath lengths at Trash Spring are relatively short and that it is perched above the main conduit network.

Comparing $\delta^{13} C_{\text {DIC }}$ data from the synoptic samples shows a general decrease in $\delta^{13} C_{\text {DIC }}$ from the summer monsoon season to the winter dry season (Figure 21). A twotailed t-test was performed in order to determine if the difference between the summer and winter $\delta^{13} C_{\text {DIC }}$ values is significant. The results indicate that the summer and winter values are statistically different $(\mathrm{p}<0.01)$. The $\delta^{13}$ CDIC values during the summer are roughly midway between $\mathrm{C}_{3}$ plant $\delta^{13} \mathrm{C}$ values (-28\%o) and rock $\delta^{13} \mathrm{C}$ values (0\%), and close to $\mathrm{C}_{4}$ plant $\delta^{13} \mathrm{C}$ values (-14\%o) (O’Leary, 1988). The winter synoptic samples shift closer towards the rock $\delta^{13} \mathrm{C}$ end of the spectrum. This is consistent with longer residence times, meaning more dissolution, and less oxidation of organic material during the winter. While the main crop within the catchment is rice (a $\mathrm{C}_{3}$ plant), corn (a $\mathrm{C}_{4}$ plant) is also grown. Additionally, oxidation of other plant matter also likely influences $\delta^{13} \mathrm{C}$ values. One notable outlier in the data is Maokeng, which has a more enriched $\delta^{13}$ CDIC value than the other locations, both in the winter and the summer. The dissolution of more dolomite around Maokeng could explain this anomalous $\delta^{13} \mathrm{C}$ value. Sheppard and Schwarcz (1970) found that dolomite $\delta^{13} \mathrm{C}$ values are $~ 1 \%$ higher than co-occurring low-magnesium calcite. Given that alkalinity values at Maokeng are not particularly high, isotopic variation, rather than the total amount of dissolution, is likely the cause of this enrichment (Figure 19).

When plotting $\delta^{2} \mathrm{H}$ vs. $\delta^{18} \mathrm{O}$, water samples generally fell near the GMWL, with summer samples more enriched than winter samples (Figure 26). The most depleted sample, from Xiao Shanba during the summer, appears to have been mostly rainwater, 
even though it had not rained for $5 \mathrm{~d}$ before the sample was taken. The inference of groundwater dilution by rainwater is supported by the relatively low alkalinity and $\mathrm{Cl}^{-}$of the sample. The two most enriched samples, from Trash Spring (location \#127) and Daxing (location \#121) at the time of injection, both fall below the GMWL, which suggests evaporation (Fritz et al., 1976; Lakey and Krothe, 1996). The synoptic sample from Sanjianfang during the winter also fits this trend. One possible explanation for the anomalously enriched sample at Daxing is that the previous storm caused evaporated paddy water to overflow into the pool. This is consistent with observations of water flowing down the steps as dye was injected. The summer synoptic sample from Maoshuikeng plots within the field of time series storm samples from that spring and is more depleted than other summer synoptic samples (apart from Xian Shanba). This is consistent with Maoshuikeng discharging a substantial component of deeper groundwater recharged at higher elevation within the basin. The outlier among the winter isotope data (Sanjianfang) may not be as connected to the rest of the conduit network as it was during the summer, perhaps because the northern branch of the conduit network is shallower. It also seems to have experienced some evaporation. This could explain why the eosine injected at Sanjianfang (location \#123) was not observed at any other karst feature. Yue et al. (2018) found that water isotope values deviate from the GMWL during the winter as a result of drier conditions. Measured winter synoptic samples also seem to deviate slightly from this line. Synoptic samples were generally more enriched than the samples of Zhang et al. (2019) from the higher-elevation Chenqi sub-catchment. 


\subsubsection{Time Series Analysis}

The arrival of stormflow at Maoshuikeng was indicated by minimum values of EC, $\mathrm{T}, \mathrm{pH}$, and various solutes $\left(\mathrm{Cl}, \mathrm{SO}_{4}, \mathrm{Na}, \mathrm{K}, \mathrm{Mg}, \mathrm{Sr}, \mathrm{Si}\right) \sim 24 \mathrm{~h}$ after the stage peak. The fact that the secondary maxima and minima follow the initial minima for EC, $\mathrm{T}$, and $\mathrm{pH}$ suggests the arrival of a second storm pulse. The broad decline in $\mathrm{NO}_{3}$ during the recession suggests a gradual flushing of fertilizer that is liberally applied to rice paddies throughout the catchment (Figure 40). The increasing $\mathrm{Mg} / \mathrm{Ca}$ ratio, spurred by the increasing Mg concentration, suggests that older water follows the arrival of stormflow (Figure 48).

More distinctly than solutes and field parameters, the $\delta^{2} \mathrm{H}$ and $\delta^{18} \mathrm{O}$ time series plots for Maoshuikeng appear to show three pulses of recharge, as indicated by successive drops and rebounds. They may represent recharge from progressively farther up the watershed, particularly since $\delta^{2} \mathrm{H}$ is most depleted for the third pulse, consistent with higher-elevation recharge. This is supported when comparing the $\delta^{2} \mathrm{H}$ values measured by Chen et al. (2018) within the Chenqi sub-catchment, which clustered around -60\%, markedly more depleted than the values measured at Maoshuikeng (Figure 28). The three pulses observed at Maoshuikeng could alternatively represent contributions from different branches of the conduit network. The best way to test this hypothesis would be to conduct a tracer test along each branch during a summer storm event. 


\subsubsection{Saturation Index Calculations}

Based on PHREEQC calculations, the synoptic water samples seemed to be closer to saturation with respect to calcite during the winter, especially in the southwestern-most part of the catchment (Figure 61). This was likely a result of less dilution and slower flow, allowing the water to approach equilibrium with the matrix. Water samples were further from saturation with respect to dolomite, with the exception of the summer Maokeng sample (Figure 62). In fact, this sample had higher SI values with respect to all three carbonate minerals, likely the result of a relatively high $\mathrm{pH}$ measurement (8.10). Like calcite, $\mathrm{SI}_{\text {strontianite }}$ winter values were somewhat closer to saturation than summer values (Figure 63). All water samples were undersaturated with respect to gypsum and celestite (Figures 64 and 65). Both indices were generally more negative during the summer, except at Maokeng and Maoshuikeng. Higher sulfate concentrations, as a result of slower flow especially in the upper catchment, account for higher gypsum and celestite saturation indices during the winter.

Table 4: Ranges of calculated summer and winter synoptic sample saturation indices.

\begin{tabular}{|l|l|l|}
\hline \multicolumn{1}{|c|}{ Saturation Index } & \multicolumn{1}{|c|}{ Summer } & \multicolumn{1}{c|}{ Winter } \\
\hline SIcalcite & $-0.528-0.780$ & $-0.377-0.108$ \\
\hline SI $I_{\text {dolomite }}$ & $-1.622-1.238$ & $-1.146--0.144$ \\
\hline SI $_{\text {strontianite }}$ & $-1.852--0.458$ & $-1.952--0.847$ \\
\hline SI $_{\text {gypsum }}$ & $-1.877--1.462$ & $-2.178--1.190$ \\
\hline SI $_{\text {celestite }}$ & $-2.029--1.369$ & $-2.841--0.988$ \\
\hline
\end{tabular}



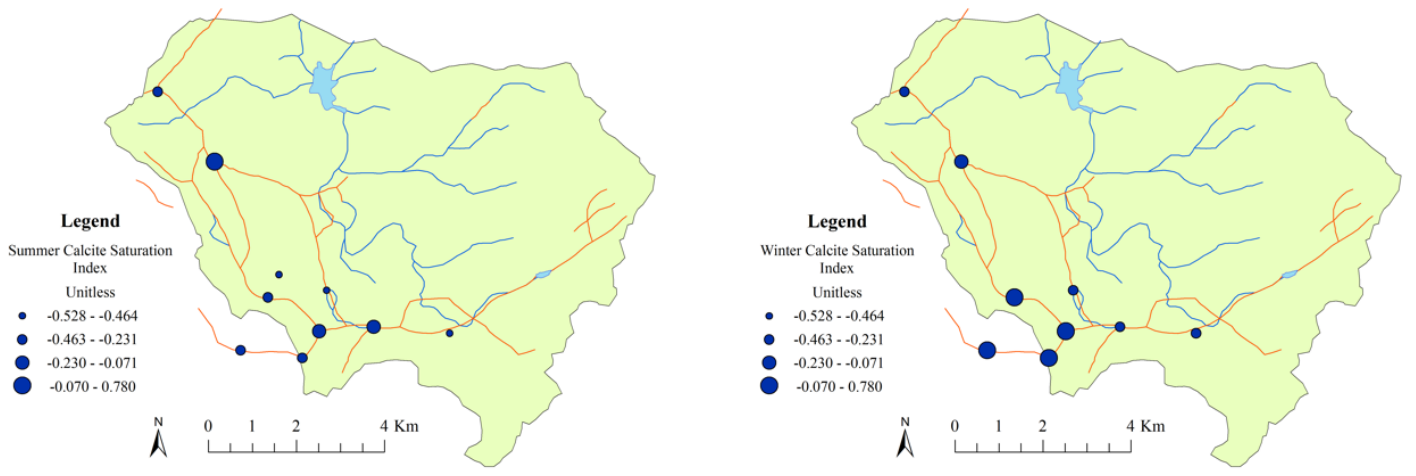

Figure 61: Maps comparing synoptic water sample saturation index with respect to calcite. Larger point diameter corresponds to a value that is closer to saturation. Summer samples are on the left, winter samples are on the right.
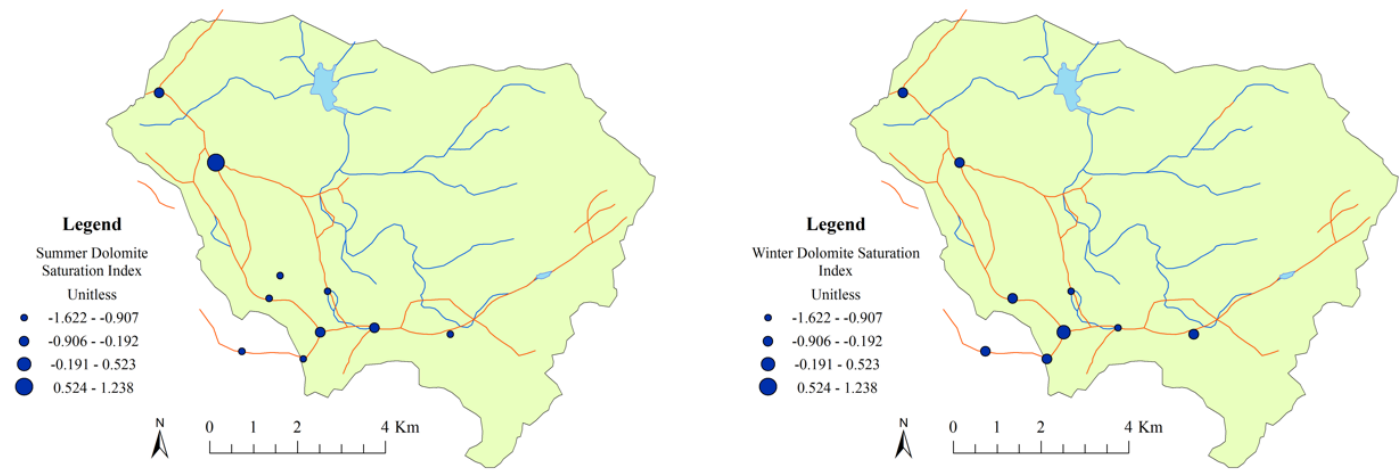

Figure 62: Maps comparing synoptic water sample saturation index with respect to dolomite. Larger point diameter corresponds to a value that is closer to saturation or more supersaturated. Summer samples are on the left, winter samples are on the right. 

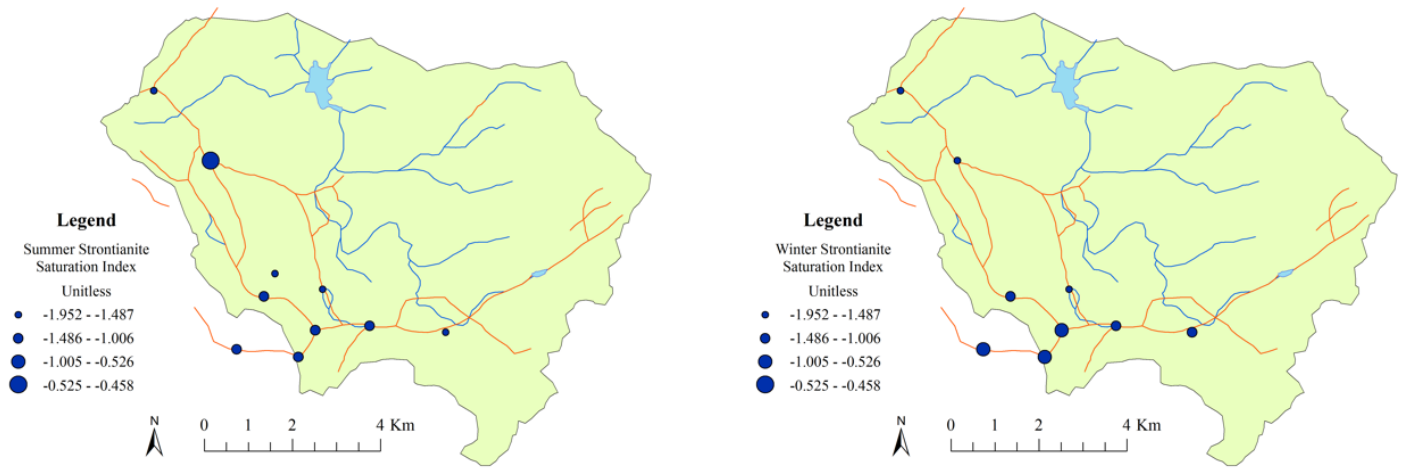

Figure 63: Maps comparing synoptic water sample saturation index with respect to strontianite. Larger point diameter corresponds to a value that is closer to saturation. Summer samples are on the left, winter samples are on the right.
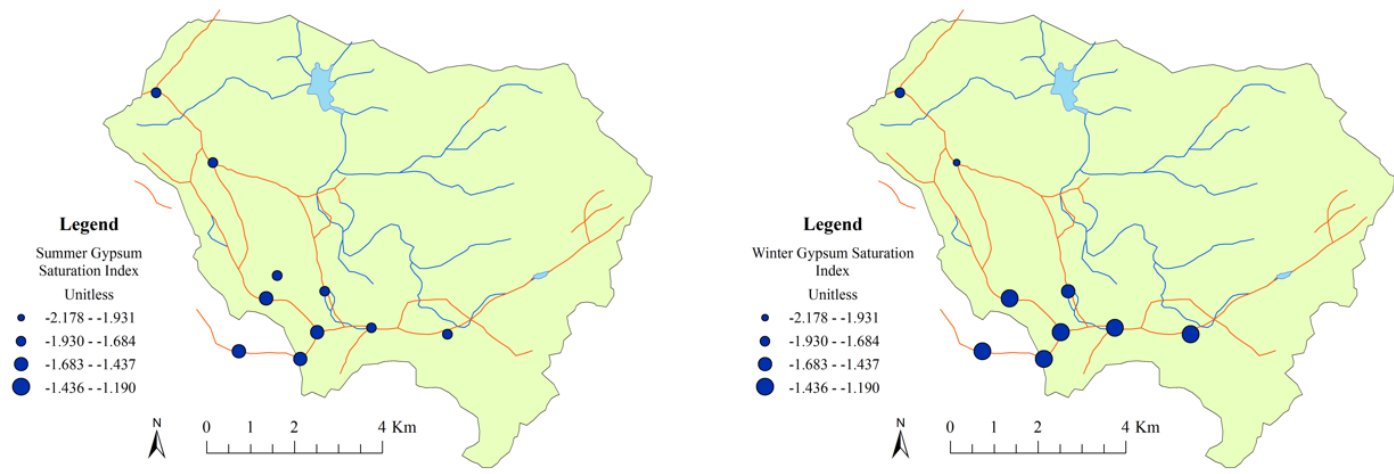

Figure 64: Maps comparing synoptic water sample saturation index with respect to gypsum. Larger point diameter corresponds to a value that is closer to saturation. Summer samples are on the left, winter samples are on the right. 

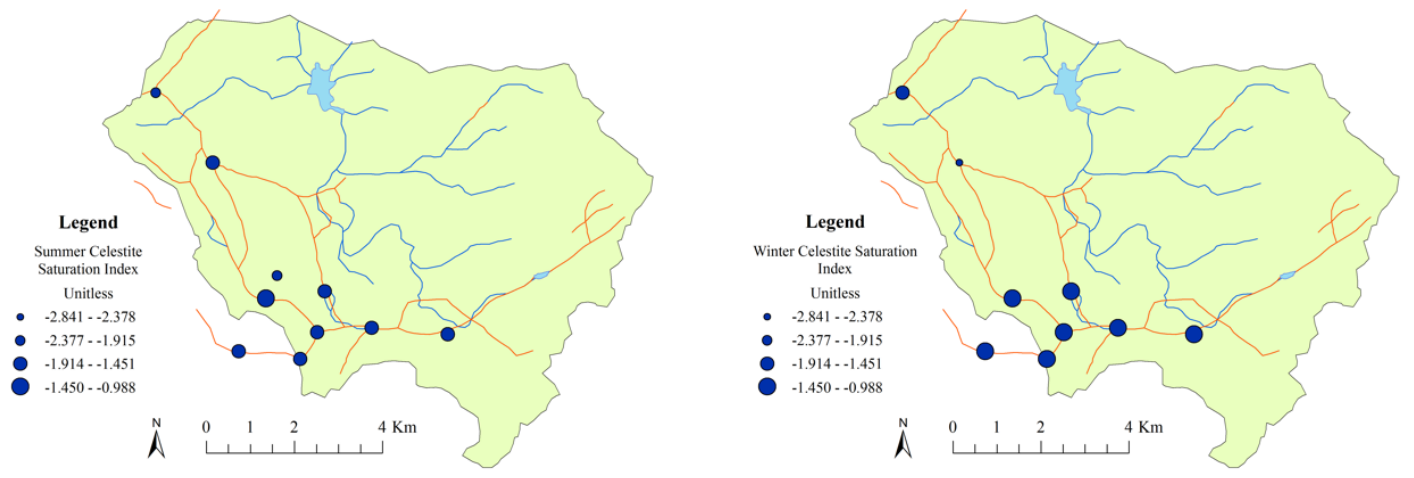

Figure 65: Maps comparing synoptic water sample saturation index with respect to celestite. Larger point diameter corresponds to a value that is closer to saturation. Summer samples are on the left, winter samples are on the right.

The time-series saturation index plots of calcite, dolomite, and strontianite are effectively identical, with the only differences between the three coming in the vertical shift to reflect Ca, Mg, or Sr concentrations (Figures 66, 67, and 68). Therefore, calcite had the highest saturation indices because Ca was most abundant, strontianite was furthest from saturation because Sr was least abundant, and SIdolomite (determined by magnesium) was in-between. It is important to note that, overall, these three plots mirror pH time-series measurements (Figure 36). The SI plots of the sulfate minerals, gypsum and celestite, both mirror the U-shaped pattern found in several of the other time-series ion plots, including $\mathrm{Sr}$ and $\mathrm{SO}_{4}$ (Figures 69 and 70). While all of the samples were notably undersaturated with respect to both of these minerals, SI celestite values were more negative than SIgypsum values because there was more dissolved Ca than Sr. 


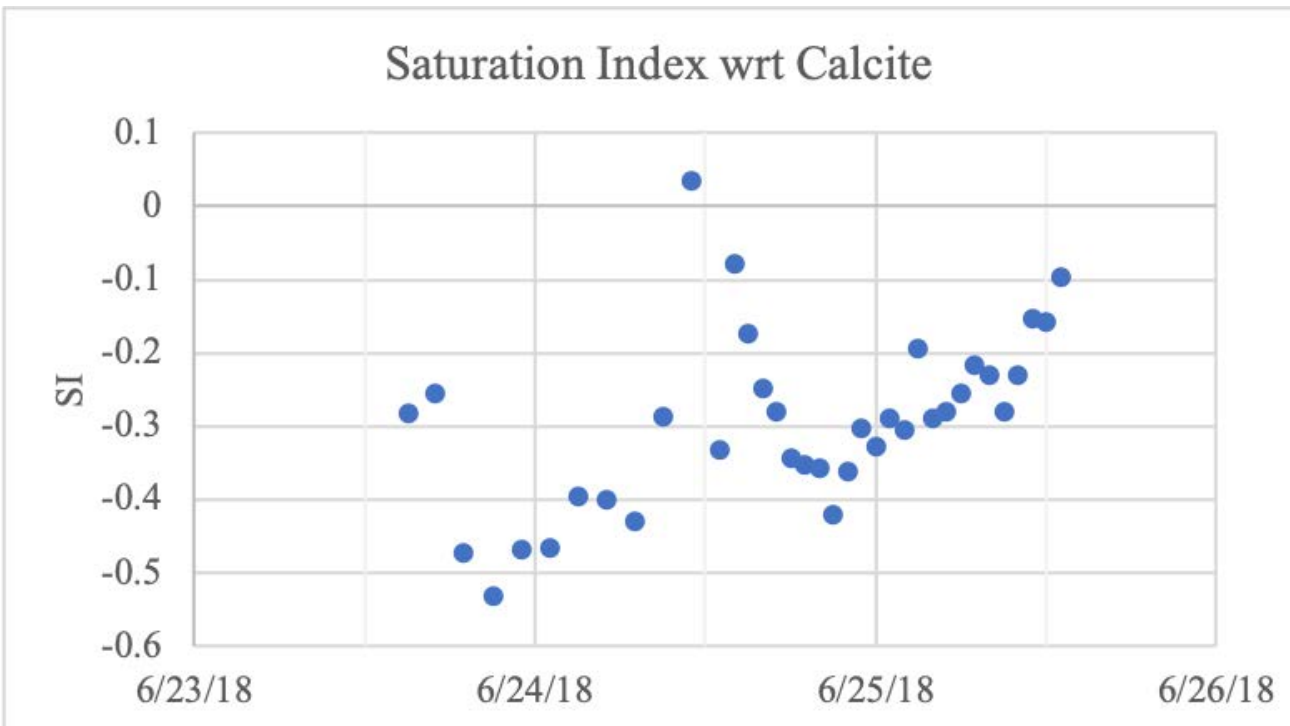

Figure 66: Plot showing water saturation index with respect to calcite during time series sampling.

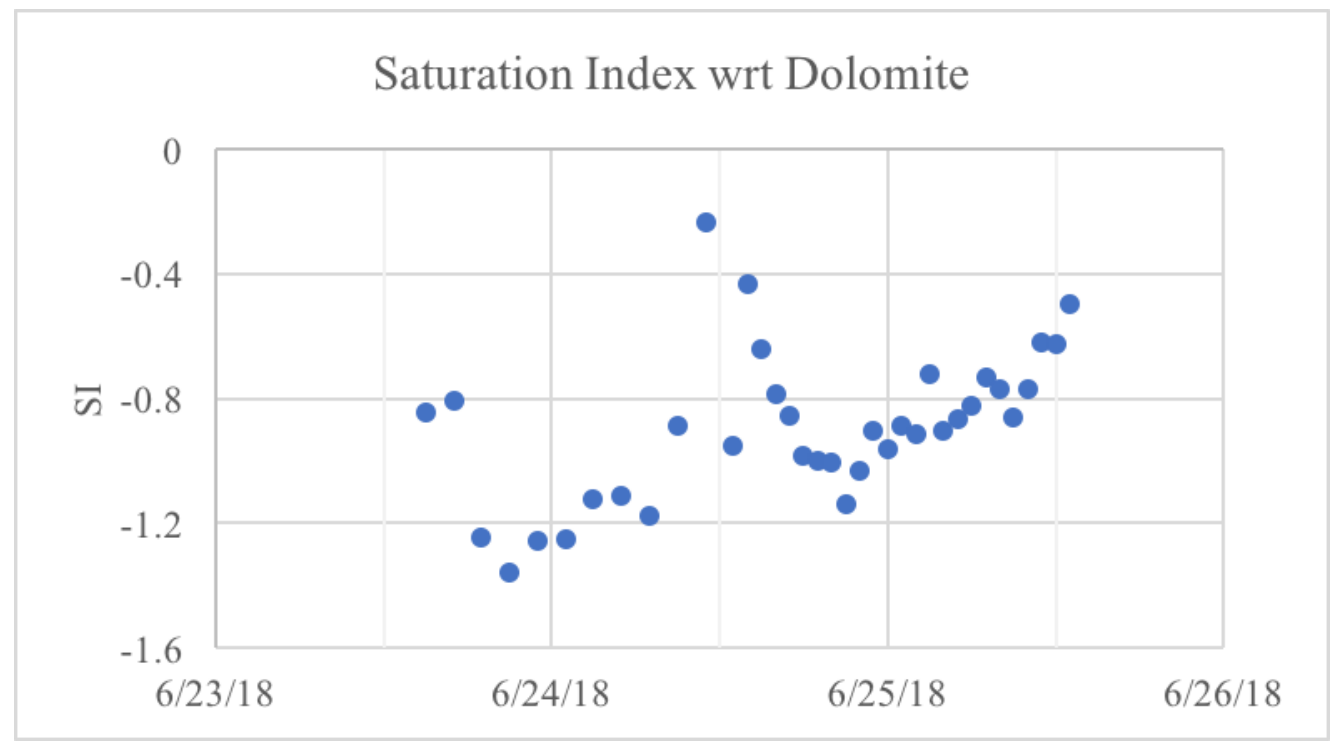

Figure 67: Plot showing water saturation index with respect to dolomite during time series sampling. 


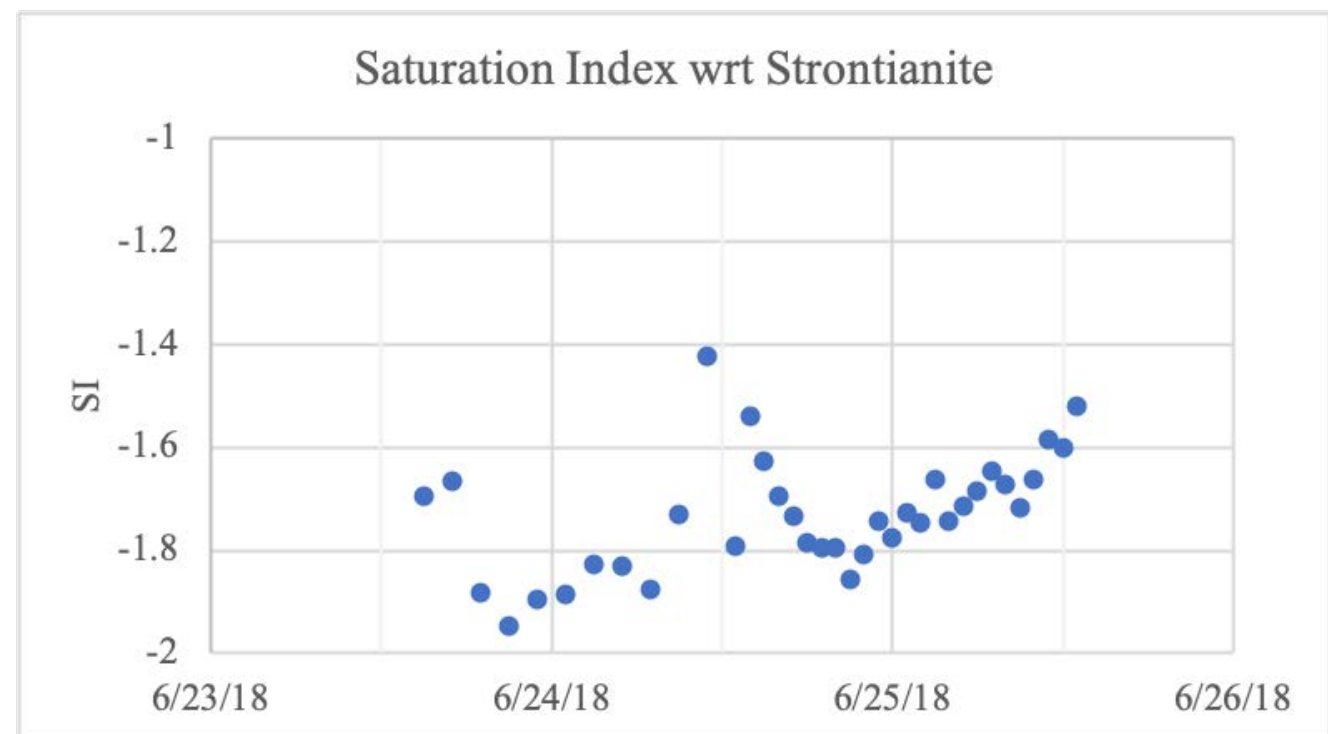

Figure 68: Plot showing water saturation index with respect to strontianite during time series sampling.

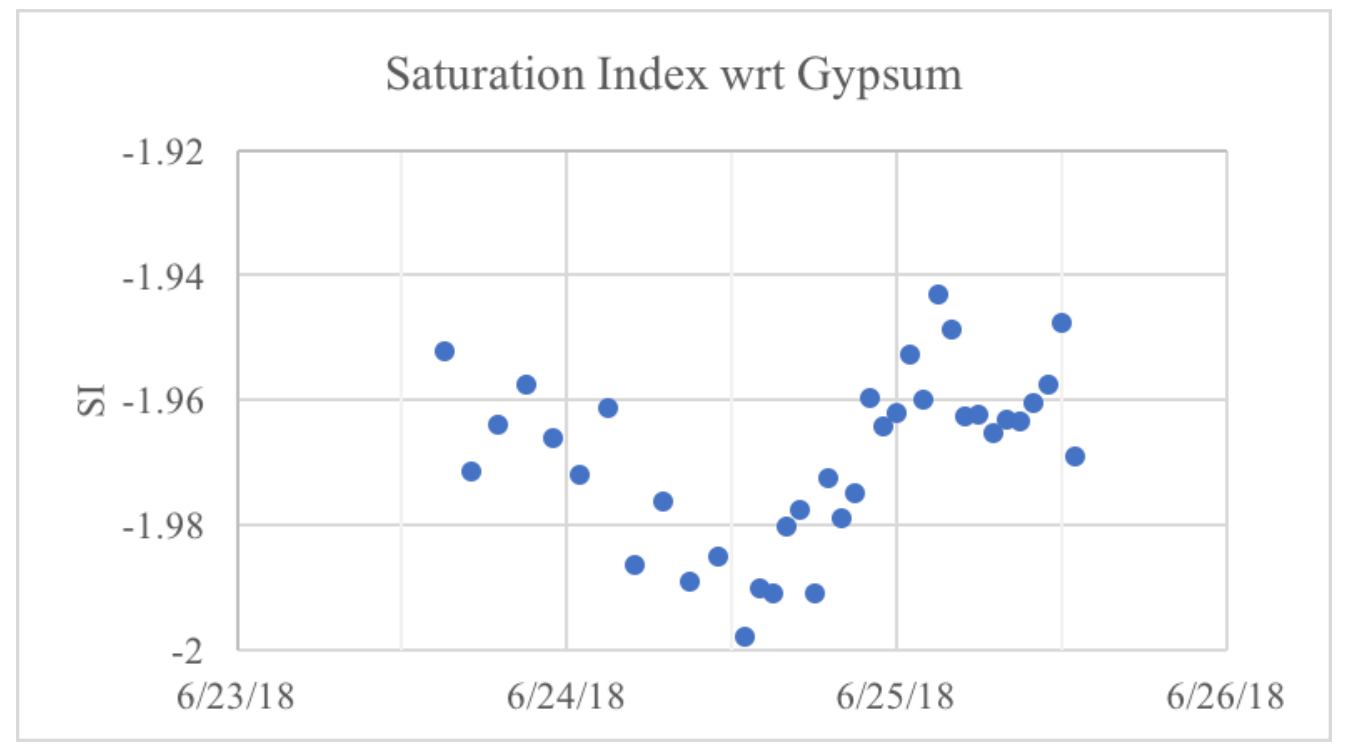

Figure 69: Plot showing water saturation index with respect to gypsum during time series sampling. 


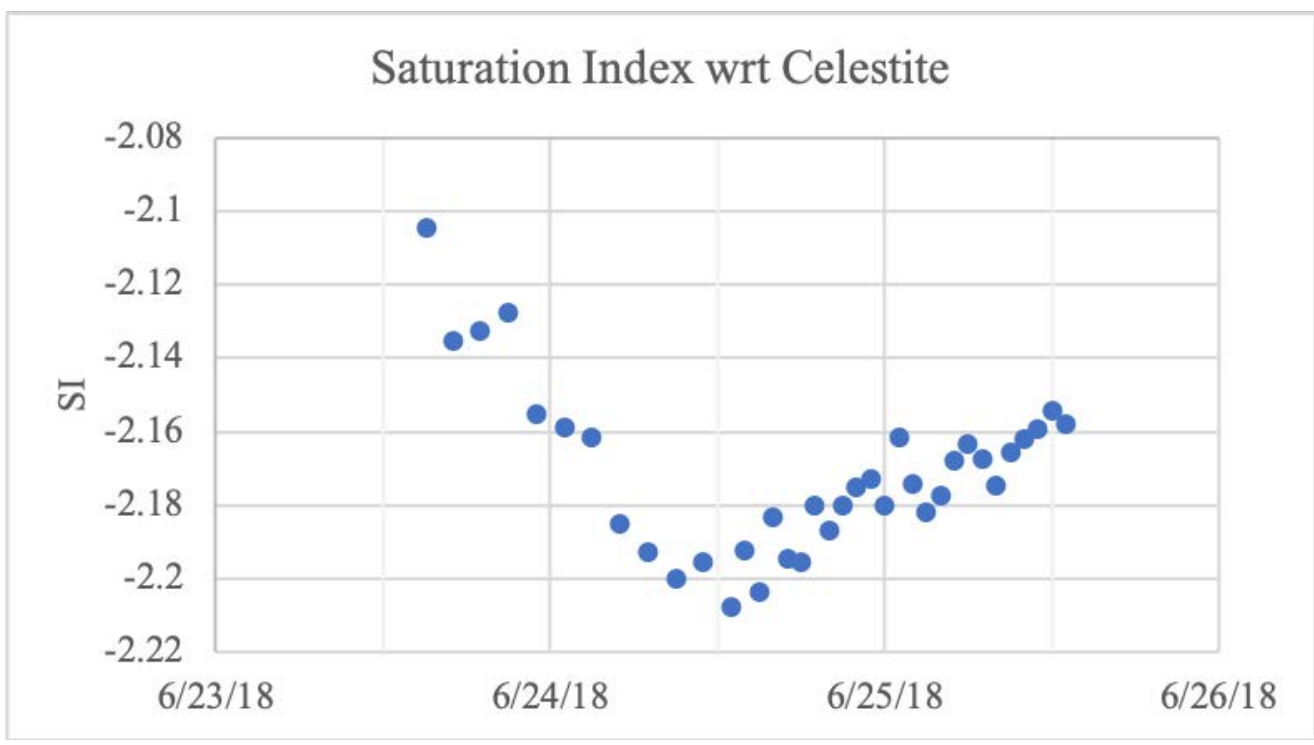

Figure 70: Plot showing water saturation index with respect to celestite during time series sampling.

\subsection{Inferences about Network Connectivity and Groundwater Flow from Tracers}

\subsubsection{Summer Baseflow Trace}

The presence of dye at both Daxing and Sanjianfang suggests that baseflow occurs along multiple pathways through the conduit system during monsoon season (Figure 71). Both the Laoheitan and Daxing bugs produced eluent that had enough dye to be visible to the naked eye. This is not surprising because dye was observed visually at both of these locations in the field. However, the bug recovered from Sanjianfang also produced eluent that had a visible amount of dye, although not as bright as Daxing or Laoheitan, which suggests that Sanjianfang is located on a secondary pathway. The negative dye result at Trash Spring is consistent with other factors suggesting that this spring is a high-level overflow and is not continuously connected to the conduit system. The negative result at Maokeng is likely a result of vandalism of the bug before the 
arrival of the dye because, based on the inferred conduit flowpaths, dye likely arrived via both conduit pathways (Figure 2).

The low-level detection of fluorescein in the background bug at Maoshuikeng could be a false positive as a result of cross-contamination. However, neither the field blank nor any of the other background samples tested positive. It is more likely that the background detection is an artifact of fluorescein from a source such as radiator coolant, which is plausible given that the location of the orifice is beneath a highway bridge. The bug deployed to capture the baseflow dye trace at Maoshuikeng showed a fluorescein peak approximately twice the intensity of the background peak, which indicates the tracer velocity from Xiao Shanba to Maoshuikeng was $\geq 2.6 \mathrm{~km} / \mathrm{d}(10.4 \mathrm{~km}$ in $4 \mathrm{~d})$.

The immediate water-level peak from the salt injection suggests a pressure pulse that moved through the system rapidly after the injection, displacing water already in the conduit system and forcing it out of the springs at Laoheitan. The fact that the water-level rise began $\sim 40$ min before the injection may indicate a coincidental input of water, such as from a paddy upstream of the sensor at Laoheitan. Close inspection of the hydrograph (Figure 53B) shows that an initial stage peak was receding at the time of injection at Xiao Shanba. The occurrence of a pressure pulse also suggests that the conduit system between Xiao Shanba and Laoheitan was at pipe-full conditions during the injection. Because the water arriving at Laoheitan during the pressure pulse was already moving through the system, there was no decrease in EC through dilution as would be expected if this were a storm-related stage increase. The arrival of injected water was signaled by the EC peak $21 \mathrm{~h}$ later. Based on this arrival and an inferred conduit length of $1.75 \mathrm{~km}$, the monsoonseason baseflow velocity between Xiao Shanba and Laoheitan was $\sim 2 \mathrm{~km} / \mathrm{d}$. 


\subsubsection{Summer Stormflow Trace}

There are several possibilities why no eosine dye was observed at Maoshuikeng in the water grab samples.

1. The concentration could have been too low $(<0.3 \mathrm{ppb}$ would realistically not be observable). It is possible that the concentration was never higher than the DL and enough dye adsorbed onto the charcoal for there to be a positive eosine spike when testing the bug but not the water.

2. The sampling interval was too short and the dye may have taken longer than $48 \mathrm{~h}$ to travel from Daxing to Maoshuikeng. This would put an upper bound on the flowrate of $150 \mathrm{~m} / \mathrm{h}(3.7 \mathrm{~km} / \mathrm{d})$ based on an inferred conduit distance of $7.4 \mathrm{~km}$ between Daxing and Maoshuikeng. This option is less likely because there was evidence of eosine in the Maoshuikeng bug, suggesting that at least some dye arrived within $48 \mathrm{~h}$ of injection.

3. Most or all of the dye was filtered out. Filtering the water samples was a mistake because even if the dye had sorbed to suspended sediment, it still would have been observable in the spectrofluorometer.

4. The dye degraded before it could be analyzed. Because the samples could not be tested at Guizhou Minzu University, they were brought back to Kentucky and tested $10 \mathrm{~d}$ after collection. The samples were not refrigerated for $\sim 36 \mathrm{~h}$ in transit, potentially accelerating degradation.

5. The majority of the dye discharged at the surface outlet of the catchment, termed “Houzhai” (location \#295), rather than at the Maoshuikeng rise. 
The bugs deployed at Maoshuikeng and Liugu to monitor the stormflow trace captured both fluorescein and eosine, suggesting that fluorescein had not been flushed from the system. The detection of both fluorescein and eosine for the bug at A Jiu Zhai, which was deployed from the start of the fluorescein trace until $48 \mathrm{~h}$ after the eosine trace

(a total of $8 \mathrm{~d}$ ), suggests that this dry valley is connected to the trunk conduit network, but only during high flow. The detection of eosine at Aliangzhai, which is inferred to be located on a tributary conduit flowing northeast to Daxing, suggests a gradient reversal in this area during storm events (Figure 72). This could mean that the karst feature at Aliangzhai is an estavelle (a swallet that temporarily becomes a spring). The minimum distance along which the gradient reversal would have occurred is $\sim 750 \mathrm{~m}$.

\subsubsection{Winter Baseflow Traces}

An unexpected result of the winter dye traces was the relatively rapid flow from Daxing towards Aliangzhai and Tian Guan (Figure 73). Both karst features were thought to be upgradient of Daxing, especially during baseflow conditions. The reason for the inferred gradient reversal was likely significant pumping that was observed at Tian Guan throughout the course of swapping the bugs. In general, inferred groundwater velocities were somewhat faster in summer than in winter, which is consistent with greater recharge and steeper hydraulic gradients during the wet season (Table 5).

There are several possible interpretations for the lack of dye observed at Maokeng. Groundwater velocity could have been $<0.6 \mathrm{~km} / \mathrm{d}$ ( $4.4 \mathrm{~km} / 8 \mathrm{~d})$. Alternatively, Sanjianfang and Maokeng may not be hydraulically connected during the dry season, but water from Sanjianfang would still be expected to discharge at Maoshuikeng. Because Sanjianfang and Daxing are comparable in distance from Maoshuikeng, the lack of 
detection of eosine (injected at Sanjianfang) and the detection of sulforhodamine B (injected at Daxing) suggest slower velocities along the northern branch of the conduit network than the southern branch. Additionally, the observation of sulforhodamine B at Maoshuikeng but not at Maokeng suggests that Maokeng may not be located along the trunk conduit linking Liugu to Maoshuikeng (Figure 73). Put a different way, sulforhodamine B may have bypassed Maokeng by flowing through a conduit located further west, possibly in connection with A Jiu Zhai. In general, karst conduit connectivity and groundwater velocity are a function of precipitation, with monsoon season rains increasing connectivity and water velocity. Therefore, future changes in rainfall could potentially increase flow variability between wet and dry seasons.

Table 5: Summary of inferred groundwater flow velocities under different hydraulic conditions.

\begin{tabular}{|l|l|}
\hline \multicolumn{2}{|c|}{ Summer baseflow velocities } \\
\hline Xiao Shanba to Laoheitan & $2 \mathrm{~km} / \mathrm{d}$ \\
\hline Xiao Shanba to Maoshuikeng & $\geq 2.6 \mathrm{~km} / \mathrm{d}$ \\
\hline \multicolumn{2}{|c|}{ Summer stormflow velocity } \\
\hline Daxing to Maoshuikeng & $>3.7 \mathrm{~km} / \mathrm{d}$ \\
\hline \multicolumn{2}{|c|}{ Winter baseflow velocities } \\
\hline Daxing to Aliangzhai & $>0.75 \mathrm{~km} / \mathrm{d}$ \\
\hline Daxing to Tian Guan & $1-2 \mathrm{~km} / \mathrm{d}$ \\
\hline Daxing to Liugu & $0.4-0.5 \mathrm{~km} / \mathrm{d}$ \\
\hline Daxing to Maoshuikeng & $0.9-1.5 \mathrm{~km} / \mathrm{d}$ \\
\hline Sanjianfang to Maokeng & $<0.6 \mathrm{~km} / \mathrm{d}$ \\
\hline
\end{tabular}




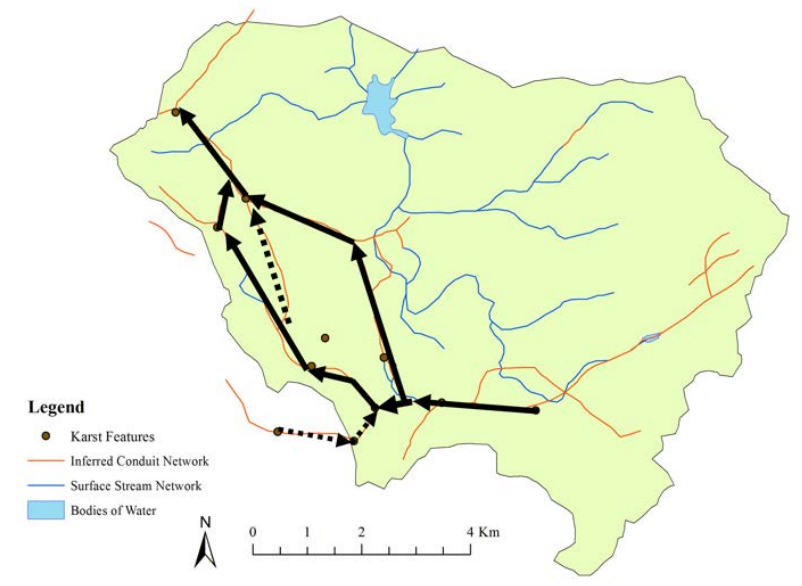

Figure 71: Conceptual map showing summer baseflow through the Houzhai catchment. Thicker arrows correspond to faster groundwater velocities.

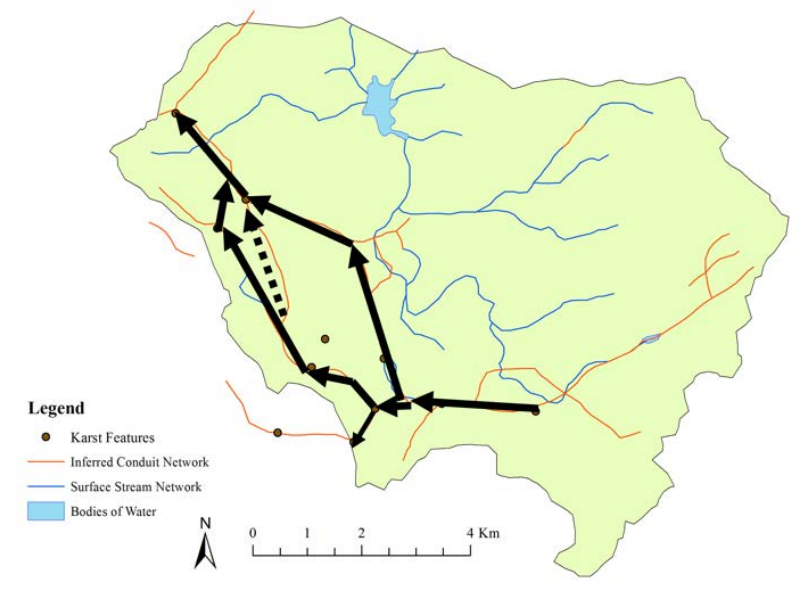

Figure 72: Conceptual map showing summer stormflow through the Houzhai catchment. Thicker arrows correspond to faster groundwater velocities.

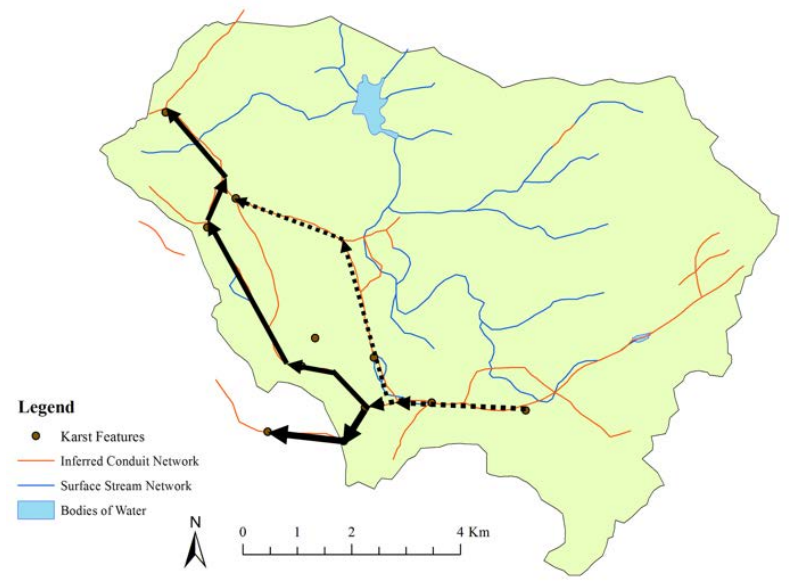

Figure 73: Conceptual map showing winter baseflow through the Houzhai catchment. Thicker arrows correspond to faster groundwater velocities. 


\section{CHAPTER 5. CONCLUSIONS}

The Houzhai catchment contains a complex karstic drainage network whose behavior varies at both event (hours to days) and seasonal time scales. During summer, monsoon rains cause the conduit network to fill and overflow passages to become active. During the winter, these overflow passages remain dry and some flowpaths, such as the one that connects Sanjianfang to the rest of the conduit network, seem to decrease in velocity significantly or become entirely hydrologically disconnected.

Carbonate dissolution is likely much more pronounced during the summer monsoon season due to the greater quantity of groundwater within the system. Saturationindex values, especially with respect to calcite, are generally more negative throughout the catchment during the summer. This means that the quantity of water within the system is keeping it aggressive, ready to dissolve the matrix. Summer $\delta^{13} C_{\text {DIC }}$ samples are more depleted than winter samples, indicating that oxidation of organic matter, especially from agricultural byproducts, such as rice leaves and corn stalks, is also more prevalent during the summer. Summer storm events seem to flush nutrients such as nitrate out of the catchment. Organic fertilizer, possibly including human waste, is likely making its way into the karst conduit system. This and the relatively fast groundwater flow velocities observed throughout the catchment pose significant contamination risks for local populations relying on groundwater for drinking water.

This research builds on previous studies within the Houzhai catchment by constraining values of groundwater velocity during summer and winter baseflow conditions as well as during summer stormflow events. Additionally, connectivity within 
the southern portion of the Houzhai catchment has also been better established. The collected data align well with preceding work completed at this site overall.

Further application of dye tracing techniques could significantly expand upon insights derived from this study. One potentially fruitful area of exploration could probe conduit connectivity and flow velocity during infrequent dry season storm events. While likely more challenging to capture due to their relative rarity, comparing the results of this type of dye trace to those conducted in this study could fill in some blanks within the overall picture. Additionally, more dye traces could also be employed to capture flow information about monsoonal storm events of varying magnitudes. The heterogeneous nature of the Houzhai catchment karst conduit network likely generates responses to storm events that vary nonlinearly with fluctuations in the amount, intensity, and location of precipitation within the catchment, even within a single monsoon season.

The findings of this study have several practical implications for water-resource management in the catchment. Tracer tests provide estimates of travel times along the conduit network under various conditions, which are useful for understanding the susceptibility of water supplies to contamination and for parameterizing groundwater flow models (Chen et al., 2013; Zhang et al., 2019; Zhang et al., 2017). In addition, the observed gradient reversal at Aliangzhai and Tian Guan in December indicates the potential for changes in flow rates and directions as a result of pumping. Consequently, there may be localized dewatering of conduits during the dry season. Overall, the combination of tracer injection with water-quality monitoring during baseflow (synoptically and seasonally) and stormflow provides a foundation for further research on 
conduit connectivity and groundwater velocity in the Houzhai catchment and elsewhere in the South China karst region. 


\section{APPENDICES}

APPENDIX A. Field Activity and Conduit Distances

Appendix Table A1: Summer 2018 field activity summary.

\begin{tabular}{|l|l|}
\hline Date & Summer 2018 Field Activity \\
\hline $6 / 8 / 18$ & Traveled to China \\
\hline $6 / 12 / 18$ & Drove to Puding \\
\hline $6 / 13 / 18$ & Field reconnaissance \\
\hline $6 / 14 / 18$ & Deployed background bugs \\
\hline $6 / 15 / 18$ & Deployed loggers \\
\hline $6 / 16 / 18$ & Synoptic sampling, swapped background bugs with round 1 bugs \\
\hline $6 / 17 / 18$ & Baseflow dye trace, salt injection \\
\hline $6 / 18 / 18$ & Observed dye at Laoheitan \\
\hline $6 / 19 / 18$ & Observed dye at Daxing \\
\hline $6 / 20 / 18$ & Trip to Guiyang to process background bugs \\
\hline $6 / 21 / 18$ & Swapped round 1 bugs with round 2 bugs \\
\hline $6 / 23 / 18$ & Stormflow dye trace, began time series sampling \\
\hline $6 / 24 / 18$ & Continued time series sampling \\
\hline $6 / 25 / 18$ & Finished time series sampling, retrieved round 2 bugs and loggers \\
\hline $6 / 26 / 18$ & Drove to Guiyang \\
\hline $6 / 29 / 18$ & Traveled back to USA \\
\hline
\end{tabular}


Appendix Table A2: Winter 2018 field activity summary.

\begin{tabular}{|l|l|}
\hline Date & Winter 2018 Field Activity \\
\hline $11 / 30 / 18$ & Traveled to China \\
\hline $12 / 2 / 18$ & Drove to Puding \\
\hline $12 / 3 / 18$ & Synoptic sampling, deployed background bugs \\
\hline $12 / 5 / 18$ & Dye traces, swapped background bugs with first set of bugs \\
\hline $12 / 6 / 18$ & Bug swap 1 \\
\hline $12 / 7 / 18$ & Bug swap 2 \\
\hline $12 / 8 / 18$ & Bug swap 3 \\
\hline $12 / 9 / 18$ & Bug swap 4 \\
\hline $12 / 10 / 18$ & Bug swap 5 \\
\hline $12 / 11 / 18$ & Bug swap 6, all bugs except for at Maokeng and Maoshuikeng \\
\hline $12 / 13 / 18$ & Retrieved Maokeng and Maoshuikeng bugs \\
\hline $12 / 14 / 18$ & Drove to Guiyang \\
\hline $12 / 15 / 18$ & Traveled back to USA \\
\hline
\end{tabular}


Appendix Table A3: Distance along inferred conduit network between karst features.

\begin{tabular}{|l|l|}
\hline Locations & Distance Between Locations (km) \\
\hline Xiao Shanba and Laoheitan & 1.75 \\
\hline Xiao Shanba and Daxing & 3.00 \\
\hline Daxing and Maoshuikeng & 7.36 \\
\hline Laoheitan and Daxing & 1.26 \\
\hline Aliangzhai and Daxing & 0.75 \\
\hline $\begin{array}{l}\text { Xiao Shanba and Maoshuikeng } \\
\text { (southern branch) }\end{array}$ & 10.39 \\
\hline $\begin{array}{l}\text { Xiao Shanba and Maoshuikeng } \\
\text { (northern branch) }\end{array}$ & 9.87 \\
\hline Sanjianfang and Maokeng & 4.39 \\
\hline Sanjianfeng and Maoshuikeng & 6.57 \\
\hline Tian Guan and Daxing & 2.16 \\
\hline Daxing and Liugu & 1.50 \\
\hline Tian Guan and Aliangzhai & 1.44 \\
\hline Maokeng and Maoshuikeng & 2.17 \\
\hline
\end{tabular}


APPENDIX B. Field Parameter and Synoptic Sample Data

Appendix Table B1: Summer field parameter data.

\begin{tabular}{|l|l|l|l|l|l|}
\hline Location Name & Location \# & $\begin{array}{l}\mathrm{pH} \\
(\text { Orion } \\
290 \mathrm{~A})\end{array}$ & $\begin{array}{l}\text { Water T } \\
(\text { Orion 290A }) \\
\left({ }^{\circ} \mathrm{C}\right)\end{array}$ & $\begin{array}{l}\text { Water T } \\
(\text { Orion 130) } \\
\left({ }^{\circ} \mathrm{C}\right)\end{array}$ & $\begin{array}{l}\text { Water T } \\
(\text { YSI 556) } \\
\left({ }^{\circ} \mathrm{C}\right)\end{array}$ \\
\hline Xiao Shanba & 98 & 7.012 & 22.2 & 22.0 & 22.94 \\
\hline Laoheitan & 109 & 7.216 & 20.1 & 18.4 & 18.25 \\
\hline Daxing & 121 & 7.197 & 18.6 & 18.4 & 18.26 \\
\hline Aliangzhai & 117 & 7.015 & 18.5 & 18.5 & 18.06 \\
\hline Tian Guan & 132 & 7.033 & 18.7 & 18.6 & 18.64 \\
\hline Sanjianfang & 123 & 6.765 & 17.9 & 17.8 & 17.72 \\
\hline Trash Spring & 127 & 6.841 & 17.8 & 17.8 & 17.64 \\
\hline Liugu & 129 & 6.992 & 19.8 & 19.8 & 20.82 \\
\hline Maokeng & 302 & 8.100 & 23.5 & 23.5 & 22.34 \\
\hline Maoshuikeng & 294 & 7.140 & 19.0 & 18.9 & 18.79 \\
\hline
\end{tabular}


Appendix Table B2: Summer field parameter data.

\begin{tabular}{|l|l|l|l|l|}
\hline Location Name & Location \# & $\begin{array}{l}\text { EC (Orion } \\
130) \\
(\mu \mathrm{S} / \mathrm{cm})\end{array}$ & $\begin{array}{l}\text { SC (YSI } \\
556) \\
(\mu \mathrm{S} / \mathrm{cm})\end{array}$ & $\begin{array}{l}\text { EC (YSI } \\
556) \\
(\mathrm{mS} / \mathrm{cm})\end{array}$ \\
\hline Xiao Shanba & 98 & 454 & 478 & 0.498 \\
\hline Laoheitan & 109 & 481 & 488 & 0.561 \\
\hline Daxing & 121 & 498 & 502 & 0.576 \\
\hline Aliangzhai & 117 & 492 & 500 & 0.576 \\
\hline Tian Guan & 132 & 508 & 509 & 0.580 \\
\hline Sanjianfang & 123 & 480 & 483 & 0.561 \\
\hline Trash Spring & 127 & 431 & 429 & 0.499 \\
\hline Liugu & 129 & 583 & 592 & 0.643 \\
\hline Maokeng & 302 & 517 & 496 & 0.523 \\
\hline Maoshuikeng & 294 & 457 & 452 & 0.512 \\
\hline
\end{tabular}

Appendix Table B3: Winter field parameter data.

\begin{tabular}{|l|l|l|l|l|l|}
\hline Location Name & Location \# & $\begin{array}{l}\mathrm{pH} \\
(\text { Orion } \\
290 \mathrm{~A})\end{array}$ & $\begin{array}{l}\text { Water T } \\
(\text { Orion } \\
290 \mathrm{~A})\left({ }^{\circ} \mathrm{C}\right)\end{array}$ & $\begin{array}{l}\text { Air T } \\
(\text { Orion } \\
290 \mathrm{~A})\left({ }^{\circ} \mathrm{C}\right)\end{array}$ & $\begin{array}{l}\text { Water T } \\
(\text { YSI 556) } \\
\left({ }^{\circ} \mathrm{C}\right)\end{array}$ \\
\hline Xiao Shanba & 98 & 6.914 & 14.7 & 14.6 & 14.81 \\
\hline Laoheitan & 109 & 6.947 & 18 & 16.9 & 17.76 \\
\hline Daxing & 121 & 7.355 & 17.4 & 17.2 & 17.26 \\
\hline Aliangzhai & 117 & 7.305 & 17.2 & 17.06 \\
\hline Tian Guan & 132 & 7.242 & 18.5 & 20.7 & 17.57 \\
\hline Sanjianfang & 123 & 6.72 & 17.4 & 16.7 & 17.08 \\
\hline Liugu & 129 & 7.126 & 17.9 & 15.9 & 17.51 \\
\hline Maokeng & 302 & 7.33 & 17.6 & 20.5 & 15.9 \\
\hline Maoshuikeng & 294 & 7.162 & 18.5 & 20.5 & 17.4 \\
\hline
\end{tabular}


Appendix Table B4: Winter field parameter data.

\begin{tabular}{|l|l|l|l|}
\hline Location Name & Location \# & $\begin{array}{l}\text { SC (YSI } \\
556) \\
(\mu S / c m)\end{array}$ & $\begin{array}{l}\text { EC (YSI } \\
(\mathrm{mS} / \mathrm{cm})\end{array}$ \\
\hline Xiao Shanba & 98 & 701 & 0.87 \\
\hline Laoheitan & 109 & 578 & 0.671 \\
\hline Daxing & 121 & 569 & 0.668 \\
\hline Aliangzhai & 117 & 582 & 0.686 \\
\hline Tian Guan & 132 & 569 & 0.663 \\
\hline Sanjianfang & 123 & 678 & 0.799 \\
\hline Liugu & 129 & 667 & 0.778 \\
\hline Maokeng & 302 & 366 & 0.443 \\
\hline Maoshuikeng & 294 & 451 & 0.528 \\
\hline
\end{tabular}

Appendix Table B5: Summer carbonate alkalinity data.

\begin{tabular}{|l|l|l|l|}
\hline Location Name & Location \# & Alk (mg/L CaCO 3$)$ & Alk Dup (mg/L CaCO3) \\
\hline Xiao Shanba & 98 & 141 & 138 \\
\hline Laoheitan & 109 & 191 & 190 \\
\hline Daxing & 121 & 190 & 190 \\
\hline Aliangzhai & 117 & 192 & 191 \\
\hline Tian Guan & 132 & 190 & 190 \\
\hline Sanjianfang & 123 & 188 & 188 \\
\hline Trash Spring & 127 & 172 & 172 \\
\hline Liugu & 129 & 183 & 183 \\
\hline A Jiu Zhai & N/A & 173 & 173 \\
\hline Maokeng & 302 & 179 & 138 \\
\hline Maoshuikeng & 294 & 141 & \\
\hline
\end{tabular}


Appendix Table B6: Winter carbonate alkalinity data.

\begin{tabular}{|l|l|l|}
\hline Location Name & Location \# & Alk (mg/L CaCO3) \\
\hline Xiao Shanba & 98 & 253 \\
\hline Laoheitan & 109 & 210 \\
\hline Daxing & 121 & 212 \\
\hline Aliangzhai & 117 & 209 \\
\hline Tian Guan & 132 & 208 \\
\hline Sanjianfang & 123 & 257 \\
\hline Liugu & 129 & 205 \\
\hline Maokeng & 302 & 197 \\
\hline Maoshuikeng & 294 & 190 \\
\hline
\end{tabular}

Appendix Table B7: Summer synoptic sample anion data. Note Maokeng data are from UK Plant and Soil Sciences IC.

\begin{tabular}{|l|l|l|l|l|l|l|l|}
\hline Location Name & Location \# & $\begin{array}{l}\mathrm{F}^{-} \\
(\mathrm{mg} / \mathrm{L})\end{array}$ & $\begin{array}{l}\mathrm{Cl}^{-} \\
(\mathrm{mg} / \mathrm{L})\end{array}$ & $\begin{array}{l}\mathrm{NO}_{3}^{-} \\
(\mathrm{mg} / \mathrm{L})\end{array}$ & $\begin{array}{l}\mathrm{SO}_{4}{ }^{--} \\
(\mathrm{mg} / \mathrm{L})\end{array}$ & $\begin{array}{l}\mathrm{NO}_{2}^{-} \\
(\mathrm{mg} / \mathrm{L})\end{array}$ & $\begin{array}{l}\mathrm{Br}^{-} \\
(\mathrm{mg} / \mathrm{L})\end{array}$ \\
\hline Xiao Shanba & 98 & 0.31 & 6.30 & 13.74 & 58.61 & 0.03 & $<0.2$ \\
\hline Laoheitan & 109 & 0.24 & 8.26 & 24.09 & 64.54 & $<0.05$ & $<0.2$ \\
\hline Daxing & 121 & 0.25 & 8.14 & 25.72 & 69.88 & $<0.05$ & $<0.2$ \\
\hline Aliangzhai & 117 & 0.26 & 8.52 & 26.22 & 70.11 & $<0.05$ & $<0.2$ \\
\hline Tian Guan & 132 & 0.24 & 8.56 & 26.96 & 69.32 & $<0.05$ & $<0.2$ \\
\hline Sanjianfang & 123 & 0.18 & 9.15 & 25.41 & 61.75 & $<0.05$ & $<0.2$ \\
\hline Trash Spring & 127 & 0.22 & 12.82 & 16.67 & 46.62 & $<0.05$ & $<0.2$ \\
\hline Liugu & 129 & 0.34 & 9.48 & 27.56 & 110.63 & $<0.05$ & $<0.2$ \\
\hline Maokeng & 302 & 0.26 & 9.43 & 19.55 & 64.26 & 0.53 & $<0.2$ \\
\hline Maoshuikeng & 294 & 0.22 & 7.22 & 24.68 & 50.71 & $<0.05$ & $<0.2$ \\
\hline
\end{tabular}


Appendix Table B8: Summer synoptic sample metal(loid) data.

\begin{tabular}{|l|l|l|l|l|l|l|l|}
\hline Location Name & Location \# & $\begin{array}{l}\mathrm{Ca}^{2+} \\
(\mathrm{mg} / \mathrm{L})\end{array}$ & $\begin{array}{l}\mathrm{K}^{+} \\
(\mathrm{mg} / \mathrm{L})\end{array}$ & $\begin{array}{l}\mathrm{Mg}^{2+} \\
(\mathrm{mg} / \mathrm{L})\end{array}$ & $\begin{array}{l}\mathrm{Na}^{+} \\
(\mathrm{mg} / \mathrm{L})\end{array}$ & $\begin{array}{l}\mathrm{SiO}_{2}{ }^{2} \\
(\mathrm{mg} / \mathrm{L})\end{array}$ & $\begin{array}{l}\mathrm{Sr}^{2+} \\
(\mathrm{mg} / \mathrm{L})\end{array}$ \\
\hline Xiao Shanba & 98 & 61.09 & 8.70 & 11.66 & 6.08 & 9.34 & 1.23 \\
\hline Laoheitan & 109 & 79.30 & 3.56 & 18.70 & 4.21 & 4.87 & 1.65 \\
\hline Daxing & 121 & 84.26 & 3.47 & 17.94 & 3.71 & 5.26 & 1.79 \\
\hline Aliangzhai & 117 & 85.47 & 3.56 & 17.96 & 3.80 & 5.27 & 1.82 \\
\hline Tian Guan & 132 & 86.91 & 3.51 & 17.05 & 3.62 & 5.36 & 1.78 \\
\hline Sanjianfang & 123 & 85.00 & 3.19 & 15.95 & 3.27 & 5.59 & 1.67 \\
\hline Trash Spring & 127 & 81.59 & 2.32 & 10.67 & 1.87 & 4.77 & 1.17 \\
\hline Liugu & 129 & 93.93 & 5.95 & 18.82 & 5.41 & 6.04 & 2.30 \\
\hline Maokeng & 302 & 75.24 & 4.96 & 16.74 & 4.53 & 5.47 & 1.51 \\
\hline Maoshuikeng & 294 & 70.30 & 2.63 & 19.20 & 3.37 & 4.40 & 1.00 \\
\hline
\end{tabular}

Appendix Table B9: Summer synoptic sample calculated values. CBE = Charge Balance $\%$ Error

\begin{tabular}{|l|l|l|l|l|l|l|l|}
\hline Location Name & $\mathrm{Mg} / \mathrm{Ca}$ & $\mathrm{SI}_{\text {calcite }}$ & $\mathrm{SI}_{\text {dolomite }}$ & $\mathrm{SI}_{\text {strontianite }}$ & $\mathrm{SI}_{\text {gypsum }}$ & $\mathrm{SI}_{\text {celestite }}$ & $\mathrm{CBE}$ \\
\hline Xiao Shanba & 0.31 & -0.46 & -1.34 & -1.70 & -1.84 & -1.82 & 0.81 \\
\hline Laoheitan & 0.39 & -0.07 & -0.49 & -1.28 & -1.74 & -1.71 & 0.12 \\
\hline Daxing & 0.35 & -0.09 & -0.59 & -1.28 & -1.68 & -1.65 & 0.56 \\
\hline Aliangzhai & 0.35 & -0.26 & -0.95 & -1.45 & -1.67 & -1.65 & 0.59 \\
\hline Tian Guan & 0.32 & -0.24 & -0.92 & -1.45 & -1.67 & -1.66 & 0.88 \\
\hline Sanjianfang & 0.31 & -0.53 & -1.53 & -1.75 & -1.72 & -1.73 & 0.88 \\
\hline Trash Spring & 0.22 & -0.49 & -1.62 & -1.85 & -1.83 & -1.98 & 0.69 \\
\hline Liugu & 0.33 & -0.27 & -0.96 & -1.40 & -1.46 & -1.37 & -0.12 \\
\hline Maokeng & 0.37 & 0.78 & 1.24 & -0.46 & -1.76 & -1.73 & 0.86 \\
\hline Maoshuikeng & 0.45 & -0.23 & -0.76 & -1.60 & -1.87 & -2.02 & 0.78 \\
\hline
\end{tabular}


Appendix Table B10: Winter synoptic sample anion data.

\begin{tabular}{|l|l|l|l|l|l|l|l|}
\hline Location Name & Location \# & $\begin{array}{l}\mathrm{F}^{-} \\
(\mathrm{mg} / \mathrm{L})\end{array}$ & $\begin{array}{l}\mathrm{Cl}^{-} \\
(\mathrm{mg} / \mathrm{L})\end{array}$ & $\begin{array}{l}\mathrm{NO}_{3}^{-} \\
(\mathrm{mg} / \mathrm{L})\end{array}$ & $\begin{array}{l}\mathrm{SO}_{4}^{2-} \\
(\mathrm{mg} / \mathrm{L})\end{array}$ & $\begin{array}{l}\mathrm{NO}_{2}^{-} \\
(\mathrm{mg} / \mathrm{L})\end{array}$ & $\begin{array}{l}\mathrm{Br}^{-} \\
(\mathrm{mg} / \mathrm{L})\end{array}$ \\
\hline Xiao Shanba & 98 & 0.27 & 57.34 & 16.25 & 136.88 & $<0.05$ & $<0.2$ \\
\hline Laoheitan & 109 & 0.34 & 11.91 & 18.20 & 139.84 & $<0.05$ & $<0.2$ \\
\hline Daxing & 121 & 0.36 & 11.34 & 16.22 & 138.27 & $<0.05$ & $<0.2$ \\
\hline Aliangzhai & 117 & 0.36 & 11.61 & 16.48 & 146.32 & $<0.05$ & $<0.2$ \\
\hline Tian Guan & 132 & 0.37 & 12.53 & 17.80 & 130.81 & $<0.05$ & $<0.2$ \\
\hline Sanjianfang & 123 & 0.26 & 14.22 & 17.41 & 107.03 & $<0.05$ & $<0.2$ \\
\hline Liugu & 129 & 0.78 & 18.82 & 16.67 & 191.27 & $<0.05$ & $<0.2$ \\
\hline Maokeng & 302 & 0.19 & 4.79 & 20.72 & 28.20 & $<0.05$ & $<0.2$ \\
\hline Maoshuikeng & 294 & 0.23 & 9.95 & 14.52 & 79.32 & $<0.05$ & $<0.2$ \\
\hline
\end{tabular}

Appendix Table B11: Winter synoptic sample metal(loid) data.

\begin{tabular}{|l|l|l|l|l|l|l|l|}
\hline Location Name & Location \# & $\begin{array}{l}\mathrm{Ca}^{2+} \\
(\mathrm{mg} / \mathrm{L})\end{array}$ & $\begin{array}{l}\mathrm{K}^{+} \\
(\mathrm{mg} / \mathrm{L})\end{array}$ & $\begin{array}{l}\mathrm{Mg}^{2+} \\
(\mathrm{mg} / \mathrm{L})\end{array}$ & $\begin{array}{l}\mathrm{Na}^{+} \\
(\mathrm{mg} / \mathrm{L})\end{array}$ & $\begin{array}{l}\mathrm{SiO}_{2}{ }^{2} \\
(\mathrm{mg} / \mathrm{L})\end{array}$ & $\begin{array}{l}\mathrm{Sr}^{2+} \\
(\mathrm{mg} / \mathrm{L})\end{array}$ \\
\hline Xiao Shanba & 98 & 105.99 & 8.26 & 28.17 & 35.01 & 5.28 & 2.39 \\
\hline Laoheitan & 109 & 104.23 & 5.84 & 23.41 & 8.18 & 5.30 & 3.09 \\
\hline Daxing & 121 & 94.73 & 4.79 & 23.76 & 7.53 & 4.97 & 3.40 \\
\hline Aliangzhai & 117 & 94.73 & 4.63 & 23.37 & 7.77 & 5.05 & 3.37 \\
\hline Tian Guan & 132 & 107.01 & 4.72 & 22.91 & 6.66 & 4.62 & 3.39 \\
\hline Sanjianfang & 123 & 110.76 & 5.01 & 25.95 & 5.38 & 5.45 & 2.33 \\
\hline Liugu & 129 & 117.89 & 11.20 & 24.95 & 22.20 & 5.42 & 3.82 \\
\hline Maokeng & 302 & 59.92 & 1.11 & 24.99 & 1.97 & 3.01 & 0.27 \\
\hline Maoshuikeng & 294 & 68.21 & 1.96 & 25.00 & 5.80 & 3.07 & 0.95 \\
\hline
\end{tabular}


Appendix Table B12: Winter synoptic sample calculated values. CBE = Charge Balance \% Error

\begin{tabular}{|l|l|l|l|l|l|l|l|}
\hline Location Name & $\mathrm{Mg} / \mathrm{Ca}$ & $\mathrm{SI}_{\text {calcite }}$ & $\mathrm{SI}_{\text {dolomite }}$ & $\mathrm{SI}_{\text {strontianite }}$ & $\mathrm{SI}_{\text {gypsum }}$ & $\mathrm{SI}_{\text {celestite }}$ & $\mathrm{CBE}$ \\
\hline Xiao Shanba & 0.44 & -0.26 & -0.89 & -1.40 & -1.36 & -1.34 & -2.26 \\
\hline Laoheitan & 0.37 & -0.26 & -0.91 & -1.30 & -1.34 & -1.18 & -0.37 \\
\hline Daxing & 0.41 & 0.11 & -0.14 & -0.85 & -1.38 & -1.13 & -3.71 \\
\hline Aliangzhai & 0.41 & 0.05 & -0.28 & -0.91 & -1.36 & -1.12 & -4.77 \\
\hline Tian Guan & 0.35 & 0.04 & -0.34 & -0.97 & -1.36 & -1.17 & 1.24 \\
\hline Sanjianfang & 0.39 & -0.38 & -1.15 & -1.56 & -1.44 & -1.43 & 0.12 \\
\hline Liugu & 0.35 & -0.06 & -0.56 & -1.06 & -1.19 & -0.99 & 2.17 \\
\hline Maokeng & 0.69 & -0.11 & -0.37 & -1.95 & -2.18 & -2.84 & 1.67 \\
\hline Maoshuikeng & 0.60 & -0.24 & -0.66 & -1.60 & -1.71 & -1.87 & -1.73 \\
\hline
\end{tabular}

Appendix Table B13: Summer synoptic sample isotope data.

\begin{tabular}{|l|l|l|l|l|l|l|}
\hline Location Name & $\begin{array}{l}\delta^{13} \text { CDIC } \\
(\% \text { PDB })\end{array}$ & SD & $\begin{array}{l}\delta^{2} \mathrm{H}(\% \text { ) } \\
\text { VSMOW) }\end{array}$ & SD & $\begin{array}{l}\delta^{18} \text { O (\%o } \\
\text { VSMOW })\end{array}$ & SD \\
\hline Xiao Shanba & -12.31 & 0.011 & -67.10 & 0.23 & -9.76 & 0.05 \\
\hline Laoheitan & -13.21 & 0.01 & -50.06 & 0.09 & -7.66 & 0.01 \\
\hline Daxing & -12.83 & 0.017 & -50.22 & 0.15 & -7.54 & 0.07 \\
\hline Aliangzhai & -12.98 & 0.006 & -49.89 & 0.39 & -7.49 & 0.04 \\
\hline Tian Guan & -12.43 & 0.023 & -50.11 & 0.15 & -7.48 & 0.05 \\
\hline Sanjianfang & -12.05 & 0.015 & -50.74 & 0.08 & -7.48 & 0.05 \\
\hline Trash Spring & -12.08 & 0.006 & -47.54 & 0.36 & -6.89 & 0.04 \\
\hline Liugu & -12.24 & 0.026 & -51.04 & 0.21 & -7.69 & 0.05 \\
\hline Maokeng & -8.71 & 0.007 & -50.21 & 0.2 & -7.57 & 0.03 \\
\hline Maoshuikeng & -11.23 & 0.048 & -52.46 & 0.15 & -7.90 & 0.04 \\
\hline
\end{tabular}


Appendix Table B14: Winter synoptic sample isotope data.

\begin{tabular}{|l|l|l|l|l|l|l|}
\hline Location Name & $\begin{array}{l}\delta^{13} \text { CDIC } \\
\text { (\%o PDB) }\end{array}$ & SD & $\begin{array}{l}\delta^{2} \mathrm{H}(\% \circ \\
\text { VSMOW) }\end{array}$ & SD & $\begin{array}{l}\delta^{18} \mathrm{O}(\% \circ \\
\text { VSMOW) }\end{array}$ & SD \\
\hline Xiao Shanba & -11.65 & 0.034 & -55.44 & 0.1 & -8.11 & 0.03 \\
\hline Laoheitan & -12.27 & 0.024 & -56.91 & 0.1 & -8.28 & 0.09 \\
\hline Daxing & -11.94 & 0.037 & -56.12 & 0.18 & -8.12 & 0.04 \\
\hline Aliangzhai & -11.80 & 0.014 & -56.33 & 0.31 & -8.36 & 0.15 \\
\hline Tian Guan & -11.77 & 0.01 & -55.54 & 0.11 & -8.15 & 0.04 \\
\hline Sanjianfang & -11.77 & 0.022 & -51.98 & 0.34 & -7.41 & 0.02 \\
\hline Liugu & -11.22 & 0.011 & -55.14 & 0.2 & -8.00 & 0.05 \\
\hline Maokeng & -8.82 & 0.018 & -57.02 & 0.13 & -8.35 & 0.03 \\
\hline Maoshuikeng & -11.39 & 0.014 & -55.59 & 0.22 & -7.98 & 0.06 \\
\hline
\end{tabular}




\section{APPENDIX C. Time Series Data}

Appendix Table C1: Time series logger data $370 \mathrm{~m}$ downstream of Maoshuikeng. Dates and times are local. HAI $=$ Hours after injection

\begin{tabular}{|c|c|c|c|c|c|}
\hline Sample \# & Date and time & HAI & $\begin{array}{l}\text { EC } \\
(\mu \mathrm{S} / \mathrm{cm})\end{array}$ & $\mathrm{T}\left({ }^{\circ} \mathrm{C}\right)$ & WL (m) \\
\hline 0 & 6/23/18 13:00 & 0 & 464.4 & 20.27 & 0.986 \\
\hline 1 & 6/23/18 15:05 & 2.08 & 462 & 20.25 & 0.884 \\
\hline 2 & 6/23/18 17:00 & 4 & 459.8 & 20.13 & 0.823 \\
\hline 3 & 6/23/18 19:00 & 6 & 459.1 & 20.07 & 0.748 \\
\hline 4 & 6/23/18 21:00 & 8 & 459.8 & 20.01 & 0.695 \\
\hline 5 & 6/23/18 23:00 & 10 & 460.6 & 19.95 & 0.648 \\
\hline 6 & 6/24/18 1:00 & 12 & 460.5 & 19.89 & 0.613 \\
\hline 7 & 6/24/18 3:00 & 14 & 459.9 & 19.83 & 0.583 \\
\hline 8 & 6/24/18 5:00 & 16 & 456.8 & 19.77 & 0.554 \\
\hline 9 & 6/24/18 7:00 & 18 & 453 & 19.73 & 0.53 \\
\hline 10 & 6/24/18 9:00 & 20 & 451.6 & 19.72 & 0.511 \\
\hline 11 & 6/24/18 11:00 & 22 & 451.7 & 19.77 & 0.496 \\
\hline 12 & 6/24/18 13:00 & 24 & 453.2 & 19.81 & 0.485 \\
\hline 13 & 6/24/18 14:00 & 25 & 454.5 & 19.87 & 0.474 \\
\hline 14 & 6/24/18 15:00 & 26 & 454.6 & 19.77 & 0.473 \\
\hline 15 & 6/24/18 16:00 & 27 & 455.7 & 19.76 & 0.474 \\
\hline 16 & 6/24/18 17:00 & 28 & 457.3 & 19.79 & 0.47 \\
\hline 17 & 6/24/18 18:00 & 29 & 457.8 & 19.77 & 0.466 \\
\hline 18 & 6/24/18 19:00 & 30 & 459.3 & 19.76 & 0.455 \\
\hline 19 & $6 / 24 / 18$ 20:00 & 31 & 460.6 & 19.73 & 0.45 \\
\hline 20 & 6/24/18 21:00 & 32 & 461.7 & 19.72 & 0.447 \\
\hline 21 & 6/24/18 22:00 & 33 & 462.7 & 19.73 & 0.44 \\
\hline 22 & 6/24/18 23:00 & 34 & 463.5 & 19.73 & 0.435 \\
\hline
\end{tabular}




\begin{tabular}{|l|l|l|l|l|l|}
\hline 23 & $6 / 25 / 180: 00$ & 35 & 464.1 & 19.73 & 0.431 \\
\hline 24 & $6 / 25 / 181: 00$ & 36 & 464.7 & 19.73 & 0.425 \\
\hline 25 & $6 / 25 / 182: 00$ & 37 & 464.9 & 19.72 & 0.422 \\
\hline 26 & $6 / 25 / 183: 00$ & 38 & 465.4 & 19.72 & 0.418 \\
\hline 27 & $6 / 25 / 184: 00$ & 39 & 465.7 & 19.71 & 0.414 \\
\hline 28 & $6 / 25 / 185: 00$ & 40 & 466 & 19.69 & 0.408 \\
\hline 29 & $6 / 25 / 186: 00$ & 41 & 466.1 & 19.68 & 0.406 \\
\hline 30 & $6 / 25 / 187: 00$ & 42 & 466.1 & 19.67 & 0.406 \\
\hline 31 & $6 / 25 / 18$ 8:00 & 43 & 466.5 & 19.67 & 0.399 \\
\hline 32 & $6 / 25 / 189: 00$ & 44 & 466.7 & 19.68 & 0.394 \\
\hline 33 & $6 / 25 / 1810: 00$ & 45 & 467.3 & 19.71 & 0.39 \\
\hline 34 & $6 / 25 / 1811: 00$ & 46 & 467.5 & 19.71 & 0.39 \\
\hline 35 & $6 / 25 / 1812: 00$ & 47 & 468.6 & 19.8 & 0.384 \\
\hline 36 & $6 / 25 / 1813: 00$ & 48 & 468.6 & 19.8 & 0.379 \\
\hline
\end{tabular}

Appendix Table C2: Time series field parameter data from Maoshuikeng (location \#294).

\begin{tabular}{|l|l|l|l|l|}
\hline Sample \# & $\begin{array}{l}\mathrm{EC} \\
(\mu \mathrm{S} / \mathrm{cm})\end{array}$ & $\mathrm{T}\left({ }^{\circ} \mathrm{C}\right)$ & $\mathrm{pH}$ & Alk (mg/L CaCO$)$ \\
\hline 1 & 454 & 22.7 & 7.096 & 162 \\
\hline 2 & 436 & 21.2 & 7.154 & 163 \\
\hline 3 & 434 & 20.9 & 6.937 & 163 \\
\hline 4 & 433 & 21.1 & 6.875 & 162 \\
\hline 5 & 429 & 20.4 & 6.941 & 163 \\
\hline 6 & 430 & 20.2 & 6.948 & 163 \\
\hline 7 & 425 & 20.1 & 7.000 & 165 \\
\hline 8 & 421 & 20.1 & 7.014 & 165 \\
\hline 9 & 418 & 20.0 & 6.989 & 161 \\
\hline 10 & 419 & 20.1 & 7.134 & 162 \\
\hline
\end{tabular}




\begin{tabular}{|c|c|c|c|c|}
\hline 11 & 428 & 21.2 & 7.436 & 162 \\
\hline 12 & 436 & 21.6 & 7.065 & 165 \\
\hline 13 & 445 & 22.47 & 7.302 & 165 \\
\hline 14 & 427 & 20.84 & 7.230 & 166 \\
\hline 15 & 432 & 21.07 & 7.162 & 161 \\
\hline 16 & 427 & 20.50 & 7.129 & 166 \\
\hline 17 & 426 & 20.38 & 7.072 & 164 \\
\hline 18 & 425 & 20.17 & 7.060 & 166 \\
\hline 19 & 422 & 20.01 & 7.058 & 166 \\
\hline 20 & 423 & 19.89 & 6.996 & 167 \\
\hline 21 & 424 & 19.88 & 7.042 & 168 \\
\hline 22 & 425 & 20.00 & 7.105 & 168 \\
\hline 23 & 425 & 19.80 & 7.075 & 169 \\
\hline 24 & 426 & 19.83 & 7.112 & 169 \\
\hline 25 & 424 & 19.66 & 7.109 & 166 \\
\hline 26 & 424 & 19.76 & 7.187 & 170 \\
\hline 27 & 425 & 19.64 & 7.105 & 169 \\
\hline 28 & 424 & 19.67 & 7.129 & 169 \\
\hline 29 & 424 & 19.56 & 7.158 & 170 \\
\hline 30 & 426 & 19.70 & 7.195 & 169 \\
\hline 31 & 426 & 19.84 & 7.179 & 168 \\
\hline 32 & 434 & 20.30 & 7.114 & 170 \\
\hline 33 & 433 & 19.92 & 7.172 & 170 \\
\hline 34 & 432 & 19.98 & 7.244 & 169 \\
\hline 35 & 439 & 20.56 & 7.227 & 169 \\
\hline 36 & 435 & 20.14 & 7.263 & 190 \\
\hline
\end{tabular}


Appendix Table C3: Time series water sample anion data from Maoshuikeng (location \#294).

\begin{tabular}{|l|l|l|l|l|l|l|}
\hline Sample \# & $\begin{array}{l}\mathrm{F}^{-} \\
(\mathrm{mg} / \mathrm{L})\end{array}$ & $\begin{array}{l}\mathrm{Cl}^{-} \\
(\mathrm{mg} / \mathrm{L})\end{array}$ & $\begin{array}{l}\mathrm{NO}_{3}^{-} \\
(\mathrm{mg} / \mathrm{L})\end{array}$ & $\begin{array}{l}\mathrm{SO}_{4}^{2-} \\
(\mathrm{mg} / \mathrm{L})\end{array}$ & $\begin{array}{l}\mathrm{NO}_{2}^{-} \\
(\mathrm{mg} / \mathrm{L})\end{array}$ & $\begin{array}{l}\mathrm{Br}^{-} \\
(\mathrm{mg} / \mathrm{L})\end{array}$ \\
\hline 1 & 0.23 & 5.79 & 26.22 & 43.67 & $<0.05$ & $<0.2$ \\
\hline 2 & 0.26 & 5.39 & 26.28 & 42.10 & $<0.05$ & $<0.2$ \\
\hline 3 & 0.23 & 5.26 & 25.38 & 42.72 & $<0.05$ & $<0.2$ \\
\hline 4 & 0.22 & 5.25 & 27.06 & 43.34 & $<0.05$ & $<0.2$ \\
\hline 5 & 0.21 & 5.19 & 26.35 & 41.96 & $<0.05$ & $<0.2$ \\
\hline 6 & 0.21 & 5.12 & 26.50 & 41.45 & $<0.05$ & $<0.2$ \\
\hline 7 & 0.22 & 5.11 & 26.70 & 41.21 & $<0.05$ & $<0.2$ \\
\hline 8 & 0.23 & 5.01 & 26.38 & 40.25 & $<0.05$ & $<0.2$ \\
\hline 9 & 0.21 & 5.18 & 26.81 & 40.91 & $<0.05$ & $<0.2$ \\
\hline 10 & 0.24 & 4.89 & 25.78 & 39.96 & $<0.05$ & $<0.2$ \\
\hline 11 & 0.26 & 4.78 & 26.09 & 40.18 & $<0.05$ & $<0.2$ \\
\hline 12 & 0.28 & 4.94 & 26.40 & 39.83 & $<0.05$ & $<0.2$ \\
\hline 13 & 0.23 & 4.85 & 25.89 & 40.38 & $<0.05$ & $<0.2$ \\
\hline 14 & 0.24 & 4.98 & 26.24 & 40.26 & $<0.05$ & $<0.2$ \\
\hline 15 & 0.22 & 4.84 & 26.40 & 41.38 & $<0.05$ & $<0.2$ \\
\hline 16 & 0.20 & 4.91 & 26.20 & 41.58 & $<0.05$ & $<0.2$ \\
\hline 17 & 0.18 & 4.79 & 25.76 & 40.29 & $<0.05$ & $<0.2$ \\
\hline 18 & 0.19 & 4.96 & 25.79 & 42.05 & $<0.05$ & $<0.2$ \\
\hline 19 & 0.27 & 4.91 & 25.77 & 41.28 & $<0.05$ & $<0.2$ \\
\hline 20 & 0.20 & 4.95 & 26.05 & 41.82 & $<0.05$ & $<0.2$ \\
\hline 21 & 0.22 & 4.92 & 25.86 & 42.49 & $<0.05$ & $<0.2$ \\
\hline 22 & 0.23 & 5.18 & 26.25 & 42.62 & $<0.05$ & $<0.2$ \\
\hline 23 & 0.24 & 4.96 & 25.43 & 42.39 & $<0.05$ & $<0.2$ \\
\hline 24 & 0.21 & 5.04 & 25.57 & 43.20 & $<0.05$ & $<0.2$ \\
\hline
\end{tabular}




\begin{tabular}{|l|l|l|l|l|l|l|}
\hline 25 & 0.24 & 5.07 & 25.83 & 42.77 & $<0.05$ & $<0.2$ \\
\hline 26 & 0.21 & 4.98 & 25.74 & 42.47 & $<0.05$ & $<0.2$ \\
\hline 27 & 0.23 & 5.08 & 25.05 & 42.58 & $<0.05$ & $<0.2$ \\
\hline 28 & 0.26 & 5.15 & 25.53 & 42.66 & $<0.05$ & $<0.2$ \\
\hline 29 & 0.21 & 5.19 & 25.19 & 43.05 & $<0.05$ & $<0.2$ \\
\hline 30 & 0.26 & 5.13 & 25.55 & 42.63 & $<0.05$ & $<0.2$ \\
\hline 31 & 0.18 & 5.03 & 25.32 & 42.51 & $<0.05$ & $<0.2$ \\
\hline 32 & 0.20 & 5.10 & 24.84 & 42.38 & $<0.05$ & $<0.2$ \\
\hline 33 & 0.20 & 5.20 & 25.14 & 42.76 & $<0.05$ & $<0.2$ \\
\hline 34 & 0.20 & 5.14 & 24.49 & 42.41 & $<0.05$ & $<0.2$ \\
\hline 35 & 0.23 & 5.35 & 25.65 & 43.15 & $<0.05$ & $<0.2$ \\
\hline 36 & 0.24 & 5.34 & 25.43 & 42.59 & $<0.05$ & $<0.2$ \\
\hline
\end{tabular}

Appendix Table C4: Time series water sample metal(loid) data from Maoshuikeng (location \#294).

\begin{tabular}{|l|l|l|l|l|l|l|}
\hline Sample \# & $\begin{array}{l}\mathrm{Ca}^{2+} \\
(\mathrm{mg} / \mathrm{L})\end{array}$ & $\begin{array}{l}\mathrm{K}^{+} \\
(\mathrm{mg} / \mathrm{L})\end{array}$ & $\begin{array}{l}\mathrm{Mg}^{2+} \\
(\mathrm{mg} / \mathrm{L})\end{array}$ & $\begin{array}{l}\mathrm{Na}^{+} \\
(\mathrm{mg} / \mathrm{L})\end{array}$ & $\begin{array}{l}\mathrm{SiO}_{2}{ }^{2+} \\
(\mathrm{mg} / \mathrm{L})\end{array}$ & $\begin{array}{l}\mathrm{Sr}^{2+} \\
(\mathrm{mg} / \mathrm{L})\end{array}$ \\
\hline 1 & 66.12 & 3.21 & 16.65 & 3.43 & 4.60 & 0.88 \\
\hline 2 & 64.57 & 3.12 & 16.36 & 3.06 & 4.64 & 0.86 \\
\hline 3 & 64.65 & 3.08 & 16.31 & 3.11 & 4.61 & 0.85 \\
\hline 4 & 64.97 & 3.11 & 16.68 & 3.11 & 4.66 & 0.85 \\
\hline 5 & 65.48 & 2.99 & 16.26 & 3.05 & 4.59 & 0.83 \\
\hline 6 & 65.25 & 2.95 & 16.32 & 3.02 & 4.64 & 0.83 \\
\hline 7 & 67.89 & 2.98 & 16.38 & 2.90 & 4.60 & 0.84 \\
\hline 8 & 64.80 & 2.90 & 16.32 & 2.69 & 4.53 & 0.80 \\
\hline 9 & 65.37 & 2.93 & 16.34 & 2.58 & 4.49 & 0.78 \\
\hline 10 & 64.79 & 2.95 & 16.28 & 2.78 & 4.52 & 0.78 \\
\hline 11 & 65.75 & 3.01 & 16.42 & 2.92 & 4.62 & 0.78 \\
\hline
\end{tabular}




\begin{tabular}{|c|c|c|c|c|c|c|}
\hline 12 & 64.08 & 2.91 & 16.28 & 2.81 & 4.61 & 0.76 \\
\hline 13 & 65.03 & 2.99 & 16.66 & 2.85 & 4.68 & 0.78 \\
\hline 14 & 64.44 & 2.99 & 16.57 & 2.87 & 4.58 & 0.77 \\
\hline 15 & 64.26 & 2.96 & 16.56 & 2.97 & 4.67 & 0.78 \\
\hline 16 & 64.36 & 3.00 & 16.68 & 2.95 & 4.65 & 0.76 \\
\hline 17 & 64.22 & 3.06 & 16.81 & 3.02 & 4.64 & 0.78 \\
\hline 18 & 64.44 & 3.08 & 16.99 & 3.01 & 4.68 & 0.78 \\
\hline 19 & 64.68 & 3.10 & 17.14 & 3.00 & 4.73 & 0.79 \\
\hline 20 & 64.31 & 3.07 & 16.92 & 3.05 & 4.76 & 0.79 \\
\hline 21 & 66.02 & 3.07 & 17.06 & 2.95 & 4.76 & 0.79 \\
\hline 22 & 64.99 & 3.04 & 17.01 & 2.94 & 4.72 & 0.79 \\
\hline 23 & 65.78 & 3.07 & 17.10 & 2.99 & 4.79 & 0.78 \\
\hline 24 & 66.06 & 3.06 & 17.06 & 3.01 & 4.89 & 0.80 \\
\hline 25 & 65.40 & 3.08 & 17.13 & 2.95 & 4.72 & 0.79 \\
\hline 26 & 69.38 & 3.04 & 16.92 & 2.90 & 4.76 & 0.79 \\
\hline 27 & 67.87 & 3.02 & 16.93 & 2.94 & 4.61 & 0.79 \\
\hline 28 & 65.17 & 3.06 & 17.12 & 3.07 & 4.71 & 0.80 \\
\hline 29 & 64.26 & 2.96 & 16.61 & 3.02 & 4.59 & 0.80 \\
\hline 30 & 64.77 & 3.03 & 17.16 & 2.90 & 4.74 & 0.80 \\
\hline 31 & 65.19 & 2.96 & 16.75 & 2.98 & 4.65 & 0.79 \\
\hline 32 & 65.80 & 3.18 & 17.06 & 3.13 & 4.61 & 0.81 \\
\hline 33 & 65.34 & 3.00 & 16.77 & 3.02 & 4.65 & 0.81 \\
\hline 34 & 66.63 & 3.03 & 16.95 & 3.02 & 4.69 & 0.82 \\
\hline 35 & 67.47 & 3.01 & 16.92 & 3.07 & 4.67 & 0.82 \\
\hline 36 & 64.86 & 3.05 & 16.74 & 3.04 & 4.58 & 0.82 \\
\hline
\end{tabular}


Appendix Table C5: Time series water sample calculated values from Maoshuikeng (location \#294). CBE = Charge Balance \% Error

\begin{tabular}{|l|l|l|l|l|l|l|l|}
\hline Sample \# & $\mathrm{Mg} / \mathrm{Ca}$ & $\mathrm{SI}_{\text {calcite }}$ & SIdolomite & SI strontianite & SIgypsum & SIcelestite & $\mathrm{CBE}$ \\
\hline 1 & 0.42 & -0.28 & -0.85 & -1.70 & -1.95 & -2.10 & 1.91 \\
\hline 2 & 0.42 & -0.26 & -0.81 & -1.66 & -1.97 & -2.14 & 1.18 \\
\hline 3 & 0.42 & -0.47 & -1.25 & -1.88 & -1.96 & -2.13 & 0.93 \\
\hline 4 & 0.42 & -0.53 & -1.36 & -1.95 & -1.96 & -2.13 & 1.23 \\
\hline 5 & 0.41 & -0.47 & -1.26 & -1.89 & -1.97 & -2.16 & 1.32 \\
\hline 6 & 0.41 & -0.47 & -1.25 & -1.89 & -1.97 & -2.16 & 1.34 \\
\hline 7 & 0.40 & -0.39 & -1.12 & -1.83 & -1.96 & -2.16 & 2.32 \\
\hline 8 & 0.42 & -0.40 & -1.11 & -1.83 & -1.99 & -2.19 & 0.79 \\
\hline 9 & 0.41 & -0.43 & -1.18 & -1.88 & -1.98 & -2.19 & 1.35 \\
\hline 10 & 0.41 & -0.29 & -0.89 & -1.73 & -1.99 & -2.20 & 1.68 \\
\hline 11 & 0.41 & 0.03 & -0.24 & -1.42 & -1.99 & -2.20 & 2.32 \\
\hline 12 & 0.42 & -0.33 & -0.95 & -1.79 & -2.00 & -2.21 & 0.49 \\
\hline 13 & 0.42 & -0.08 & -0.43 & -1.54 & -1.99 & -2.19 & 1.43 \\
\hline 14 & 0.42 & -0.17 & -0.64 & -1.63 & -1.99 & -2.20 & 0.73 \\
\hline 15 & 0.42 & -0.25 & -0.79 & -1.69 & -1.98 & -2.18 & 1.21 \\
\hline 16 & 0.43 & -0.28 & -0.86 & -1.73 & -1.98 & -2.19 & 0.57 \\
\hline 17 & 0.43 & -0.34 & -0.98 & -1.78 & -1.99 & -2.20 & 1.53 \\
\hline 18 & 0.43 & -0.35 & -1.00 & -1.79 & -1.97 & -2.18 & 0.90 \\
\hline 19 & 0.44 & -0.36 & -1.01 & -1.80 & -1.98 & -2.19 & 1.31 \\
\hline 20 & 0.43 & -0.42 & -1.14 & -1.85 & -1.97 & -2.18 & 0.57 \\
\hline 21 & 0.43 & -0.36 & -1.03 & -1.81 & -1.96 & -2.18 & 1.22 \\
\hline 22 & 0.43 & -0.30 & -0.91 & -1.74 & -1.96 & -2.17 & 0.43 \\
\hline 23 & 0.43 & -0.33 & -0.96 & -1.78 & -1.96 & -2.18 & 1.00 \\
\hline 24 & 0.43 & -0.29 & -0.89 & -1.73 & -1.95 & -2.16 & 0.92 \\
\hline 25 & 0.43 & -0.30 & -0.91 & -1.75 & -1.96 & -2.17 & 1.06 \\
\hline
\end{tabular}




\begin{tabular}{|l|l|l|l|l|l|l|l|}
\hline 26 & 0.40 & -0.19 & -0.72 & -1.66 & -1.94 & -2.18 & 2.41 \\
\hline 27 & 0.41 & -0.29 & -0.90 & -1.74 & -1.95 & -2.18 & 1.92 \\
\hline 28 & 0.43 & -0.28 & -0.86 & -1.71 & -1.96 & -2.17 & 0.59 \\
\hline 29 & 0.43 & -0.26 & -0.82 & -1.68 & -1.96 & -2.16 & -0.63 \\
\hline 30 & 0.44 & -0.22 & -0.73 & -1.65 & -1.97 & -2.17 & 0.33 \\
\hline 31 & 0.42 & -0.23 & -0.77 & -1.67 & -1.96 & -2.17 & 0.57 \\
\hline 32 & 0.43 & -0.28 & -0.86 & -1.72 & -1.96 & -2.17 & 0.95 \\
\hline 33 & 0.42 & -0.23 & -0.77 & -1.66 & -1.96 & -2.16 & 0.18 \\
\hline 34 & 0.42 & -0.15 & -0.62 & -1.59 & -1.96 & -2.16 & 1.47 \\
\hline 35 & 0.41 & -0.16 & -0.62 & -1.60 & -1.95 & -2.15 & 1.45 \\
\hline 36 & 0.43 & -0.10 & -0.50 & -1.52 & -1.97 & -2.16 & -4.09 \\
\hline
\end{tabular}

Appendix Table C6: Time series water sample isotope values from Maoshuikeng (location \#294).

\begin{tabular}{|l|l|l|l|l|l|l|}
\hline Sample \# & $\begin{array}{l}\delta^{13} \text { CDIC } \\
(\% \text { PDB })\end{array}$ & SD & $\begin{array}{l}\delta^{2} \mathrm{H}(\% \circ \\
\text { VSMOW) }\end{array}$ & SD & $\begin{array}{l}\delta^{18} \text { O (\%o } \\
\text { VSMOW) }\end{array}$ & SD \\
\hline 1 & -12.20 & 0.024 & -51.74 & 0.07 & -7.74 & 0.03 \\
\hline 2 & -12.03 & 0.24 & -51.39 & 0.53 & -7.72 & 0.07 \\
\hline 3 & -11.80 & 0.026 & -51.64 & 0.36 & -7.76 & 0.02 \\
\hline 4 & -11.55 & 0.029 & -51.61 & 0.19 & -7.8 & 0.03 \\
\hline 5 & -11.90 & 0.012 & -51.35 & 0.24 & -7.7 & 0.03 \\
\hline 6 & -11.97 & 0.029 & -51.41 & 0.07 & -7.7 & 0.03 \\
\hline 7 & -11.99 & 0.006 & -51.55 & 0.17 & -7.65 & 0.05 \\
\hline 8 & -11.99 & 0.024 & -51.5 & 0.33 & -7.6 & 0.04 \\
\hline 9 & -12.13 & 0.02 & -52.28 & 0.12 & -7.81 & 0.03 \\
\hline 10 & -11.69 & 0.032 & -52.83 & 0.61 & -7.9 & 0.02 \\
\hline 11 & -12.04 & 0.021 & -52.98 & 0.17 & -7.93 & 0.04 \\
\hline 12 & -11.86 & 0.034 & -53.03 & 0.96 & -7.98 & 0.07 \\
\hline
\end{tabular}




\begin{tabular}{|c|c|c|c|c|c|c|}
\hline 13 & -12.03 & 0.019 & -52.53 & 0.26 & -7.91 & 0.04 \\
\hline 14 & -11.97 & 0.028 & -52.86 & 0.68 & -7.92 & 0.09 \\
\hline 15 & -12.34 & 0.016 & -52.29 & 0.17 & -7.83 & 0.03 \\
\hline 16 & -12.08 & 0.041 & -52.35 & 1.09 & -7.79 & 0.11 \\
\hline 17 & -11.57 & 0.023 & -52.38 & 0.24 & -7.81 & 0.06 \\
\hline 18 & -12.06 & 0.025 & -52.5 & 0.16 & -7.81 & 0.05 \\
\hline 19 & -12.08 & 0.022 & -52.4 & 0.11 & -7.82 & 0.04 \\
\hline 20 & -12.13 & 0.012 & -52.94 & 0.67 & -7.87 & 0.06 \\
\hline 21 & -11.97 & 0.019 & -52.57 & 0.59 & -7.87 & 0.04 \\
\hline 22 & -11.67 & 0.046 & -52.6 & 0.34 & -7.87 & 0.05 \\
\hline 23 & -12.18 & 0.086 & -52.71 & 0.15 & -7.93 & 0.04 \\
\hline 24 & -12.02 & 0.055 & -52.74 & 0.16 & -7.87 & 0.02 \\
\hline 25 & -12.00 & 0.032 & -52.82 & 0.35 & -7.88 & 0.03 \\
\hline 26 & -12.08 & 0.052 & -52.65 & 0.19 & -7.71 & 0.04 \\
\hline 27 & -12.19 & 0.021 & -52.58 & 0.5 & -7.72 & 0.09 \\
\hline 28 & -12.01 & 0.008 & -52.64 & 0.15 & -7.76 & 0.05 \\
\hline 29 & \multicolumn{2}{|c|}{ Broken vial } & -52.68 & 0.18 & -7.8 & 0.07 \\
\hline 30 & -12.01 & 0.032 & -53.38 & 0.2 & -7.84 & 0.03 \\
\hline 31 & -12.08 & 0.043 & -53.11 & 0.29 & -7.93 & 0.06 \\
\hline 32 & -12.22 & 0.01 & -52.89 & 0.19 & -7.9 & 0.03 \\
\hline 33 & -11.94 & 0.015 & -52.74 & 0.41 & -7.91 & 0.06 \\
\hline 34 & -12.01 & 0.008 & -52.76 & 0.1 & -7.89 & 0.03 \\
\hline 35 & -11.89 & 0.019 & -52.33 & 0.28 & -7.81 & 0.05 \\
\hline 36 & -11.91 & 0.024 & -52.2 & 0.33 & -7.8 & 0.05 \\
\hline
\end{tabular}


Appendix Table C7: Time series field parameter data from Daxing (location \#121). Dates and times are local. HAI $=$ Hours after injection

\begin{tabular}{|l|l|l|l|l|l|l|}
\hline Sample \# & Date and Time & HAI & $\begin{array}{l}\mathrm{EC} \\
(\mathrm{mS} / \mathrm{cm})\end{array}$ & $\mathrm{T}\left({ }^{\circ} \mathrm{C}\right)$ & $\mathrm{pH}$ & $\begin{array}{l}\text { Alk (mg/L } \\
\text { CaCO3 })\end{array}$ \\
\hline 0 & $6 / 23 / 1813: 00$ & 0.00 & --- & --- & --- & --- \\
\hline 1 & $6 / 23 / 1813: 50$ & 0.83 & 374 & 20.0 & 6.939 & 139 \\
\hline 2 & $6 / 24 / 1813: 00$ & 24.00 & 469 & 19.23 & 7.160 & 166 \\
\hline 3 & $6 / 25 / 1814: 55$ & 49.92 & 510 & 19.03 & 7.124 & 174 \\
\hline
\end{tabular}

Appendix Table C8: Time series water sample anion data from Daxing (location \#121).

\begin{tabular}{|l|l|l|l|l|l|l|}
\hline Sample \# & $\begin{array}{l}\mathrm{F}^{-} \\
(\mathrm{mg} / \mathrm{L})\end{array}$ & $\begin{array}{l}\mathrm{Cl}^{-} \\
(\mathrm{mg} / \mathrm{L})\end{array}$ & $\begin{array}{l}\mathrm{NO}_{3}^{-} \\
(\mathrm{mg} / \mathrm{L})\end{array}$ & $\begin{array}{l}\mathrm{SO}_{4}^{2-} \\
(\mathrm{mg} / \mathrm{L})\end{array}$ & $\begin{array}{l}\mathrm{NO}_{2}^{-} \\
(\mathrm{mg} / \mathrm{L})\end{array}$ & $\begin{array}{l}\mathrm{Br}^{-} \\
(\mathrm{mg} / \mathrm{L})\end{array}$ \\
\hline 1 & 0.336 & 6.050 & 19.618 & 32.088 & 0.116 & $<0.2$ \\
\hline 2 & 0.276 & 6.451 & 29.586 & 66.004 & $<0.05$ & $<0.2$ \\
\hline 3 & 0.288 & 7.602 & 28.755 & 76.029 & $<0.05$ & $<0.2$ \\
\hline
\end{tabular}

Appendix Table C9: Time series water sample metal(loid) data from Daxing (location \#121).

\begin{tabular}{|l|l|l|l|l|l|l|}
\hline Sample \# & $\begin{array}{l}\mathrm{Ca}^{2+} \\
(\mathrm{mg} / \mathrm{L})\end{array}$ & $\begin{array}{l}\mathrm{K}^{+} \\
(\mathrm{mg} / \mathrm{L})\end{array}$ & $\begin{array}{l}\mathrm{Mg}^{2+} \\
(\mathrm{mg} / \mathrm{L})\end{array}$ & $\begin{array}{l}\mathrm{Na}^{+} \\
(\mathrm{mg} / \mathrm{L})\end{array}$ & $\begin{array}{l}\mathrm{SiO}_{2}{ }^{0} \\
(\mathrm{mg} / \mathrm{L})\end{array}$ & $\begin{array}{l}\mathrm{Sr}^{2+} \\
(\mathrm{mg} / \mathrm{L})\end{array}$ \\
\hline 1 & 58.64 & 4.11 & 9.89 & 2.71 & 4.268 & 0.880 \\
\hline 2 & 78.79 & 4.38 & 14.18 & 3.85 & 5.603 & 1.398 \\
\hline 3 & 85.63 & 4.35 & 16.41 & 4.23 & 5.712 & 1.670 \\
\hline
\end{tabular}


Appendix Table C10: Time series water sample calculated values from Daxing (location \#121). CBE = Charge Balance \% Error

\begin{tabular}{|l|l|l|l|l|l|l|l|}
\hline Sample \# & $\mathrm{Mg} / \mathrm{Ca}$ & SIcalcite & SIdolomite $_{\text {S }}$ & SI $_{\text {strontianite }}$ & $\mathrm{SI}_{\text {gypsum }}$ & $\mathrm{SI}_{\text {celestite }}$ & $\mathrm{CBE}$ \\
\hline 1 & 0.28 & -0.57 & -2.09 & -1.92 & -1.64 & -2.21 & 0.36 \\
\hline 2 & 0.30 & -0.20 & -1.71 & -1.47 & -0.87 & -1.76 & 0.44 \\
\hline 3 & 0.32 & -0.19 & -1.63 & -1.42 & -0.83 & -1.64 & 1.85 \\
\hline
\end{tabular}

Appendix Table C11: Time series water sample isotope values from Daxing (location $\# 121)$.

\begin{tabular}{|l|l|l|l|l|l|l|}
\hline Sample \# & $\begin{array}{l}\delta^{13} \text { CDIC } \\
\text { (\%o PDB) }\end{array}$ & SD & $\begin{array}{l}\delta^{2} \mathrm{H}(\% \circ \\
\text { VSMOW) }\end{array}$ & SD & $\begin{array}{l}\delta^{18} \mathrm{O}(\% \circ \\
\text { VSMOW) }\end{array}$ & SD \\
\hline 1 & -12.82 & 0.025 & -49.86 & 0.27 & -7.09 & 0.02 \\
\hline 2 & -13.48 & 0.03 & -51.32 & 0.3 & -7.62 & 0.05 \\
\hline 3 & -13.49 & 0.028 & -51.13 & 0.32 & -7.67 & 0.02 \\
\hline
\end{tabular}




\section{REFERENCES}

Agriculture, Chinese Ministry of, 2015, China targets zero growth in chemical fertiliser use in 2020, Volume 2019, The Business Times: Government and Economy.

Buckerfield, S. J., Waldron, S., Quilliam, R. S., Naylor, L. A., Li, S., and Oliver, D. M., 2019, How can we improve understanding of faecal indicator dynamics in karst systems under changing climatic, population, and land use stressors? - Research opportunities in SW China: Science of the Total Environment, v. 646, p. 438-447.

Cao, J., Yuan, D., Tong, L., Mallik, A., Yang, H., and Huang, F., 2015, An overview of karst ecosystem in southwest China: Current state and future management: Journal of Resources and Ecology, v. 6, no. 4, p. 247-256.

Chadwick, D., Wei, J., Yan'an, T., Guanghui, Y., Qirong, S., and Qing, C., 2015, Improving manure nutrient management towards sustainable agricultural intensification in China: Agriculture, Ecosystems and Environment, v. 209, p. 3446.

Chen, X., Zhang, Y. F., Zhou, Y. Y., and Zhang, Z. C., 2013, Analysis of hydrogeological parameters and numerical modeling groundwater in a karst watershed, southwest China: Carbonates and Evaporites, v. 28, no. 1-2, p. 89-94.

Chen, X., Zhang, Z., Soulsby, C., Cheng, Q., Binley, A., Jiang, R., and Tao, M., 2018, Characterizing the heterogeneity of karst critical zone and its hydrological function: An integrated approach: Hydrological Processes, v. 32, p. 2932-2946.

Currens, J. C., 2013, Kentucky Geological Survey Procedures for Groundwater Tracing Using Fluorescent Dyes: Kentucky Geological Survey, Series XII, Information Circular 26.

Ford, D. C., and Williams, P. W., 2007, Karst Hydrogeology and Geomorphology, Chichester, England, John Wiley \& Sons.

Fritz, P., Cherry, J. A., Sklash, M., and Weyer, K. U., 1976, Storm runoff analysis using environmental isotopes and major ions. In Interpretation of Environmental Isotope and Hydrochemical Data in Groundwater Hydrology, International Atomic Energy Agency, p. 111-130.

Hu, X. J., Chen, B., Hu, X. H., and He, G. H., 2001, Study on the model of rational land use in the karst areas of the Houzhai River Basin. (In Chinese with English abstract.): Carsologica Sinica, v. 20, p. 305-309.

Lakey, B., and Krothe, N. C., 1996, Stable isotopic variation of storm discharge from a perennial karst spring, Indiana: Water Resources Research, v. 32, no. 3, p. 721731.

Langmuir, D., 1971, The geochemistry of some carbonate ground waters in central Pennsylvania: Geochimica et Cosmochimica Acta, v. 35, p. 1023-1045.

Li, S.-L., Liu, C.-Q., Li, J., Lang, Y.-C., Ding, H., and Li, L. B., 2010, Geochemistry of dissolved inorganic carbon and carbonate weathering in a small typical karstic catchment of Southwest China: Isotopic and chemical constraints: Chemical Geology, v. 277, no. 3-4, p. 301-309. 
Lian, Y., You, G., Lin, K., Jiang, Z., Zhang, C., and Qin, X., 2015, Characteristics of climate change in southwest China karst region and their potential environmental impacts: Environmental Earth Sciences, v. 74, p. 937-944.

Liu, L. H., Shu, L. C., Chen, X. H., and Oromo, T., 2010, The hydrologic function and behavior of the Houzhai underground river basin, Guizhou Province, southwestern China: Hydrogeology Journal, v. 18, no. 2, p. 509-518.

Liu, Z. H., Groves, C., Yuan, D. X., Meiman, J., Jiang, G. H., He, S. Y., and Li, Q. A., 2004, Hydrochemical variations during flood pulses in the southwest China peak cluster karst: impacts of CaCO3-H2O-CO2 interactions: Hydrological Processes, v. 18 , no. 13 , p. 2423-2437.

Musgrove, M., and Banner, J. L., 2004, Controls on the spatial and temporal variability of vadose dripwater geochemistry: Edwards Aquifer, central Texas: Geochimica et Cosmochimica Acta, v. 68, no. 5, p. 1007-1020.

O’Leary, M. H., 1988, Carbon isotopes in photosynthesis: Bioscience, v. 38, no. 5, p. 328-336.

Scanlon, B. R., 1990, Relationships between groundwater contamination and major-ion chemistry in a karst aquifer: Journal of Hydrology, v. 119, p. 271-291.

Sheppard, S. M., and Schwarcz, H. P., 1970, Fractionation of carbon and oxygen isotopes and magnesium between coexisting calcite and dolomite: Contributions to Mineralogy and Petrology, v. 26, p. 161.

Shuster, E. T., and White, W. W., 1971, Seasonal fluctuations in the chemistry of limestone springs: a possible means for characterizing carbonate aquifers: Journal of Hydrology, v. 14, p. 93-128.

Wang, L. C., and Zhang, Y. Z., 2001, Karst conduit flow and its hydrodynamic characteristics - Houzhai River drainage basin in Puding, Guizhou, China as an example: Chinese Science Bulletin, v. 46, p. 45-51.

White, W. B., 1988, Geomorphology and Hydrology of Karst Terrains, New York, Oxford University Press.

Yan, J. H., Li, J. M., Ye, Q., and Li, K., 2012, Concentrations and exports of solutes from surface runoff in Houzhai Karst Basin, southwest China: Chemical Geology, v. 304, p. 1-9.

Yang, R., Liu, Z. H., Zeng, C., and Zhao, M., 2012, Response of epikarst hydrochemical changes to soil CO2 and weather conditions at Chenqi, Puding, SW China: Journal of Hydrology, v. 468, p. 151-158.

Yang, Y., 2001, A study of the structure of karst aquifer medium and the groundwater flow in Houzhai underground river basin: Carsologica Sinica, v. 20, no. 1, p. 1720.

Yu, J., and Zhang, H., 1988, Karst geomorphology in Puding, Guizhou Province: Carsologica Sinica, v. 7, no. 2, p. 163-172.

Yue, F.-J., Li, S.-L., Zhong, J., and Liu, J., 2018, Evaluation of factors driving seasonal nitrate variations in surface and underground systems of a karst catchment: Vadose Zone Journal, v. 17, no. 1.

Zhang, R. R., Shu, L. C., Zhu, J. T., Yu, Z. B., and Jiang, P., 2016, Storage and drainage characteristics of a highly heterogeneous karst aquifer in Houzhai basin: Groundwater, v. 54, no. 6, p. 878-887. 
Zhang, Z., Chen, X., Cheng, Q., and Soulsby, C., 2019, Storage dynamics, hydrological connectivity and flux ages in a karst catchment: conceptual modelling using stable isotopes: Hydrology and Earth System Sciences, v. 23, p. 51-71.

Zhang, Z., Chen, X., and Soulsby, C., 2017, Catchment-scale conceptual modelling of water and solute transport in the dual flow system of the karst critical zone: Hydrological Processes, v. 31, no. 19, p. 3421-3436. 
VITA

Joshua M. Barna

Education

B.S. Geology with Honors, Magna Cum Laude (2017)

Bucknell University

Experience

Graduate Teaching Assistant (2017-2019)

Department of Earth and Environmental Sciences

University of Kentucky, Lexington, KY 40506

Undergraduate Teaching Assistant (2016-2017)

Department of Geology and Environmental Geosciences

Bucknell University, Lewisburg, PA 17837

Awards

Teaching Assistant Award for Excellence in Student Teaching in Geology (2016)

The Richard P. Nickelsen Prize (2017) 